\title{
Four Days that Transformed Spain 11-M Impact on Memory Recovery Examined through the Lens of Duality
}

\author{
Thomas J. Divins
}

Follow this and additional works at: https://researchrepository.wvu.edu/etd

\section{Recommended Citation}

Divins, Thomas J., "Four Days that Transformed Spain 11-M Impact on Memory Recovery Examined through the Lens of Duality" (2016). Graduate Theses, Dissertations, and Problem Reports. 5501. https://researchrepository.wvu.edu/etd/5501

This Thesis is protected by copyright and/or related rights. It has been brought to you by the The Research Repository @ WVU with permission from the rights-holder(s). You are free to use this Thesis in any way that is permitted by the copyright and related rights legislation that applies to your use. For other uses you must obtain permission from the rights-holder(s) directly, unless additional rights are indicated by a Creative Commons license in the record and/ or on the work itself. This Thesis has been accepted for inclusion in WVU Graduate Theses, Dissertations, and Problem Reports collection by an authorized administrator of The Research Repository @ WVU. For more information, please contact researchrepository@mail.wvu.edu. 


\title{
Four Days that Transformed Spain
}

\section{1-M Impact on Memory Recovery Examined through the \\ Lens of Duality}

\author{
Thomas J. Divins
}

A Thesis Submitted to the Eberly College of Arts and Sciences at West Virginia University

In partial fulfillment of the requirements for the Degree of

Master of Arts in Modern European History

James Siekmeier, Ph.D., Chair

Joshua Arthurs, Ph.D., Advisor

Tamba M'bayo, Ph.D.

Department of History

Morgantown, West Virginia
2016

Keywords: 11-M, two Spains, Spanish Genocide, Spanish Memory Recovery, Spanish Amnesty, Spanish Silencing

Copyright 2016 Thomas J. Divins 


\title{
ABSTRACT \\ Four Days that Transformed Spain: 11-M Impact on Memory Recovery Examined through the Lens of Duality
}

\author{
Thomas J. Divins
}

This thesis studies the controversial aftermath of the Madrid terrorist attack of March 11, 2004 and how it impacted the history of memory and silence in Spain since the Spanish Civil War. The terrorist attack had surprising and significant short-term political impacts, which have been well documented by historians, political scientists, and journalists. However, surveying the attack aftermath through the lens of the history of duality in Spain has been less studied. The "lens of duality" is the viewpoint that Spain's history in the twentieth and twenty-first centuries can be explained as a clash between deeply-divided sectors within society which created a sense of duality. This duality has been exhibited not only in society, but also in politics, and came to the forefront of conversation following the Madrid train bombings. The thesis offers a new perspective from the viewpoint of the history of memory and silence regarding the controversies following the terrorist attack and its effect on society in Spain.

This thesis is divided into four parts: 1) introduction and duality of Spain; 2) controversies following the Madrid terrorist attack; 3) impact on Spanish historical memory, silence, and society, and 4) conclusion and recommendations.

One of the purposes of this thesis is to demonstrate that the Madrid terrorist attack and its aftermath intensified the recovery of Spanish Civil War memories and the breaking of post-Civil War silence in Spain. Another purpose is to present a theory for the surprising response of the Spanish people to the 11-M crisis. 


\section{ACKNOWLEDGEMENTS}

I would like to express my sincere thanks to my advisor Dr. Joshua Arthurs for his patience and encouragement during my graduate studies. I thank Dr. James Siekmeier and Dr. Tamba M'bayo for serving on my thesis committee and offering their advice and support. I also thank my parents for their support and assistance with my proofreading and my friends for their support and understanding during the writing process.

I am grateful to West Virginia University and the State of West Virginia for financial support. 


\section{TABLE OF CONTENTS}

ABSTRACT

ACKNOWLEDGEMENTS $\quad$ iii

$\begin{array}{ll}\text { INTRODUCTION } & 1\end{array}$

Historical Background of Spanish Duality 1

11-M Attacks 4

Research Questions $\quad 5$

$\begin{array}{ll}\text { Thesis Objectives } & 6\end{array}$

$\begin{array}{ll}\text { Theory and Definitions Historiography } & 7\end{array}$

CONTROVERSIAL AFTERMATH OF 11-M 17

Immediate Aftermath Timeline 17

11-M Historiography 25

$\begin{array}{ll}\text { Controversies } & 31\end{array}$

Election Outcome $\quad 31$

Protestors' Motivations 36

$\begin{array}{ll}\text { Perpetrators } & 43\end{array}$

Terrorists’ Motivations $\quad 49$

Aftermath Connection to Duality of Spain 51

RECOVERY OF MEMORY AND BREAKING OF SILENCE 54

Relevancy of "Luz Blanca” Poem 55

Civil War Overview $\quad 55$

Amnesty and Silence $\quad 56$

Breaking of Silence $\quad 64$

$\begin{array}{ll}\text { 11-M Aftermath } & 68\end{array}$

Two Spains Reincarnation $\quad 72$

$\begin{array}{ll}\text { SUMMARY AND CONCLUSIONS } & 74\end{array}$

RECOMMENDATIONS $\quad 80$

$\begin{array}{ll}\text { BIBLIOGRAPHY } & 84\end{array}$ 


\section{Four Days that Transformed Spain: 11-M Impact on Memory Recovery Examined through the Lens of Duality}

\section{INTRODUCTION}

Ya hay un español que quiere

vivir y a vivir empieza,

entre una España que muere

y otra España que bosteza.

Españolito que vienes

al mundo, te guarde Dios:

Una de las dos Españas

ha de helarte el corazón.

There is now a Spaniard who wants

to live, and is beginning to live,

between a Spain that dies

and a Spain that yawns.

Little Spaniard who comes into

this world, God help you!

One of the two Spains

will freeze your heart.

Antonio Machado, Untitled poem, but widely known as The Two Spains, $1913^{1}$

Historical Background of Spanish Duality

The concept of "two Spains" has been a persistent theme in Spanish identity since at least 1836 when Mariano José de Larra wrote an article about a divided Spain, titled "El día de

\footnotetext{
${ }^{1}$ Richard Gunther, José Ramón Montero, and Joan Botella, Democracy in Modern Spain (New Haven: Yale University Press, 2004), 64.
} 
Difuntos de 1836" (All Soul's Day 1836). ${ }^{2}$ Just before the beginning of the twentieth century, the Spanish-American War destroyed Spanish colonialism and dreams of empire with farreaching political and societal impact. Subsequently, a debate arose between conservatives and liberals to create a vision and common destiny for Spain. Conservatives believed that there was a need to regenerate Spain along traditional values and 'hispanicity' based on the Catholic monarchy and the Reconquista. In contrast, liberals blamed the Catholic Church, the monarchy, and landowners for repressing Spain and for failing to modernize, hence the defeat to the modern United States Navy. They were in essence arguing that Spain had many remnants of feudal society. The debate failed to create a consensus vision and destiny, which reinforced a divided Spain, and also failed to construct a coherent frame of nationalism, which aided in the development of regional nationalism.

When Machado wrote his poem in 1913, his "two Spains" were that one was Catholic and reactionary and that the other was secular and progressive. Then between the founding of the Second Republic in 1931 and the start of the Civil War in 1936, several changes of alternating conservative and liberal governments occurred. During this time, the two views became discordant and Spain broke into two radical positions. Consequently when the military revolted and civil war began, the war was fought on ideological and cultural fronts. The Nationalists, or rebel side, portrayed the war as a Crusade against the reds of international communism. The Crusade with all its symbolism of Reconquista was supported by the Spanish Catholic Church, the Vatican, Fascist Italy, and Nazi Germany. The Republic portrayed the war as a conflict against a rebellious military that was supported by the forces of international fascism. The Republic was supported by the Soviet Union and by international volunteers. The war deepened the divide with both sides claiming to be the true preservers of Spanish history and culture. The war may also be viewed as a class war between landowners, the military, the clergy and workers, tradespeople, and intellectuals. The victory by Franco and the military only served to exacerbate the division. ${ }^{3}$

\footnotetext{
${ }^{2}$ Mariano José de Larra, "El Día de Difuntos de 1836: Fígaro en el cementerio.” El Español no. 368 (November 2, 1836).

${ }^{3}$ Dacia Viejo-Rose, Reconstructing Spain: Cultural Heritage and Memory after Civil War (Eastbourne, U.K.:

Sussex Academic Press, 2011), 30-35.
} 
Following the Civil War, Franco reinforced this division by vindictively bisecting the Spanish society into winners and losers, with the losing Republican side being largely without rights and excluded from any benefits from the state. People identified as Republicans were subjected to internal exile and worse. ${ }^{4}$ Up to 500,000 Republicans were imprisoned in concentration camps. ${ }^{5}$ According to Helen Graham, 20,000 Republican prisoners were forced into slave labor to build Franco's monument, Valle de los Caídos. ${ }^{6}$ During the transition to democracy following Franco's death, the divisions from the Civil War were papered over by a political agreement of de facto amnesty for the transgressions of the Civil War and the Franco regime, sealed by a 'pact of silence." The pact subsequently inhibited the recovery of Civil War memory for the next twenty-five years until the turn of the century. Spain continues to remain highly partisan and experiences identity crises. ${ }^{8}$

Although the idea of "two Spains" substantially reflects a politically divided Spain with two sides in opposition and continual conflict, it has been used to describe many social and political situations or developments. Following Franco's death, there was the idea of a "New Spain" applied to becoming a modern Spain, fully in line with mainstream Europe. There was also the idea of an "Old Spain" applied to political and social forces opposing change, especially to Francoists. The term has also been applied to many other tensions in Spain: nationalism versus regionalism, Catholic Spain versus secular, a Spain that functions and one that does not, modern versus reactionary, and in politics: progressive versus conservative.

Gunther et al argued that Spain is no longer much different from the main European countries. ${ }^{9}$ Indeed, many of the new generation born after Franco see themselves as European more than being part of one of the "two Spains." However, Spain does retain strong conservative and leftist elements and powerful regional forces threatening to break Spain apart. Today, Spain remains a multi-factional country with five culturally different regions, four languages, four major political parties, substantial illegal immigration, and sporadic political violence; all of which continue to create tension. The "two Spains" concept is especially well

\footnotetext{
${ }^{4}$ Helen Graham, “Coming to Terms with the Past: Spain’s Memory Wars,” History Today 54, no. 5 (May 2004$): 29$.

5 Sebastiaan Faber, "Revisiting the Past: Truth, Justice, and Reconciliation in Post-Franco Spain, a Review Article (Second Part)," Revista Hispánica Moderna 59, no. 1/2 (Jun. - Dec., 2006): 142.

${ }^{6}$ Graham, "Coming to Terms with the Past," 29.

${ }^{7}$ Ibid., 31.

${ }^{8}$ Felipe Sahagún, "Leaders of Divided Spain Square Off Yet Again,” Stratfor Global Intelligence, August 3, 2014.

${ }^{9}$ Gunther et al., Democracy in Modern Spain, 5.
} 
reflected by the two major political parties: the conservative Popular Party (PP) and the leftist Socialist Party (PSOE). The PSOE won the first national election in 1982 following the initial consensus government and continued to lead the government until 1996 when the PP won. The PP ran the government for the next eight years and a routine national election was scheduled for March 14, 2004, which the PP was expected to win. Then tragedy intervened on March 11.

\section{$\underline{11-\mathrm{M} \text { Attacks }}$}

The morning of March 11, 2004, saw commuters going on their daily trip to work or school on the Spanish rail system. Few people noticed the riders who left duffel bags or backpacks on several trains and got off of the trains, leaving their unknown contents behind. The world would find out the contents of these bags from news agencies later in the morning. At 7:37 AM, as a train was about to enter the Atocha station in Madrid, three bombs went off. ${ }^{10} \mathrm{~A}$ few seconds later, four additional bombs exploded on another train. These two attacks left nearly a hundred people dead, with numerous casualties. Emergency crews rushed to the station, but they had to deal with another two bombs destroying a train at the nearby El Pozo del Tío Raimundo station at 7:41 AM. 7:42 AM saw another bomb explode at the suburban Santa Eugenia station. ${ }^{11}$ In total, ten bombs went off and 191 people died and over 1,800 people were injured. ${ }^{12}$ Madrid and its suburbs were in chaos with first responders rushing to pull people from the twisted ruins of the destroyed trains. Most Spaniards were extremely shocked by the train bombings, which induced a highly emotional climate just prior to the national election. ${ }^{13}$ In fact, this series of attacks was the second deadliest terrorist attack in European history and the deadliest in Spain. ${ }^{14}$

Initially, the perpetrators were unknown. The attack was first blamed on the Basque separatist group Euzkadi Ta Azkatasuna (ETA), which had been behind previous attacks on Spanish police, politicians, and civilians. Mounting evidence proved otherwise, and the blame

\footnotetext{
${ }^{10}$ Lawrence Wright, “The Terror Web,” New Yorker, August 2, 2004. http://www.newyorker.com/magazine/2004/08/02/the-terror-web.

${ }^{11}$ Wright, "The Terror Web."

${ }^{12}$ Paul Hamilos, "The Worst Islamist Attack in European History," Guardian, October 31, 2007, accessed July 15, 2014, http://www.theguardian.com/world/2007/oct/31/spain/print.

13 José A. Olmeda, "Fear or Falsehood? Framing the 3/11 Terrorist Attacks in Madrid and Electoral Accountability," Real Instituto Elcano, Working Paper 24/2005, May 5, 2005, 17.

${ }^{14}$ The deadliest terrorist attack in European history was the 1988 Lockerbie plane bombing over Scotland, which had 270 deaths accounting for the passengers and those killed by falling debris.
} 
was shifted to Islamist terrorists at least inspired by Al Qaeda. ${ }^{15}$ The overwhelming verdict was that Islamist terrorists inspired by Al Qaeda perpetrated the attacks. Part of that conjecture was that Al Qaeda imitated the 9/11 attacks via four trains instead of four airplanes, 911 days after 9/11. ${ }^{16}$

\section{$\underline{\text { Research Questions }}$}

Spain has had a long and foundational history of political violence. Throughout most of the twentieth century, Spain was politically unstable. Following the civil war, the Franco regime repression and resistance group terror resulted in the perpetuation of fear. This fear persisted after Franco's death in 1975 and subsequent return of democratic rule as the past political violence and potential for its return, especially military revolt, continued to haunt Spaniards. Additionally the memory of the civil war was curbed throughout the Franco regime and for the next twenty-five years. This silent legacy of the memory of political violence, which had emerged into the public sphere at the turn of the twenty-first century, intensified following the train bombings of 11-M. This intensification of the breaking of the Civil War silence was aided by the election of the PSOE leader, José Luis Rodríguez Zapatero, whose grandfather was an officer in the Republican Army, was captured by Franco's Nationalist Army, and was executed as a prisoner. ${ }^{17}$

Considering that the 11-M attacks paled in significance compared to the Spanish Civil War, something happened following the attacks that intensified the breaking of the silence of the civil war legacy. Consequently, a variety of questions may be posed. What were the political and societal reactions to $11-\mathrm{M}$ and why did the resultant political controversies continue to the present time? How did the silencing of historical memory during the Franco years and afterward relate to the reactions to $11-\mathrm{M}$ and why did the recovery of memory intensify following 11-M? What caused the Spanish people's response to 11-M and its aftermath? In response to these questions, one of the main research areas of emphasis for this thesis is to examine the controversial aftermath of 11-M. Another research area of emphasis is the investigation of the

\footnotetext{
${ }^{15}$ Hamilos, "The Worst Islamic Attack in European History."

${ }^{16}$ Nicholas Manganas, "Mass-Mediated Social Terror in Spain," Comparative Literature and Culture 9, no. 1 (March 2007), Article 10: 2.

${ }^{17}$ Norman Birnbaum, "Spain's Recent History: Rebirth of a Nation," The Euromedia Blog, entry posted March 16, 2004, http://journalism.berkeley.edu/projects/euromedia/archives/002326.html (accessed July 10, 2014).
} 
recovery of memory from the Spanish Civil War. Although 11-M is not an isolated terrorist attack in Spain because of ETA terrorism, it seems atypical compared to the previous ETA political violence due to its scale and coordinated attacks. Due to the massive demonstrations following 11-M and the subsequent passing of the Law of Historical Memory in 2007, it seems reasonable to hypothesize that recovery of memory following the Franco regime was intensified by 11-M and the election of Zapatero. This law had the purpose of establishing a way to preserve both memories of the Spanish Civil War, which had re-emerged as a major political issue at the turn of the twenty-first century.

\section{Thesis Objectives}

Gaddis presented the metaphor of history as landscapes, which could be mapped to uncover the past. He contended that structure and process provide the mechanism of history and that structure may survive into the present. It is from these surviving structures that historians deduce the processes that produced them. Gaddis used the metaphor of a camera to see the underlying structure of history. ${ }^{18}$ This thesis focuses Gaddis' camera lens on the structure of Spanish duality to investigate the processes that produced the surprising response of the Spanish people to 11-M and the intensification of Civil War memory recovery.

Therefore, this thesis demonstrates that the Madrid terrorist attack and its aftermath significantly intensified the recovery of memory and the associated breaking of silence in Spain. Secondly, this thesis demonstrates that the Spanish people responded to 11-M with anger instead of fear, which is a controversial topic in historiography. To accomplish these purposes, the thesis is divided into two major sections. The first section discusses the political and social controversies following the attacks. Its purposes are to provide an overview of tensions caused by $11-\mathrm{M}$, analyze the surprising response of the Spanish people to the crisis, and relate those tensions to the duality of Spain. The second section reviews the history of memory and silencing following the Spanish Civil War including recent history. For instance, Faber has written about a particularly noteworthy and intense debate concerning Spanish Civil War historical memory that took place in Spain in 2010. The debate indicated a strong conflict between memory and

\footnotetext{
${ }^{18}$ John Lewis Gaddis, The Landscape of History: How Historians Map the Past (New York: Oxford University Press, 2002), 35; Ibid., 41; Ibid., 129.
} 
counter-memory. ${ }^{19}$ Hence, it can be argued that a historical memory war has been taking place in Spain regarding the Spanish Civil War and that Spain has remained divided about the Civil War. The purposes of the second section are to analyze why memory recovery intensified after 11-M, to examine the so-called memory war, and to relate memory recovery to the duality of Spain.

\section{Theory and Definitions Historiography}

A brief historiography on the definitions of memory, collective memory, silence, breaking of silence, recovery of memory, and amnesty as well as a discussion of trauma theory will help set the stage and provide focus for the discussion of memory and silence in this thesis. Pierre Nora analyzed the relationship between history and memory and argued that memory and history were "fundamentally in opposition." He defined memory as "life, borne by living societies founded in its name." 20 He also mentioned that memory is in constantly changing ideas and that it is easily manipulated and altered. He defined history as "the reconstruction, always problematic and incomplete, of what is no longer." 21 This distinction between history and memory is a major component in the argument over the national narrative of the Spanish Civil War. From a Spanish viewpoint, Salvador Cardús i Ros defined memory as "a set of narratives resulting from the social interpretation of reality."22 From a different perspective, Carolyn Boyd visualized memory as a process. She defined memory as "the process by which people construct personal narratives supportive of integrated and efficacious identities." 23 The differing definitions of memory boil down to this: memory is the result of recollections from individuals or groups of certain events or a series of events and how they are portrayed after they occur. History, it could be argued, is generally the record of events contextualized within the most accepted memory of those events as well as documentation or other evidence of the events. Spanish historians, especially those who focus on social history, discuss the memory of the Spanish Civil War as being multiple collective memories. This is because the memories of

\footnotetext{
${ }^{19}$ Sebastiaan Faber, "Raising the Specter of 'Argentinization': The Temptation of Spanish Exceptionalism," Hispanic Issues On Line, (Fall 2012): 119-123.

${ }^{20}$ Pierre Nora, “Between History and Memory: les lieux de mémoire," Representations 26 (1989): 8.

${ }^{21}$ Nora, "Between History and Memory," 3.

${ }^{22}$ Salvador Cardús i Ros, "Politics and the Invention of Memory, For a Sociology of the Transition to Democracy in Spain," in Disremembering the Dictatorship: The Politics of Memory in the Spanish Transition to Democracy, ed. Joan Ramon Resina (Atlanta: Editions Rodopi B.V., 2000), 23.

${ }^{23}$ Carolyn P. Boyd, "The Politics of History and Memory in Democratic Spain," Annals of the American Academy of Political and Social Science 617 (May, 2008): 134.
} 
wartime experience are diverse and divided, making unity toward a national narrative difficult if not impossible.

For example, Paloma Aguilar argued that the memory of the war is collective "which does not mean that all of the persons who make up the same group have an equal factual memory of a particular historical episode." 24 Therefore, collective memory differs depending on groups of people and depending on the status of a person in society. Elżbieta Hałas described social memory as the memory of a whole society, which is comprised of multiple collective memories. She defined collective memory as "the processes of communication and symbolic representations of the past experiences of a group." 25 She also indicated that collective memory has three important functions: "legitimization of the social order, formation of collective identities, and idealization of values." 26 Hałas referenced Paul Connerton in discussing how collective memory is created by generation to generation knowledge transmittal of group experience and how the vehicles of collective memory are generally in the form of commemorations. ${ }^{27}$ It is collective memory that differentiates social groups and group identity transformation occurs through commemoration changes about their origins. The intensity of commemoration has a direct bearing on collective memory. When commemoration fades, collective amnesia or oblivion begins. Hałas argued that there are two trends in collective memory: localization and globalization. Globalizing of collective memory was an outcome of the world wars, caused by "common frameworks of traumatic social experiences." These traumatic experiences produced deep divisions in collective memory, many of which became global after the Second World War and under the influence of the Cold War. Hence the politics of collective memory are no longer bound to the state, but are becoming global. When collective memory involves memory of trauma, it can have substantial power and collective memory conflicts generally open historical and political divisions. Indeed, the politics of memory can become revolutionary. Hałas specified that there are two ways to practice the politics of memory when conflict over the memory of trauma is involved and reconciliation is needed. One way is through amnesia or amnesty, which may particularly have utility during transitions. The other

\footnotetext{
${ }^{24}$ Paloma Aguilar, Memory and Amnesia: the Role of the Spanish Civil War in the Transition to Democracy, trans. Mark Oakley (New York: Berghahn Books, 2002), 1.

${ }^{25}$ Elżbieta Hałas, "Issues of Social Memory and their Challenges in the Global Age," Time \& Society 17, no. 1 (2008): 105.

${ }^{26}$ Hałas, "Issues of Social Memory," 110.

${ }^{27}$ Ibid., 107.
} 
way is through justice by investigating the past and coming to an acceptable legal remedy or forgiveness. Both ways have been practiced. ${ }^{28}$

Collective memory is related to national identity by how identity development occurs through listening to memories, standardized education, commemorations, popular art, historical literature and films, and media. Hence, problems of memory are problems of identity. National governments typically attempt to create an official public memory that forms a preferred version of the past. ${ }^{29}$ The Franco regime actively worked to shape public memory and the official representation of the Civil War became that of the Nationalist victors. As such, the Republican experience of loss, voices from their own past, and history, were over-shadowed by that of the Nationalists. This was especially true at commemorations, through narratives in education and in Catholic churches, and at statues and memorials to the Civil War. One major example is the Valley of the Fallen (which memorialized the Nationalist victors and became the tomb of Franco); in reference to which Aguilar quoted Nora by stating that it could be considered a "site of memory" or a social deposit where personal experiences shape tradition "prior to the existence of individuals of subsequent historical periods." 30 The storing of these individual memories is what shapes collective memory about events. Collective memories and individual memories influence each other and "collective memories are periodically revived by means of ceremonies or public rituals which aim to legitimise a present rooted in a specific tradition." ${ }^{31}$ The revival and perpetuation of collective memory also contributes to the forgetting or over-shadowing of other memories which can be viewed as "inconvenient" for the accepted memory. This type of over-shadowing occurs on a regular basis with historical events, and is known as silencing.

Silences about the past take place in all societies. It is impossible for every detail of every event that has occurred in human history to be documented. Sometimes events which should have, could have, or would have been recorded remain unrecognized and/or buried. In some cases, it is accidental as in the case of a letter being misplaced when it is taken to an archive or is destroyed by the passage of time. On the other hand, there are times when evidence

\footnotetext{
${ }^{28}$ Hałas, "Issues of Social Memory," 105-115.

${ }^{29}$ Viejo-Rose, Reconstructing Spain, 10-11.

${ }^{30}$ Pierre Nora, Les Liuex de Mémoire (Gallimard : Paris, 1984) in Memory and Amnesia, ed. Paloma Aguilar, 7.

${ }^{31}$ Aguilar, Memory and Amnesia, 7.
} 
is destroyed or events covered up in an attempt to make that aspect "forgotten" by future generations. Jay Winter defined silence as:

...a socially constructed space in which and about which subjects and words normally used in everyday life are not spoken. The circle around this space is described by groups of people who at one point in time deem it appropriate that there is a difference between the sayable and the unsayable, or the spoken and unspoken, and that such a distinction can and should be maintained and observed over time. Such people codify and enforce norms which reinforce the injunction against breaking into the inner space of the circle of silence. $^{32}$

Michel-Rolph Trouillot said that "silences enter the process of historical production at four crucial moments: the moment of fact creation (the making of sources); the moment of fact assembly (the making of archives); the moment of fact retrieval (the making of narratives); and the moment of retrospective significance (the making of history) in the final instance."33 In Spain, silences play a major role in the remembrance of the Spanish Civil War and are a result of all four crucial moments of the production of silence. The success of the Franco regime over other regimes, such as those of Mussolini and Hitler, was because the regime was in charge of all these crucial moments until the 1970s. It can be said that the strength of the regime allowed it to promote its account of the Civil War to a status of privilege.

A key duality struggle faced by Spaniards following the transition from the dictatorship to democracy was dealing with the compounded silences about the atrocities of the Spanish Civil War and the Franco dictatorship and the need to break those silences if society was to be healed. The breaking of silence is when topics/traumas which were too taboo to be openly talked about, at one point or another, become acceptable within the established framework of society and politics. Ricoeur equated forgetting to silence, which he considered to be blocked memory, with the breaking of silence being the unblocking of the silenced memory. ${ }^{34}$ This happens, as explained by Winter, because the silence could have been put in place "in order to suspend or

\footnotetext{
32 Jay Winter, "Thinking about Silence," in Shadows of War: A Social History of Silence in the Twentieth Century, ed. Efrat Ben Ze'ev, Ruth Ginio, and Jay Winter (New York: Cambridge University Press, 2010), 4.

${ }^{33}$ Michel-Rolph Trouillot, Silencing the Past: Power and the Production of History (Boston: Beacon University Press, 1995), 26.

${ }^{34}$ Paul Ricoeur, Memory, History, Forgetting, trans. Kathleen Blamey and Daniel Pellauer (Chicago: The University of Chicago Press, 2004), 448.
} 
truncate open conflict over the meaning and/or justification of violence, either domestic or transnational." 35 Vincent discussed how the passage of time is necessary for difficult subjects to be discussed politically or publically before the silence may be broken. Often it is several generations after the event before it can be examined closely and it can emerge outside the realm of academia, which was the case with the Spanish Civil War and the Franco era. Vincent related that the breaking of silence is about confronting and revealing the past, which has been hidden or kept from public knowledge. ${ }^{36}$ The purpose of the breaking of silence is the recovery, or rehabilitation, of hidden memory.

Ricoeur described remembering (recovery of memory) as a moment of awakening and as a moment of recognition. ${ }^{37}$ In other words, recovery of memory happens when the forgotten or the silenced is recognized. Ricoeur also maintained that the process of memory recovery is related to the process of mourning. He asserted that collective memory must detach from personal or retention memory for the past to separate from the present. ${ }^{38}$ Vincent saw the process of memory recovery in Spain as "a renegotiation of the public narratives of the dictatorship and the Civil War" or that it "is not a recovery of a lost past but a reordering of historical narratives accomplished in a changing present." 39 Labanyi viewed memory recovery in Spain as the recuperation of memory. She related memory recovery to uncovering the "unfinished business" of the past. ${ }^{40}$ Hałas characterized memory recovery as the regaining of collective memory from that which had been previously hidden. She noted that "there can be a discrepancy between the memory of the past of a particular group and the historiography of its experiences." 41 Blakeley portrayed memory recovery in Spain as the re-emergence of that which was long dead and buried. She said that these memories were not forgotten, but had been sidelined until the political opportunity structure (Tarrow) was ready for its re-emergence. ${ }^{42}$

\footnotetext{
${ }^{35}$ Winter, "Thinking about silence," 4-5.

${ }^{36}$ Mary Vincent, "Breaking the silence? Memory and oblivion since the Spanish Civil War," Shadows of War: A Social History of Silence in the Twentieth Century, ed. Efrat Ben Ze'ev, Ruth Ginio, and Jay Winter (New York: Cambridge University Press, 2010), 64-65.

${ }^{37}$ Ricoeur, Memory, History, Forgetting, 40-41.

${ }^{38}$ Ibid., 337.

${ }^{39}$ Vincent, "Memory and oblivion since the Spanish Civil War," 65.

40 Jo Labanyi, "Memory and Modernity in Democratic Spain: The Difficulty of Coming to Terms with the Spanish Civil War," Poetics Today 28, no. 1 (Spring 2007): 106; Ibid., 113.

${ }^{41}$ Hałas, "Issues of Social Memory," 111-112.

42 Georgina Blakeley, "Digging Up Spain's Past: Consequences of Truth and Reconciliation," Democratization 12 , no. 1 (February 2005): 52.
} 
A dictionary definition of amnesty is "a general pardon granted by a government, especially for political offenses. ${ }^{43}$ It originates via Latin from the Greek amnēstia meaning not remembered or oblivion. A dictionary definition of amnesia is "partial or total loss of memory, usually resulting from shock, psychological disturbance, brain injury, or illness" and it originates from the Greek amnēsia meaning without memory or forgetfulness. ${ }^{44}$ Although the Greek roots of amnesty and amnesia are essentially the same, the English definitions are not. Paul Ricoeur argued that the boundary between amnesty (forgiving) and amnesia (forgetting) has been blurred by institutionalized forms of amnesty, which he called commanded forgetting. ${ }^{45} \mathrm{He}$ further stated:

The significance of amnesty is quite different. To begin with, it brings to conclusion serious political disorders affecting civil peace - civil wars, revolutionary periods, violent changes of political regimes - violence that the amnesty is supposed to interrupt... With regard to its content, amnesty is directed toward a category of infractions and crimes committed on all sides during the period of sedition. In this respect, it functions as a sort of selective and punctual prescription which leaves outside of its field certain categories of lawbreakers. ${ }^{46}$

Contrary to the stated aim of reconciliation and peace, institutional forgetting when clothed as amnesty, has attempted to bury the memory of the past, and as such, has entailed a secret pact to deny memory and was no longer forgiving. ${ }^{47}$ Commanded forgetting is in effect commanded amnesia and as such, private and collective memory would lose the healthy identity crisis that could allow reclamation of the past and discharge of its trauma. Ricoeur finished his discussion by stating: "the boundary between amnesty and amnesia can be preserved in its integrity through the work of memory, which work is completed by the work of mourning and guided by the spirit of forgiveness. ${ }^{\prime 4}$

\footnotetext{
${ }^{43}$ The American Heritage Dictionary of the English Language: Third Edition (Boston: Houghton Mifflin Company, 1992), 61.

${ }^{44}$ The American Heritage Dictionary, 61.

${ }^{45}$ Ricoeur, Memory, History, Forgetting, 452-453.

${ }^{46}$ Ibid., 453.

${ }^{47}$ Ibid.

${ }^{48}$ Ibid., 456.
} 
As previously mentioned, amnesty is not forgetting. Winter discussed that amnesty attempts to transcend revenge paralysis and should be utilized when there is a consensus that amnesty results in more justice than continuation of conflict. If consensus fractures over time, then the amnesty may be renegotiated. Although opening the terms of amnesty seems counter to the concept of forgiveness lasting forever, Winter referenced that this happened in Argentina in 2005 when amnesty laws were declared unconstitutional. Regarding Civil War silencing in Spain, he mentioned that the uncovering of mass Republican graves has begun to sever the amnesty. ${ }^{49}$

Trauma is a serious physical or mental wound or shock to a person, either from violence or an accident. Sometimes, the mental or emotional stress from the trauma produces a substantial, long-lasting, disordered psychic or behavioral state in a person. ${ }^{50}$ Some survivors of combat relive the horror of experienced traumatic events in flashbacks and nightmares. This condition was in the past termed "shell shock," but was changed to the term post-traumatic stress disorder (PTSD) following the Vietnam War. The advent of total war in the First and Second World War extended the horror of war to civilians and many suffered PTSD after experiencing unimaginable brutality from attacks on cities and towns. Survivors of the Nazi genocide and prisoners of war likewise experienced horrendous atrocities and many suffered from PTSD. Classic models of stress theory, stress sensitization, and fear conditional have been adequate to explain the biological process of PTSD, but have not been able to explain individual differences in reaction to trauma. ${ }^{51}$ A physical or psychological threat induces an expedient and efficient natural response in everyone, since this is a survival mechanism. Normally, the duration of this response to stress is limited since prolonged stress may potentially be damaging. However, in the case of PTSD, the physiological response to a stressor event does not seem to turn off. ${ }^{52}$ Why this happens to some people and not others has galvanized research into whether or not genetic differences may account for different reactions to trauma and associated PTSD.

\footnotetext{
${ }^{49}$ Winter, "Thinking about Silence," 18.

50 The American Heritage Dictionary, 1904.

${ }^{51}$ Rachael Yehuda and Linda M. Bierer, "The Relevance of Epigenetics to PTSD: Implications for the DSM-V," $J$. Trauma Stress 22, no. 5 (October 2009): 428.

52 Jason J. Radley et al., "Stress Risk Factors and Stress-Related Pathology: Neuroplasticity, Epigenetics and Endophenotypes.” Stress 14, no. 5 (September 2011): 2.
} 
Recent research in the new science of epigenetics has found that trauma can induce changes in a person's DNA, which are inheritable. Studies of children of Holocaust survivors have shown that they are more likely to have psychological distress and that some have inherited genetic changes caused by the trauma suffered by their parents. The epigenetic modifications are believed to be a direct result of DNA methylation. ${ }^{53}$ These gene alterations may be why trauma victims have such long-lasting PTSD. ${ }^{54}$ Therefore, it is likely that intergenerational effects of trauma have at least two causes: inherited gene modifications and upbringing or learning factors from growing up with traumatized parents.

Individual exposure to direct traumatic incidents is related to psychological distress including PTSD, but does exposure to mass traumatic incidents cause similar stress and a risk of psychological problems? Studies have indeed found higher levels of PTSD among people who were exposed to the trauma as a direct witness, having a friend or relative killed, or to a lesser extent having been involved in the rescue. ${ }^{55}$ In the case of long-term stress exposure, e.g. extended combat or political repression, people have to employ long-term adaptations to handle the adversity. Many of the adaptations may be permanent, e.g. neural and genetic changes, which may make normal stress response systems hyper-reactive, increasing the risk for PTSD. ${ }^{56}$ Long-term stress is therefore especially damaging.

Trauma theory contends that for a situation to be traumatic to a person, it must be more than simply a situation that renders helplessness: it must also include a betrayal of trust. ${ }^{57}$ Together, this entails two shattered assumptions about themselves and the environment or world: personal invulnerability and perception that the world is safe. These assumptions are overturned by the traumatic situation and psychological distress arises from new feelings in which the person sees themselves as vulnerable to victimization and that the world is treacherous and dangerous. ${ }^{58}$ Partaking in violence or witnessing violence can provoke a feeling of shame, which

\footnotetext{
${ }^{53}$ Rachel Yehuda et al., "Holocaust Exposure Induced Intergenerational Effects on FKBP5 Methylation,” J. Biological Psychiatry In Press, Published Online (August 12, 2015): 1-9.

${ }^{54}$ Yehuda and Bierer, "The Relevance of Epigenetics to PTSD," 427.

55 Juan J. Miguel-Tobal et al., "PTSD and Depression After the Madrid March 11 Train Bombings," Journal of Traumatic Stress 19, no. 1 (February 2006): 70; Ibid., 74.

${ }^{56}$ Radley et al, "Stress Risk Factors," 2.

57 Jenny Edkins, Trauma and the Memory of Politics (New York: Cambridge University Press, 2003 ), 4.

${ }^{58}$ Daphna Canetti-Nisim, Eran Halperian, Keren Sharyit, and Stevan E. Hobfoll, "A New Stress-Based Model of Political Extremism: Personal Exposure to Terrorism, Psychological Distress, and Exclusionist Political Attitudes," J. Conflict Resolution 53, no. 2 (June 2009): 367.
} 
can be as traumatic as being a victim and hence potentially leading to PTSD. Holocaust survivors, who escaped brutality, but witnessed it, said that they drowned in shame. Combat veterans who have killed or terrorized civilians have also expressed having strong feelings of shame. ${ }^{59}$

Violence is typically foundational for nations and survival of the nation requires that its citizens will voluntarily fight or will accept conscription. In return, the nation offers security to its citizens. However, many nations or even quasi-states, particularly with autocratic rulers, abuse their power over their citizens and break the security trust. This political abuse can range from exclusion from opportunity and benefits; to imprisonment, torture, and death' to enforced participation in atrocities. Depending on the degree of stress, political abuse can cause psychological distress and PTSD. Political abuse victims, as evident by the Holocaust survivors, have a compelling need to tell their story and to attempt to right the wrong done to them. Due to the powerless state of survivors at the time of the trauma, being able to speak and pursue justice afterwards is their way of resistance and speaking helps alleviate psychological distress. On the other hand, political authorities may feel threatened by survivor testimony and may take action to silence them. Recovery of power is important to the recovery of trauma victims. However, survivors of great trauma never fully recover trust and live in fear of the return of trauma. ${ }^{60}$

Memorials are made following wars. If victory was achieved, commemorations, films, books, and museums speak of the honor and sacrifice of the military and war effort. Even the losers build museums. The commemorations serve to strengthen the nation and to ease mourning for the fallen. ${ }^{61}$ But how are victims, especially of genocide, commemorated? Generally, silence is broken and the victims' stories are told through museums, films, books, art, and at trauma sites. Justice may be pursued through truth and reconciliation commissions and courts, but sometimes these become spectacles and the victims' stories may become sensationalized creating more trauma for the victims. Television is often a hindrance to hearing

\footnotetext{
${ }^{59}$ Edkins, Trauma and the Memory of Politics, 4-5.

${ }^{60}$ Ibid., 5-8.

${ }^{61}$ Ibid., 1.
} 
the true voices. ${ }^{62}$ Another hindrance is if a memory is politicized. The controversies which are explored in the next section show the effect politics had on the memory of 11-M.

\footnotetext{
${ }^{62}$ Edkins, Trauma and the Memory of Politics, 18.
} 


\section{CONTROVERSIAL AFTERMATH OF 11-M}

Ten years later, there are few visible signs of what happened on that day. Even the shadow of things, commemoration, has a discreet presence. There is the 11-metre-high crystal monolith erected in tribute to the victims outside Atocha station where one of the trains exploded; but the memorial across the street is perhaps more moving. Known as the Forest of Remembrance, it is a little park with olive trees and cypresses, one for each of the victims. It is calm and collected; a place to be, rather than a monument to observe.

I wish the legacy of 11 March was as simple as that park. Grief is easy to share, but when it comes to meaning Spain's memory of the Madrid train bombings appears fatally tainted by domestic politics; and when one thinks of the magnitude of the tragedy it is almost embarrassing to explain why.

What is unfortunate is that the controversy continues to affect the way in which the tragedy is remembered in Spain. Official commemorations avoid speeches. If there are speeches, specifics are left out. What was an act of mass murder tends to be treated in terms of abstract evil. But there might be a silver lining here too. In a way, this lack of interpretation has made it more universal - like Guernica, hanging on a wall a few hundred metres up the street.

Miguel-Anxo Murado: Madrid Bombings, 10 Years On, $2014^{63}$

As Murado so succinctly states in his Guardian article, the aftermath of 11-M produced political and social controversies that remain to the present time. How did this happen? Why did this happen? This chapter seeks to answer those questions.

$\underline{\text { Immediate Aftermath Timeline }}$

The four day period immediately following the 11-M attack was highly consequential. Typically following terrorist attacks, everyone including the opposition political parties rally in solidarity behind the government and its response to such an attack with only a few dissenting voices, as was seen in the response to $9 / 11$. That solidarity initially happened in Spain, but

\footnotetext{
${ }^{63}$ Miguel-Anxo Murado, "Madrid Bombings, 10 Years On: The Lack of a Backlash has the power of a new Guernica," Guardian, 11 March 2014, Accessed September 4, 2015, http://www.theguardian.com/commentisfree/2014/mar/11/madrid-bombings-guernica-conspiracy-islamists-eta.
} 
began to break down within twenty-four hours of the attack. A summary of events can provide insight into the immediate aftermath of 11-M.

\section{Thursday, March 11, 2004}

Shortly after the train bombings, the key political leaders in Spain attributed the attacks to ETA including the PSOE opposition leader Zapatero, President of the Government Aznar, PP leader Rajoy, and the Basque regional government President. Aznar set up a Crisis Cabinet which excluded Congress, Defense, State Security, Intelligence, and opposition political parties. Aznar called for solidarity demonstrations the afternoon of March 12. The Minister of the Interior, Ángel Acebes, became the government spokesperson. In a press conference, Acebes began to build a case that the perpetrators were the ETA. The Minister of Foreign Affairs began the process to obtain a UN Security Council resolution condemning ETA for the attacks. However, ETA spokesman, Arnaldo Otegui, released a statement denying ETA involvement. ${ }^{64}$ Aznar held a press conference. In his opening statement, he said: "We will defeat them. Let nobody have any doubt. We will succeed in putting an end to the terrorist band, with the strength of the rule of law and the unity of all Spaniards."65 His reference to a "terrorist band" implied ETA. During the evening, Aznar called the editors of Spain's newspapers and confidently told them that ETA was "behind the attacks.",66

The police investigation had a quick break when police in Alcalá de Henares were tipped off by a witness who directed the authorities to a white Renault van that had been left that morning at the train station. ${ }^{67}$ Though the authorities were initially suspicious of ETA having committed the attack, they were baffled by the lack of warning (in direct opposition to previous attacks) and the poor preparation (plates on the van did not match registration of similar vehicles) which was out-of-character for the Basque terrorist group. However the investigation was sidetracked when an explosive informant at the scene stated that the bombs used titadyne explosive, which implicated the ETA. ${ }^{68}$ The white Renault van found at Alcalá de Henares rail

\footnotetext{
${ }^{64}$ Olmeda, "Framing the 3/11 Terrorist Attacks in Madrid and Electoral Accountability," 18-21.

65 José María Aznar, "Declaración Íntegra de José María Aznar sobre los Atentados de ETA en Madrid,” March 11, 2004.; Translation by me. Original text: "Les derrotaremos. Que no tenga nadie ninguna duda. Lograremos acabar con la banda terrorista con la fuerza del Estado de Derecho y con la unidad de todos los españoles."

${ }^{66}$ Birnbaum, "Rebirth of a Nation."

${ }^{67}$ Wright, "The Terror Web."

${ }^{68}$ Olmeda, "Framing the 3/11 Terrorist Attacks in Madrid and Electoral Accountability," 19.
} 
station was searched by authorities and within it they found a tape of Quranic recitations in Arabic, traces of an outdated explosive type (Goma-2), and seven fuses made in Spain. ${ }^{69}$ Goma2 had formerly been used by ETA, but many years before this attack. Police officials determined that the designation of titadyne as the bombing explosive was not correct and they opened a new investigation direction, but without halting the ETA investigation. ${ }^{70}$

During the evening, the media started questioning the government claim of ETA perpetuation. Radio station Cadena Ser broadcast a rumor that a suicide bomber had been found among the bodies. Although the rumor was denied, the suicide bomber story coincided with a story from London that Al Qaeda had released a statement claiming responsibility for the attack. Norwegian intelligence following up on the Madrid attack obtained a document posted on a jihadist web page the previous December which discussed the possibility of an attack on Spain. This document had been drafted as early as September and it mentioned other minor attacks which had occurred on Spaniards in Iraq. The document provided to the Spanish authorities made mention of an historic Islamic figure by the name of Abu Dujana, a companion of the Prophet. This name had been evoked by other jihadists and suicide bombers in other attacks. ${ }^{71}$ Though the authors of the document were not known, reference was made to the assumed name of the man who on March 13 would identify himself as a member of the group responsible for the attack.

The events of the day of the bombings indicated that the first political response to the crisis was solidarity with the government in blaming ETA. The ETA was quick to deny they were behind the bombings. Information flowing from outside of Spain began to indicate that maybe Islamists were involved. The media began to react to that other information in the evening and began to sow the first seeds of doubt.

\section{Friday, March 12, 2004}

Overnight, as the police were sorting through belongings found on the trains, a police officer discovered a sports bag with Goma-2 explosives surrounded by nails and screws inside. Along with the explosives, a cellular phone was found. The officers took a chip from the phone

\footnotetext{
${ }^{69}$ Hamilos, "The Worst Islamist Attack in European History."

${ }^{70}$ Olmeda, "Framing the 3/11 Terrorist Attacks in Madrid and Electoral Accountability," 21.

${ }^{71}$ Wright, "The Terror Web."
} 
which showed the most recent dialed numbers. Tracing the calls, they were able to map out a network of Arab and African immigrants, many of whom were already known to Spanish intelligence.

In the morning, Zapatero started to criticize the government for not responding to the potential that Al Qaeda was behind the attack. He also asked the government to be more open in the sharing of information. Aznar held a press conference at which he said that all lines of investigation were being pursued, but he attacked the ETA spokesman by saying: "The government gives no credit to spokespersons of ETA and its illegal satellite organizations." A journalist asked about a statement from the PSOE Secretary of Organization accusing Aznar and the government of hiding information. Aznar denied the accusation and mentioned that information would be provided about the Arabic tape as soon as it was analyzed. He again reiterated the ETA blame narrative with an emphasis on the thirty-year history of ETA terrorism and the similar modus operandi of this attack. ${ }^{72}$

In the afternoon, word began to leak about the new turn in the investigation. Demonstrators soon formed in front of the Atocha station to protest the war in Iraq, which some linked to the bombing. As the war had been unpopular in Spain from the beginning and had been pushed through by Aznar without reaching a consensus with the other parties, many Spaniards blamed Aznar and the PP party for putting Spain in a position to be attacked. ${ }^{73}$

Over 11,000,000 people, which was over twenty-five percent of the total Spanish population, turned out for the government called unity demonstrations. But unity was breaking down. In some cities, people demonstrated against ETA, but in Barcelona, PP politicians were attacked, and in Madrid people asked for the truth. ${ }^{74}$ Some of the media began questioning whether ETA was behind the attack. El País, the largest daily newspaper in Spain, editorialized that if Al Qaeda was responsible for the attack, it would be an extension of the Iraq War onto Spanish soil. The editorial blamed the government for using the ETA attack narrative as a means to improve the PP position in the election. ${ }^{75}$ The conservative daily newspaper, El Mundo, was

\footnotetext{
${ }^{72}$ Olmeda, "Framing the 3/11 Terrorist Attacks in Madrid and Electoral Accountability," 23-24.

${ }^{73}$ Ibid., 4-6.

${ }^{74}$ Ibid., 23.

75 Editorial, “11-M,” El País, March 12, 2004.
} 
also critical of the government for so quickly settling on ETA responsibility and especially criticized the Minister of the Interior for allowing his prejudices to overrule the data. ${ }^{76}$

In an evening press conference, the Interior Minister, Ángel Acebes, continued to insist in public that ETA was still the prime suspect of the attack; even though the police investigation showed that ETA could not have been directly involved. Acebes went as far to state that "so far, none of the intelligence services or security forces we have contacted have provided reliable information to the effect that it could have been an Islamic terrorist organization."77 However, anonymous callers claiming to represent ETA called into Basque newspapers and television stations during the day to deny responsibility for the attacks. Spaniards came out in force that night to protest the violence and the Iraq war, with many asking "Who is the author of these attacks... Why is the government lying to us?"78

In this second day of the crisis, the PSOE opposition leader started to question the government narrative. The ETA more intensively denied they were the bombers. The police investigation was efficiently proceeding and started a second line of investigation into possible Islamist terrorists. The media initiated editorials and stories that began to counter government claims. The public massively responded to the government request for demonstrations, but some of the demonstrations turned into protests. The government was losing control of its narrative.

\section{Saturday, March 13, 2004}

In the morning, following the clue of the cellular phone card recovered from the bomb containing sports bag, the police investigation led to a store managed by two Indians and from there to a booth handled by three Moroccans, who were arrested. ${ }^{79}$ One of the Moroccans was Jamal Zougam, who had been under surveillance for suspected ties to Al Qaeda. ${ }^{80}$

Although the day before an election in Spain is a day of reflection with prohibition of electioneering, demonstrators in the afternoon surrounded many PP offices accusing the

\footnotetext{
${ }^{76}$ Editorial, "Nuestro 11-S," El Mundo, March 12, 2004.

${ }^{77}$ Elaine Sciolino, Lizette Alvarez, and Dale Fuchs, "Bombings in Madrid: Reaction, Grieving Crowds in Spain Seethe at Train Attacks," New York Times, March 13, 2004, accessed February 24, 2015, http://www.nytimes.com/2004/03/13/world/bombings-in-madrid-reaction-grieving-crowds-in-spain-seethe-at-trainattacks.html.

${ }^{78}$ Wright, "The Terror Web."

${ }^{79}$ Olmeda, "Framing the 3/11 Terrorist Attacks in Madrid and Electoral Accountability," 25.

${ }^{80}$ Wright, "The Terror Web."
} 
government of lying. ${ }^{81}$ The El País newspaper editorialized that the government blaming of ETA was only a hypothesis and not based on actual clues, which the newspaper listed. The Minister of the Interior was criticized for his continuing stance on ETA blame. ${ }^{82}$ The El Mundo newspaper editorialized that both investigation lines should remain open and recommended that people vote for Rajoy. ${ }^{83}$

Acebes, in a press conference, admitted that two lines of investigation were open, but he continued to insist that ETA was the responsible group. During the evening, Acebes released a statement announcing the arrests of terrorist suspects, but did not close the ETA investigation. Radio station Cadena Ser broadcast that large numbers of people were demonstrating against the government in most major Spanish cities. Rajoy, the PP candidate for President of the Government released a statement condemning the demonstrators surrounding PP offices. He also asked the people to vote for the PP party because they provide the best "defense against terrorism." The PSOE party released a statement saying that: "Spanish citizens deserve a government that does not lie to them, that always tells the truth... We will never, never, use terrorism as a political weapon... We have not convoked the demonstrations. ${ }^{.84}$

The police investigation began to solidify on Islamists after a man in the evening called a television station to notify them of a videotape placed in a trash bin near Madrid's main mosque; a video in which a masked speaker stated:

We declare our responsibility for what has occurred in Madrid, exactly two-and-a-half years after the attacks on New York and Washington. It is a response to your collaboration with the criminals Bush and his allies. This is a response to the crimes that you have caused in the world, and specifically in Iraq and Afghanistan, and there will be more, if God wills it. You love life and we love death, which gives an example of what the Prophet Muhammad said. If you don't stop your injustices, more and more blood will

\footnotetext{
${ }^{81}$ Olmeda, "Framing the 3/11 Terrorist Attacks in Madrid and Electoral Accountability," 25.

${ }^{82}$ Editorial, "Después de la matanza," El País, March 13, 2004.

${ }^{83}$ Editorial, "Un presidente para hoy, un relevo para mañana." El Mundo, March 13, 2004.

${ }^{84}$ Olmeda, "Framing the 3/11 Terrorist Attacks in Madrid and Electoral Accountability," 26-27.
} 
flow and these attacks will seem very small compared to what can occur in what you call terrorism. $^{85}$

This masked speaker identified himself as the "military spokesman for Al Qaeda in Europe," and named himself as Abu Dujan al-Afghani. ${ }^{86}$ At this point, Spaniards knew that it was not likely that ETA was behind the attacks due to the released information on the attack and its details and the PSOE were openly accusing their opponents of lying about the investigation. ${ }^{87}$ The following day would show that a portion of the Spanish electorate felt they were betrayed by their leaders.

In the third day of the crisis, the government narrative unraveled. The police made their first arrests of possible Moroccan terrorists. The media became more critical of the government. The PSOE opposition accused the government of lying. However, the government remained entrenched in their narrative of blaming ETA. Protests against the government continued throughout the country.

\section{Sunday, March 14, 2004 - Election Day}

At daybreak, demonstrators continued their protest against the PP government. The electorate was motivated, especially young and first-time voters. A larger-than-expected turnout of voters, seventy-six percent of the electorate, pushed the PSOE ahead of the Popular Party to oust the PP government and herald in the government of Zapatero. ${ }^{88}$ Most of the increased turnout voted for the PSOE. The PP had nearly the same number of votes as in the 2000 election. Zapatero then fulfilled his election promise to bring Spanish troops home from Iraq.

Two weeks after the election on April 2nd, a security guard found a plastic bag filled with Goma-2 next to the tracks for the AVE high-speed train. These explosives had been wired incorrectly and if they had gone off, casualties would have been at least double the amounts for the Madrid attack. ${ }^{89}$ The presence of the explosives two weeks after the initial attack, especially in the aftermath of an apparent political victory for the terrorists in ending Spanish-involvement

\footnotetext{
85،'Full Text: ‘Al-Qaeda' Madrid Claim,” BBC News, last modified March 14, 2004, http://news.bbc.co.uk/2/hi/europe/3509556.stm.; Wright, "The Terror Web."

${ }^{86}$ Wright, "The Terror Web."

${ }^{87}$ Ibid.

${ }^{88}$ Olmeda, "Framing the 3/11 Terrorist Attacks in Madrid and Electoral Accountability," 27-28.

${ }^{89}$ Hamilos, "The Worst Islamist Attack in European History."
} 
in Iraq, showed that the terrorist group was not interested in merely attaining a short-term political goal, which had already been achieved: they also wanted to exact revenge and have more blood spilled. The remote detonation present at the tracks also showed that the terrorists were interested in carrying out other attacks and not simply committing suicide. Fernando Reinares argued in an opinion piece published in April 2014 that the train bombings and the discovered bomb by the AVE tracks showed that the full plan of attack by the terrorists was not complete. ${ }^{90}$ Hence, the motivation for the 11-M attacks was to conduct political violence against Spain for a broader terrorism purpose. The day after this failed explosive was discovered authorities found and confronted the suspected terrorists in the Madrid immigrant suburb of Leganés.

At 3:00 PM on April $3^{\text {rd }}$, police went up to an apartment building in Leganés and saw a young Moroccan man taking the trash out. This man suddenly yelled something in Arabic and ran away from the police, so quickly that he could not be caught. Voices then yelled out from an upper floor "Allahu Akhbar!" and gunfire rained down on the police below. ${ }^{91}$ The police quickly closed down the area, evacuated the surrounding buildings, and heavy police firepower (including tanks and helicopters) moved into the neighborhood to start the siege of the apartment building. Throughout the six-hour siege the police tried to negotiate with the terrorists, the terrorists tried to get their suicide to be "morally sanctioned" by an Islamic cleric imprisoned in Britain, and Abu Dujan al-Afghani tried to salvage his operation by making further demands of the Spanish government. ${ }^{92}$ In the end, at 9:05 PM, the police stormed the apartment and ordered the men to come out. ${ }^{93}$ When they did not come out, the police destroyed the lock on the door and fired tear gas into the room. Almost simultaneously, an explosion rocked the apartment and ended the siege.

The explosion came from inside of the room, later discovered by the police to have been from Goma-2 explosives and detonators which were similar to those used in the train bombings, and resulted in the immediate deaths of the terrorists and one police officer. Alongside the

\footnotetext{
${ }^{90}$ Fernando Reinares, “Los planes pendientes tras el 11-M,” El País, April 7, 2014.

${ }^{91}$ Wright, "The Terror Web."

${ }^{92}$ Wright, "The Terror Web."; Ibid. The cleric the terrorists tried to contact in prison was Abu Qatada, a major radical influence on many of the terrorists who struck Western targets (including the leader of the 9/11 attack, Mohamed Atta); Ibid. Al-Afghani's fax, which was sent to the newspaper $A B C$, demanded that troops leave Iraq and Afghanistan. Otherwise, he stated, "we will turn Spain into an inferno and make your blood flow like rivers."

${ }^{93}$ Wright, "The Terror Web."
} 
explosives, the police were also able to locate a videotape in the wreckage. Piecing the remains of the tape together, they were able to view the final statement of three of the members of the cell. This cell identified itself as "the brigade situated in Al Andalus" and that they would "continue our jihad until martyrdom in the land of Tariq ibn Ziyad."94 This reference to Muslim Spain after the conquest of the Moors in the eighth century and prior to La Reconquista in the fifteenth century paralleled the references to the Muslim past in Spain that Al Qaeda made in messages directed at the West, in which the radicals deemed it necessary to recover the formerly Muslim lands of "Al-Andalus" from Spain. ${ }^{95}$ The political and social unrest created by the attacks was only beginning.

\section{1-M Historiography}

Historiography on 11-M and its aftermath is relatively scarce with only a few published books and a handful of dissertations and theses. Immediately following the attacks, there was a large volume of journalistic articles followed by academic articles. An academic study by José A. Olmeda into why the PP government immediately placed the blame for the attack on ETA found that the PP was running a narrative during the election campaigning that highlighted their record on 'the fight against terrorism' with candidates making accusations that the nationalist PNV party, which governed the Basque country, was using the threat of ETA attacks to further their power. The narrative also attacked the PSOE for being lenient on terrorism and for being aligned with Catalonian separatism. Furthermore, Olmeda reported that following an ETA announcement on February 18, 2004, of a ceasefire in Catalonia, the Spanish Ministry of Interior responded by declaring a 'maximum terrorism alert' with a prediction that there would be a terrorist attack ostensibly by ETA before the March 14 election. The recent history of ETA also greatly influenced the government in their initial reactions. One example was that on December 24, 2003, ETA planted two bombs made of twenty-four kilograms of titadyne (commercial brand of dynamite) in backpacks on an intercity train to Madrid to explode twenty minutes after arrival at the Chamartin Station. The titadyne had been stolen in France. A second example was that on February 28, 2004, a van containing five hundred six kilograms of homemade explosive and thirty kilograms of titadyne was stopped in Cañaveras. The van was intended to produce a

\footnotetext{
${ }^{94}$ Wright, "The Terror Web."

95 Hamilos, "The Worst Islamist Attack in European History."
} 
massive explosion near Alcaláde Henares, which is where the bombs were planted on three of the four trains on 11-M. The similarities of these two ETA incidents to 11-M likely factored in the government's reaction to $11-\mathrm{M} .^{96}$

Olmeda also examined the elections and how the results of the elections were influenced by the attacks, as well as how the parties were able to use the attacks to their electoral advantage. $\mathrm{He}$ argued that the bombings had a massive impact on the elections due to the framing of the attack, the mobilization against terrorism, and flash mobs which descended on PP election offices in the days following the attacks. ${ }^{97} \mathrm{He}$ concluded that the opposition parties were successful in framing the government's political support for the Iraq war as belligerence before the attack and the failure of the government to counter-frame this argument, which resulted in the PP taking the blame for the security crisis in the days following the bombings. ${ }^{98}$

Luis Moreno studied the impact of 11-M on the 2004 election and on regional politics. He mentioned that the usual outcome of elections in the time of crisis is to support the incumbent government, but the opposite occurred following 11-M. He argued that the PP government faced a political dilemma with two options. The first was if the PP disclosed that an Islamist organization had attacked Spain, then Aznar's vastly unpopular decision to send soldiers to Iraq would become a damaging issue for the PP in the election. The second option was to assert that ETA was to blame, which would reinforce the popular and successful PP hardline stance on ETA and would be advantageous for PP in the election. The second option was selected and was propagated to the media by Aznar and his spokesman Acebes. Moreno's study of the election found that young, first-time voters and leftist abstainers responded to the apparent manipulation of information by the PP government and mobilized to vote for the PSOE. The high voter turnout was not the highest in Spain's history, but it was on par with other elections of great importance in 1977 (first election after Franco), 1982 (first election after initial transition), and 1996 (first conservative win). Moreno also studied the impact of 11-M on regional politics with a focus on ETA. He reported that the ETA cancelled a plan to explode four car bombs in Madrid in June 2004, because there remained utmost outrage and revulsion over the 11-M attacks. Then

\footnotetext{
${ }^{96}$ Olmeda, "Framing the 3/11 Terrorist Attacks in Madrid and Electoral Accountability," 17-19.

${ }^{97}$ Ibid., 6.

${ }^{98}$ Ibid., 33-34.
} 
the ETA suffered key losses in October 2004 when France arrested its top leaders. Subsequently, the ETA maintained a low profile. ${ }^{99}$

Teemu Sinkkonen conducted a case study of the political response to the Madrid terrorist attack. In his study, he dissected the poll surveys about those who changed their opinions on the election based on the attack. According to one survey, $21.5 \%$ of respondents said that the attack influenced the elections much more or to a certain extent but only $13.5 \%$ of those who responded that way actually changed their voting behavior. ${ }^{100}$ However, Sinkkonen argued that this was different from most surveys and interviews in which "people do not tend to explain their action through fear or commotion." He brought up differing views on the role of emotion in political decision making by historians Edurne Uriarte and George Marcus. Uriarte interpreted the commotion caused by the attack as "paradoxically" redirected from the terrorists towards a government that was unable to protect its own citizens. Marcus, on the other hand, found that people are "able to act rationally just because they are emotional;" thus emotional responses lead to rationality and that people who are in a negative affective state (emotional mood state of distress or having negative emotions) are "more likely to engage in causal reasoning" about the event causing them to be in that state than those who are in a positive affective state (emotional mood state of pleasurable engagement with the environment or having positive emotions). ${ }^{101}$

Sinkkonen concluded that emotion causes people to search for information as a way of coping with events and that due to the outcome of the complexity of the aftermath of the Madrid train bombings, people found voting to be the best way to "regain their sense of security and avoid fear of future threat." He also found that the structure of government, wherein the winning party forms the government and thus the Prime Minister becomes the figurehead, makes it easier for people to "blame the government alone" if things go wrong. ${ }^{102}$ Another of Sinkkonen's conclusions was that the PSOE would not have won the 2004 election if the terrorist attack had not occurred. However, he also concluded that the terrorists did not cause the PP government to lose the election. Instead, it was a failure of crisis government by the PP. Sinkkonen attributed

\footnotetext{
${ }^{99}$ Luis Moreno, "The Madrid Bombings in the Domestic and Regional Politics of Spain," Irish Studies in International Affairs 16 (2005): 67-72.

${ }^{100}$ Teemu Sinkkonen, "Political Responses to Terrorism: Case Study on the Madrid Terrorist Attack on March 11, 2004, and Its Aftermath" (PhD diss., University of Tampere, 2009), 203-204.

${ }^{101}$ Sinkonnen, "Political Responses to Terrorism," 204-209.

102 Ibid., 214.
} 
the failure to Aznar's exclusion of opposition political parties from the crisis government. The excluded opposition quickly found cause to question the government's reports and to obtain the support of the media in appealing to public emotions. Once the public saw that the information flowing from the PP government was not congruent, the response became angry and networks mobilized in protest. Sinkkonen also found that the PSOE may not have won the election if they had supported Aznar in the Iraq War. The voters needed a credible foreign policy option to vote for PSOE. Aznar and the PP government failed to anticipate the highly emotional reaction of the people following the shock of 11-M. ${ }^{103}$

Among the research articles about the concept of "two Spains," Sebastiaan Faber and Felipe Sahagún have noted that the concept of a binary Spain has remained present in Spanish historiography and society. ${ }^{104}$ However, Santos Juliá who has published extensively on the subject of "two Spains" has more recently surprisingly stated that the concept of "two Spains" may be disappearing. ${ }^{105}$ He bases this observation on the loss of the Spanish traditions of intellectuals publishing competing historical essays and for not engaging in public speaking. Instead, Spanish intellectuals are more similar to other Western intellectuals and are publishing in narrower academic journals, but also in the press. Regardless of Juliá's recent statements, the long-running historical controversy about the concept of "two Spains" is clearly continuing in the political sphere. This controversy will be partially addressed by considering next the historiographical highlights of literature regarding the "two Spains" and its relation to the aftermath of 11-M.

Santos Juliá's book, Historia de las dos Españas, published in 2004 is one of the major studies on the concept of "two Spains." conservative, reactionary, and opposed to any change that would in the slightest way transform the nation; the other is reformist, progressive, and eager to engage in change. He acknowledged that many other countries are also split this way, but he argued that Spain is exceptional in this regard, mostly because of the role of the Catholic Church in the state. He supported his argument by mentioning Article 12 of the first (1812) Spanish constitution. This article stated

\footnotetext{
103 Sinkkonen, "Political Responses to Terrorism," 215-218.

${ }^{104}$ Sebastiaan Faber, "The Debate about Spain's Past and the Crisis of Academic Legitimacy: The Case of Santos Juliá," Colorado Review of Hispanic Studies 5 (Fall 2007): 168-169; Sahagún, "Leaders of a Divided Spain."

${ }^{105}$ Faber, "The Debate about Spain's Past," 165-167.

${ }^{106}$ Santos Juliá, Historia de las dos Españas (Madrid: Taurus), 2004.
} 
"the religion of the Spanish nation is and will forever be Catholic, Apostolic and Roman, the only true religion." 107 The Spanish constitution of 1876, which restored the monarchy, has similar language, but this language was eliminated by the Second Republic constitution of 1931 and the current 1978 constitution separated church and state. Juliá also referenced a speech by Cardinal Antonio Maria Rouco Varela, the Archbishop of Madrid, who linked Spanish identity to the Catholic religion. Another of Juliá's arguments was that Spain suffered a huge departure of intellectuals following the Civil War, which only began to be replaced in the next generation and which further strengthened the hand of the Catholic Church during the Franco regime. A summary of Juliá's arguments are the key issues in Spain are national identity and exclusive nationalism and that the concept of "two Spains" is a bipolar metaphor for reality.

In addition to his academic work, Juliá is a political columnist for El País, the leading left-leaning newspaper in Spain. At the one year anniversary of 11-M, he wrote an article about the reaction of the PP to the attacks. ${ }^{108}$ He stated that the purpose of Aznar's first speech after the PP defeat in the election of March 14 was to erode and undermine the legitimacy of the Socialist win. In the words of Juliá: “Their purpose is evident: eroding, undermining the legitimacy of the triumph of the Socialists in those [past] elections." ${ }^{109}$ He continued by arguing that the PP leaders had a strategy to cast doubt on the perpetrators of 11-M by alleging that there was a conspiracy involving a collusion between the Socialists and ETA with the terrorists so that the Socialists would win the election. Juliá additionally noted that as an opposition party, PP had failed to offer a single idea about what to do in the new situation following 11-M.

Sebastiaan Faber has authored many relatively recent research publications about memory related to the Spanish Civil War. One of his papers, "The Debate about Spain's Past and the Crisis of Academic Legitimacy: The Case of Juliá Santos," discussed the concept of "two Spains." ${ }^{110}$ Faber argued that because of the highly polarized rhetoric in Spain, the concept of "two Spains" was still active. He also labeled the concept as the "Spanish problem" because opinion leaders continued to "view the Spanish nation metaphorically as a collective body

\footnotetext{
107 “Consitución Política de la Monarquía Española promulgada en Cádiz a 19 de marzo de 1812,” Capítulo 2, Artículo 12. Translated by me. Original line in Spanish: "la religión de la nación española es y será perpetuamente la católica apostólica y romana, única religión verdadera."

108 Santos Juliá, “Un año de oposición,” El País, May 1, 2005.

109 Juliá, "Un año de oposición.”; Translation by me. Original text: "Su propósito es evidente: erosionar, socavar la legitimidad del triunfo de los socialistas en aquellas elecciones."

${ }^{110}$ Faber, "The Debate about Spain's Past," 165-190.
} 
suffering from some physical or psychological ailment."111 He supported his argument by mentioning the caustic duel between the PP and PSOE political parties, the loss of rationality, the lack of mutual respect in public discourse. On the other hand, Faber praised the openness of idea creation. Additionally, he lamented the polarization of the media, which has negatively impacted independent journalism. Faber summarized the bipolar nature of Spain by stating: "Still, the Spanish crisis seems particularly severe, and its symptoms particularly pronounced. Another trait that distinguishes the polarizing process in Spain from that of the rest in the West is the fact that Spain's political discourse is strangely haunted by history, and seemingly prone to an obsessive rehearsal of past conflicts. $" 112$

Nicholas Manganas has presented las dos Españas (liberal and conservative Spains) as a prevalent social narrative in Spain. ${ }^{113}$ Manganas described "liberal" Spain as having been "accorded the values of the French Revolution" and as being "anti-monarchical and antiregionalist."114 He said that in the popular historical narrative, the cause of the Spanish Civil War was the deep difference in the two ideologies of las dos Españas. The popular narrative continues by generalizing the Franco regime as having been the height of "conservative" Spain and that it was the second point of following traditionalist precepts, which proved to be "illegitimate, oppressive, and undemocratic." Manganas argued that although the narrative assumes that every Spaniard can be placed on one side or the other, the narrative is potent and real to the families who lost relatives in the Civil War. According to Manganas, one social narrative from the Franco regime that continues to the present time is the claim that the regime "was restoring 'order' to Spain after the chaos that ensued with the liberal Second Republic. Liberal Spain was thus accorded the values of 'disorder' - a narrative that has remained dominant to this day in much of the Spanish mass media." ${ }^{115}$ He additionally argued that the "pact of silence" diminished the concept of las dos Españas with the idea that Spain was a peaceful and democratic nation. Then following 11-M, Manganas suggested that the narrative of

\footnotetext{
${ }^{111}$ Faber, "The Debate about Spain's Past," 169.

112 Ibid., 170.

${ }^{113}$ Manganas, "Mass-Mediated Social Terror," 1-14.

114 Ibid., 4.

115 Ibid., 5.
} 
las dos Españas returned. ${ }^{116}$ He concluded by maintaining that this narrative is entrenched in Spanish memory because of previous social terror. ${ }^{117}$

\section{Controversies}

As the analysis of the immediate aftermath timeline of 11-M and historiography indicate, the security crisis following the national trauma of the attacks was politicized. Consequently, several controversies developed out of the aftermath of 11-M, some of which continue to today. This section explores the following major controversies:

- What caused the 2004 election outcome of an unexpected PSOE win? Was it the terrorism attack or was it the government response to the attack?

- Were the protests after the 11-M attack an emotional reaction or were they politically motivated?

- Why was ETA blamed for the attack? Who were the perpetrators?

- What were the motives behind the terrorist attack?

This section also discusses in what way and to what extent conspiracy theories shaped the discourse on the 11-M attack. These controversies and conspiracy theories were cultivated by the differing reports between the government and the investigation teams as well as the conflicting reports within the media over the responsibilities behind the attacks. There also was not a clear motivation for the attackers, whoever they were, and thus led to rumors of a government cover-up. The first major controversy which will be explored is that of the outcome of the election.

\section{Election Outcome}

Following the 11-M attack, the election turned against the incumbent Partido Popular party and their leftist rivals won the election. But was it the terrorist attack that caused the PSOE to win the election or was it the government response to the attack that caused the PP to lose the election? This had been a major talking point for politicians and political commentators as well as the ordinary Spanish people in the decade following the Atocha attack. Most people tend to

\footnotetext{
${ }^{116}$ Manganas, "Mass-Mediated Social Terror," 7.

117 Ibid., 14.
} 
agree that the political demise of Aznar's party (Partido Popular, PP) was not due to the attack itself but was due to the response the government had to it. ${ }^{118}$ The "fixation" of the Interior Minister, Acebes, about ETA's responsibility for the attacks was because the party knew that people would rally behind them in the face of an attack by ETA but would criticize them for their policies in Iraq if it turned out to be an attack from an Arab source. As an outcome of the Socialist victory, Zapatero had a massive responsibility put on his shoulders and he needed to overcome the blunderings of the PP and the past problems within the Socialist party during his leadership. ${ }^{119}$ Zapatero certainly shouldered the responsibility when he took Spanish troops out of Iraq. This sentiment was also echoed in American observations after the attack took place.

A Senior Fellow of U.S. Foreign Policy, Philip H. Gordon, observed in his testimony to the Senate Committee on Foreign Relations in late March of 2004 about the attack that "there can be little doubt that the March 11 attacks influenced the outcome of the election" as the polls showed a clear victory by the PP the week before the election. Gordon continued in his testimony that "the Aznar government appears to have concluded that an ETA attack would be politically helpful... whereas an al Qaeda attack might hurt the government..."120

Victor de la Serna contrasted the electoral effects of the 2004 Madrid bombings and the effects of the 2005 London attacks on U.K. politics. The events in Madrid caused "three venomous days of recriminations about the terrorist actions and their perpetrators" and the favorable lead the incumbents had (despite the overwhelming opposition to the Iraq War) evaporated. ${ }^{121}$ In contrast, the government in the U.K. did not experience upheaval as they were not facing an impending election. As de la Serna concluded, the political infighting in Spain "poisoned" the political atmosphere and provoked an ever-widening social divide between the left and the right which led to the vanishing of the "horror" of 11-M in the few years after the event. $^{122}$

\footnotetext{
${ }^{118}$ Paddy Woodworth, “Spain Changes Course: Aznar's Legacy, Zapatero's Prospects,” World Policy Journal 21, no. 2 (Summer, 2004): 20.

${ }^{119}$ Woodworth, "Spain Changes Course," 21-23.

${ }^{120}$ Philip H. Gordon, "Madrid Bombings and U.S. Policy," Brookings Institute, Testimony to Senate Committee on Foreign Relations, March 31, 2004.

${ }^{121}$ Victor de la Serna, "Madrid's Vanished Horror," Guardian, Madrid, July 8, 2005, accessed September 14, 2015, http://www.theguardian.com/world/2005/jul/08/spain.terrorism/print.

${ }^{122}$ Serna, "Madrid's Vanished Horror."
} 
This divide between the political parties also spread into a divide between media outlets and a disconnection between the government and the press. In the hours and days following the attacks, the press headlines changed depending on the information available to change the framing of the attack from one of domestic terror to that of international extremism. ${ }^{123}$ The change in blame can be seen primarily in the leftist and international coverage of the attack as well as the changes in the government response to the attack. The first few hours after the attack saw overwhelming support for the blaming of ETA (even the Basque nationalist party joined in the blame) and this belief in the perpetrators of the attack was reinforced by the news conference held at 1:00 PM on the $11^{\text {th }}$ of March by the Minister of the Interior confirming that ETA was suspected of carrying out the attack. ${ }^{124}$ In the days that followed, the press began to have different viewpoints on the attacks and the perpetrators. The authenticity of the government's blame for the attack was called into question by leftist newspapers/organizations such as El País when, at the same time, the rightist news organizations (such as El Mundo) generally backed the governmental response and accused the left of "manipulating by distorting facts." 125 As questions arose around whether or not Aznar's government was telling the truth, protestors demonstrated across Spain in the days leading up to the election.

However, other sources have cited the overwhelming majority of Spaniards who opposed the Iraq invasion as the main reason that the PP lost the 2004 election. For example, a March of 2003 poll of Spaniards showed that as many as ninety-two percent of Spaniards opposed the war in Iraq. This included seventy-one percent of those who had voted for the PP but were against involvement in the war. ${ }^{126}$ Tony Karon of Time Magazine argued that the outcome of the election, had it been held a year before, might have had a similar result as around ninety percent of voters opposed the support for the war and that the attacks "simply put the Iraq issue back at center stage." ${ }^{\prime 27}$ In this view, the bombings did not change the existing opinion of the Spanish voters on the issue of the involvement in Iraq but it spurred them to the voting booths to express

\footnotetext{
${ }^{123}$ María-José Canel, “Communicating strategically in the face of terrorism: The Spanish government's response to the 2004 Madrid bombing attacks," Public Relations Review 38 (2012): 216-217.

${ }^{124}$ Canel, "Communicating strategically," 216.

125 Ibid., 217.

126 “El 92\% de los Españoles se Opone a la Guerra Contra Irak,” Clarín.com, March 29, 2003, http://edant.clarin.com/diario/2003/03/29/um/m-537495.htm.

${ }^{127}$ Tony Karon, “Did al-Qaeda Change Spain's Regime?” Time, March 15, 2004, accessed July 15, 2014, http://content.time.com/time/printout/0,8816,601306,00.html.
} 
their views and to elect new leaders who would see them leave Iraq. ${ }^{128}$ The political change following 11-M deepened the divide between the two political parties and created a more negative atmosphere in the political and public spheres and led to parliamentary inquiries. These inquiries were not only focused on the attackers but also on the performance of the cabinet during the time of the attack for not having "prepared better for Islamic terrorist actions" and for misleading the public on who to blame for the attack. ${ }^{129}$

The desire to change the leadership of the country as the driving force for the PP defeat was echoed in other articles by journalists and historians. One argument was the increasing support for the PSOE following the official start of campaign. Raj S. Chari discussed the two major reasons for the rise of the Socialists as being restructuring of a "new 'generation' of socialists" as a way to distance the party from the corrupt Socialist politicians of the past and the development of policies to help poor or younger Spanish citizens who had historically had issues in entering the property market, as well as policies promising greater European integration and the removal of troops from Iraq. ${ }^{130}$ These shifts in policy along with the missteps of the PP prior to the start of the elections and before the Madrid train bombings led to some observations of how the Socialists won the election. However, the polls do not support this argument.

There are other historians who have argued that it was a combination of factors which led to the downfall of the PP and the rise of the PSOE in the election. There are three factors which this group of historians predominantly point to as the reason for the shift in the direction of the public's vote. The first was the continued insistence that ETA was behind the attack even after confirmation by the leadership that an Islamic group was behind the attack. The second was the public's mistrust of the party which had been building even before the attack occurred. The third was the resurgence of antiwar views as many saw the attacks as punishment for the involvement in Iraq. ${ }^{131}$ There is another argument which furthers the multi-causality of the election results as based off of emotional responses by the electorate towards the attack and the government's response.

\footnotetext{
${ }^{128}$ Karon, "Did al-Qaeda Change Spain's Regime?"

${ }^{129}$ Serna, "Madrid's Vanished Horror."

${ }^{130}$ Raj S. Chari, “The 2004 Spanish Election: Terrorism as a Catalyst for Change?" West European Politics 27, no. 5 (November, 2004): 956.

${ }^{131}$ William Rose, Rysia Murphy, and Max Abrahms, "Does Terrorism Ever Work? The 2004 Madrid Train Bombings,” International Security 32, no. 1 (Summer, 2007): 188.
} 
On April 23, 2004, Spanish troops withdrew from their international brigade in Iraq and headed home. Zapatero had completed his campaign promise to get Spanish troops out of Iraq. Though he had removed the Spanish forces from combat, Zapatero was still committed to fighting terrorism. In a September 21, 2004, speech to the United Nations General Assembly, he thanked the other member nations for their support following the 11-M bombings and stated that "nothing justifies terrorism" and that "terrorism is insanity and death and, regrettably, there will always be fanatics who are ready to kill to impose their insanity through force." ${ }^{132}$ He continued by discussing terrorism as the "seed of evil," a seed that could not take root in a society of "justice, well-being, freedom and hope" but could only take root "if it lands on the soil of injustice, poverty, humiliation, and despair."133 He also addressed the reasons for removing Spain from the war. He stated that the majority of Spaniards who were against the war "were not persuaded by the reasons given by those who promoted the war." Zapatero also stated that "winning the war would be much easier than winning the peace" and that Spain would contribute to the restoration of full sovereignty and independence of a democratic Iraq. ${ }^{134}$ As such, he contrasted his government to that of Aznar's and the desire to no longer have troops in Iraq to begin the rebuilding process of the Iraqi government. It was with this mentality, at least publicly, and the pressure of the Spanish people to leave the war that caused Spain to no longer be a member of Operation Iraqi Freedom. Therefore, it can be said that the 11-M terrorists achieved one of their major objectives, although Zapatero was also meeting his pre-election promise.

Election results for the 2004 general election for the Congress of Deputies when compared to the 2000 election are indicative of what transpired following 11-M. PSOE gained 3.1 million more votes and PP lost 550,000 votes versus the 2000 election. All other parties gained 120,000 votes with most of the gain by the regional parties: the Catalonia Republican Left (ERC) and the Basque National Party (PNV). Overall, the voter turnout increased by 2.67 million voters which nearly matches the PSOE increase. The overall voter turnout was 75.7\%, which was $6.9 \%$ points greater than in $2000 .{ }^{135}$ Clearly, the PSOE won because of the greater

\footnotetext{
132 José Luis Rodríguez Zapatero, "Statement by the President of the Government of Spain, Mr. José Luis Rodríguez Zapatero, at the $59^{\text {th }}$ Session of the United Nations General Assembly," New York, September 21, 2004.

${ }^{133}$ Zapatero, "Statement by the President of the Government of Spain."

134 Ibid.

${ }^{135}$ Olmeda, "Framing the 3/11 Terrorist Attacks in Madrid and Electoral Accountability," 27-28.
} 
voter turnout and not because the PP had a vote reduction of 550,000 votes. Therefore, the question becomes what motivated the greater than expected voter turnout? Was it fear that caused the overturning of the PP government?

\section{Protestors' Motivation}

As was noted in the 11-M aftermath timeline, demonstrators took to the streets of most cities in Spain in the period between the bombings and the election. The first demonstrations of March 12 were initially called by the PP government to rally support and to express indignation for the terrorist attack. The turnout on March 12 was massive with about twenty-five percent of the population of Spain demonstrating, which would be the equivalent of about eighty million people in the United States. This initial, incredible turnout was generally in support of the government, but rumors had begun that maybe the terrorists were not ETA and some demonstrators began questioning the government narrative, especially in Madrid and Barcelona. Giles Tremlett, who was in Madrid the night of March 12, stated that over a million people packed the streets during a steady rain and that the crowds became increasingly angry as the demonstration progressed. The anger, which was initially against ETA, became more directed at the government with anti-war signs and ringing cries of "Who was it?"136 Continuing large demonstrations on March 13 and March 14 were not called by the government and these demonstrations were questioning the government's veracity. Many of these demonstrations targeted PP offices.

Tremlett attended the March 13 demonstrations at the PP's Génova Street Headquarters in Madrid. He said that when he arrived at ten minutes to six, there were only a handful of demonstrators and more than a dozen journalists and photographers present. At precisely six, the demonstration "materialised out of thin air" with hundreds, then thousands of people arriving. Within thirty minutes, 5,000 people were present angrily shouting "We want the truth, before we vote" along with continued cries of "Who was it?" The demonstration continued throughout the night into Election Day. Tremlett stated: “There was no silence. The crowd howled... It was remarkable, given the tension and the anger, that there was no violence."137 What motivated

\footnotetext{
${ }^{136}$ Giles Tremlett, Ghosts of Spain: Travels Through Spain and Its Silent Past (New York: Walker \& Company, 2007), 238.

137 Tremlett, Ghosts of Spain, 242-243.
} 
such large demonstrations in Spain in the immediate aftermath of 11-M? Why did the PP lose the election?

Many say that the initial reaction to a terrorist attack is fear. Others say that the reaction is anger. Olmeda discussed a "causal path" in the aftermath of 11-M that resulted in the PSOE electoral victory. He suggested:

The main effect is fear; this is the climate for blaming the government instead of blaming the terrorist. As we have seen before, the period of the PP government with an overall majority brought an increased polarisation of the electorate. In this milieu, the terrorist attacks were the necessary condition for an increasing turnout (a result of the attacks plus the demonstrations on March 12); for a transformation of the expressive vote for the postcommunists into a [sic] instrumental vote for the socialists, an increase of the 'useful' vote, especially in the sectors mobilized by the flash mobs and for the constitution of the populist antiwar frame in the master frame to attract younger, new voters nurtured by the cycle of protest against the PP and its policies in different sectors. ${ }^{138}$

Manganas likewise attributed the reaction to 11-M as fear. Regarding the period between the attack and the election, he stated: "Those three days constituted a unique form of social terror unleashed upon the Spanish people.” Furthermore, he stated that the PP government endeavored to "turn a moment of fear into one of political gain by using a particular narrative that backfired."139 He was referring to the "blame ETA" narrative. Additionally Manganas discussed that the media's narratives in the aftermath of 11-M were not neutral and that the narratives had an effect on their audiences. ${ }^{140}$ The aftermath timeline presented in the beginning of this section strongly supports the media influence particularly with radio station Cadena Ser broadcasts and with editorials in the two major newspapers El País and El Mundo. Manganas summarizes with a general statement about the historical record: "The accepted narratives in the aftermath of the 11 March attacks is that the PP government was voted out of government because it 'manipulated' the flow of information by insisting that ETA was responsible.",141

\footnotetext{
${ }^{138}$ Olmeda, "Framing the 3/11 Terrorist Attacks in Madrid and Electoral Accountability," 28-29.

${ }^{139}$ Manganas, "Mass-Mediated Social Terror," 2.

${ }^{140}$ Ibid., 9.

${ }^{141}$ Ibid., 12.
} 
Philip H. Gordon, a U.S. foreign policy expert, testified to the U.S. Senate Committee on Foreign Relations on March 31, 2004, about the Madrid bombings and the setback caused by the defeat of Spain's Popular Party. He was adamant in his testimony that any conclusion that Spain had opted for appeasement with terrorism by withdrawing from Iraq was misplaced and he warned that wrong policy decisions could give the terrorists what they wanted, which was to undermine cooperation. Gordon provided details to support his belief that Spanish voters did not give in to terrorism. In particular, he mentioned poll data. He said that polls of March 7, the final polls before the election, indicated that the PSOE trailed the PP thirty-eight percent to fortytwo percent. He said it was not likely that the PSOE could have turned around opinion within a week to win forty-four percent to thirty-eight percent were it not for the attacks. He stressed that voter turnout of Spain's thirty-five million voters rose to seventy-seven percent, compared to just fifty-five percent four years earlier, and that two million of the new voters were first-time voters. He attributed the voter turnout to a strong emotional response, some of which was opposition to the Iraq war, but mainly he said it was anger at the government's handling of the 11-M crisis. He presented polling data taken after the election which found that at least sixty-seven percent of the Spanish people believed that the government had manipulated information. He further stated that the historical stand of both Spanish parties against terrorism was a convincing argument that appeasement was highly unlikely. ${ }^{142}$

Woodworth had a different perspective on the PP government reaction to the 11-M attacks. He believed that Aznar's fixation on ETA blame for the attack was probably a calculated strategy. Aznar was counting on the Spanish people rallying behind the government for an ETA attack as the people had done previously. However, if the attack was Al Qaeda related, Aznar was likely thinking that the PP would be punished in the election due to his government's participation in the Iraq war, which was opposed by ninety-two percent of the Spanish people, including seventy-one percent of PP voters. ${ }^{143}$ Regarding the demonstrations the evening of March 12, Woodworth stated: "With Friday night's enormous demonstrations, the government found that rage against its handling of information about the bombings was palpable. People were not demonstrating against ETA, they were chanting, 'Who was it?' and 'Your war, our blood!' Among the thousands of messages left at the bombing sites and at town halls, many

\footnotetext{
${ }^{142}$ Gordon, "Madrid Bombings," 1-3.

143 "El 92\% de los Españoles."
} 
blamed Aznar personally for the attacks." Woodworth also mentioned a London Times interview of Aznar in April 2004 in which Aznar said "that it was an 'infamy' to suggest that he had played politics with terrorism."144 Woodworth had several conclusions about the 11-M aftermath, which he termed as being positive. His first conclusion was about the maturity of the Spanish people, who responded quickly to a rapidly changing political situation. He stated: "Those who say Spaniards voted out of fear simply do not know Spanish democracy, which has not been intimidated by 30 years of bombings and shootings by ETA." Secondly he acknowledged that the Spanish police and intelligence services conducted a professional investigation of the 11-M bombings, quickly tracked down the likely bombers, and avoided being misled by the government. ${ }^{145}$ One could say that their findings changed the election. Woolworth also summarized the ETA situation by predicting that ETA was likely to announce a cease-fire because the "Madrid bombings have shattered most of whatever support remained for 'armed struggle'.,146

The above examples of 11-M historiography debated about whether fear or anger caused the large demonstrations following the 11-M attacks and the high voter turnout are inconclusive. A broader examination may be enlightening. Terrorism expert Max Abrahms has looked into the Madrid bombings to determine if the outcome of this attack was an anomaly, because the terrorists achieved their objective of forcing the withdrawal of Spanish troops from Iraq. Abrahms has shown that terrorists rarely achieve their objective when targeting civilians. He has said that normally the exact opposite occurs since the usual response is for the attacked nation to go on the offensive and not make concessions, with the electorate moving to the political right. ${ }^{147}$ As the previously presented timeline indicates, this typical response occurred for less than one day following 11-M; then the election tilted to the political left. However, Spain followed the norm in response to ETA attacks. During Aznar's two terms as President of the Government, most Spaniards supported his policy of "zero tolerance" for ETA attacks. This policy was so effective that by the end of his administration, ETA membership had dropped below a hundred. Therefore, what interrupted the normal response following 11-M? According to the Abrahms' model, the PP should have won the election.

\footnotetext{
${ }^{144}$ Woodworth, "Spain Changes Course," 21.

145 Ibid., 22.

146 Ibid.

${ }^{147}$ Max Abrahms, “Why Terrorism Does Not Work,” International Security 31, No. 2 (Fall 2006): 75-76.
} 
Sidney Tarrow, in his book Power in Movement: Social Movements and Contentious Politics, presented how social movements generate political power through contentious collective action and political opportunity. He argued that contentious collective action is the basis for social movements, protests, riots, strike waves, and insurgencies; and that actions may be brief or sustained. Contentious collective action can bestow power on ordinary people by challenging authorities in conflicted ways. ${ }^{148}$ Additionally, he argued that political opportunity is a necessary condition for contentious politics to arise and that opportunities must be available for mobilization and exploitation through structures and networks. He summarized by stating: "People engage in contentious politics when patterns of political opportunities and constraints change, and then by strategically employing a repertoire of collective action, creating new opportunities, which are used by others in a widening cycle of contention."149

To answer why the Spanish electorate tilted to the political left in a few days, the Tarrow arguments may have utility. To determine if the arguments apply, the questions of whether or not the demonstrations became contentious and were organized to become collective and whether or not political opportunity existed are key. Tremlett was a witness to the Madrid demonstrations and he said that the government called demonstration of March 12 became increasingly angry as the evening progressed. Tremlett also said that the demonstrations in regional areas “already angry with Aznar," particularly Barcelona and Bilbao, were especially tense. ${ }^{150}$ Olmeda stated that at the Barcelona demonstration, several PP politicians were attacked. ${ }^{151}$ Tremlett likewise said that the Madrid demonstrations of March 13 and 14, which followed the rumors, newspaper, editorials, and radio broadcast of potential Al Qaeda involvement were tense with loud and angry crowds. ${ }^{152}$ Olmeda described the demonstrations of March 13 and 14 as being "micro-mobilisations (flash mobs)."153 Based on the Tremlett and Olmeda reports, the demonstrations became contentious, but were they organized to become collective?

\footnotetext{
${ }^{148}$ Sidney C. Tarrow, Power in Movement: Social Movements and Contentious Politics (Cambridge University Press, 1994), 7-8.

149 Tarrow, Power in Movement, 26-29.

150 Tremlett, Ghosts of Spain, 238-239.

${ }^{151}$ Olmeda, "Framing the 3/11 Terrorist Attacks in Madrid and Electoral Accountability," 23.

152 Tremlett, Ghosts of Spain, 242-243.

${ }^{153}$ Olmeda, "Framing the 3/11 Terrorist Attacks in Madrid and Electoral Accountability," 25-27.
} 
Olmeda named several organizations and internet sites of different ideologies involved in the mobilization of the "flash mob" demonstrations. He asserted that activists at these networking organizations planned the demonstrations of March 13 and 14 through messages on their sites and through cell phone text messaging. ${ }^{154}$ Likewise, Tremlett mentioned the use of cell phone text messaging to organize the demonstrations, which he labeled as a new political phenomenon, "the instant text message demonstration." He said that his partner's cell phone received this message: "Aznar smelling of roses? They call this the day of reflection and Urdaci is working? Today, the $13^{\text {th }}$, at 6 p.m., PP HQ 13 Génova St., without parties. Silence for the truth. pásalo!" Tremlett explained that Urdaci was the head of news at the state broadcaster RTVE. He also explained that pásalo means "pass it on" in English. He said that these chain text messages became known as "pásalo messages." In a few hours, demonstrations were arranged at PP offices throughout the country. ${ }^{155}$ Jill Robbins published similar information about how the demonstrations were organized through emails and texting. She said the "protests demonstrated the existence of a politicized populace with a sophisticated sense of the workings of language, technology, and the media image, resistant to political commonplaces, and suspicious of government's motives." Robbins observed that the network society and the media had quickly unraveled the government's narrative about blaming ETA and that the PP's loss of message was a major factor in their election defeat. ${ }^{156}$ Therefore the demonstrations were organized and hence collective, but was political opportunity present?

Initially, the 11-M attacks provided political opportunity for the PP, since the norm, according to Abrahms, was for the population to rally around the government. As the aftermath timeline event analysis reflects, within three hours of the attack, Aznar was already moving to take advantage of the situation by calling for support demonstrations on March 12 under a politically charged banner headline of "With the victims, with the Constitution, for defeating terrorism," which resulted in at least the Catalan prime minister objecting to including the controversial Constitution of 1978 in the slogan. However, as the government story of ETA responsibility began to unravel, the Opposition began to take advantage of the situation. According to the aftermath timeline, by the morning of March 12, Zapatero was raising the

\footnotetext{
${ }^{154}$ Olmeda, "Framing the 3/11 Terrorist Attacks in Madrid and Electoral Accountability," 30-31, 37.

155 Tremlett, Ghosts of Spain, 241-242.

156 Jill Robbins, "Memorials, Shrines, and Umbrellas in the Rain: Poetry and 11-M," Studies in $20^{\text {th }}$ \& $21^{\text {st }}$ Century Literature 36, no. 2 (Summer 2012), Article 14: 392-393.
} 
question of potential Al Qaeda involvement and when the PSOE issued their final statement before Election Day, they accused the government of lying. In the same statement, the PSOE denied organizing the demonstrations. Hence, the PP government and the Opposition saw political opportunity in the aftermath of 11-M related to the election. What is astounding is how the opportunity swung from the PP government to the Opposition within two days as the PP government mishandled their response to 11-M.

An assessment of psychological distress in the general Madrid population was conducted by Juan J. Miguel-Tobal et al in the period of one to three months following the 11-M attacks. ${ }^{157}$ The study was carefully structured to be fully representative of the Madrid population and to oversample the population who lived within one kilometer of the bombings areas. ${ }^{158}$ The study found that only 2.3 percent of the Madrid population suffered post-traumatic stress disorder (PTSD) related to the bombings. Higher PTSD rates were found in people who were directly exposed to the bombings: direct witness -8.3 percent PTSD rate, friend or relative killed -6.1 percent, rescue involvement -3.6 percent. The study also found that 11.7 percent of the respondents suffered symptoms of panic attack during or soon after the bombings, which indicated that a relatively small proportion of the Madrid population was seriously stressed and fearful following 11-M. ${ }^{159}$

Research by Jennifer Lerner and Dacher Keltner supports the argument that anger caused the large demonstrations following 11-M. They found that fear and anger have opposite effects on risk perception, judgement, and actions. Fearful people are risk adverse and make decisions based on pessimism; whereas angry people are risk seeking and make decisions based on optimism. Surprisingly, angry people are similar to happy people in risk taking. Hence, fearful people were not likely to have participated in the widespread demonstrations, but angry people would have been driven to take action. ${ }^{160}$

In summary, all facets of Tarrow's theories about contentious collective action and political opportunity were present in the immediate aftermath of 11-M. The social movement

\footnotetext{
${ }^{157}$ Miguel-Tobal et al, "PTSD and Depression After Madrid," 69-80.

158 Ibid., 70.

${ }^{159}$ Ibid., 74.

${ }^{160}$ Jennifer S. Lerner and Dacher Keltner, "Fear, Anger, and Risk," Journal of Personality and Social Psychology 81, no. 1 (2001): 146-159.
} 
swung the election to the political left because of the turnout of new voters, who were motivated by the media and social messaging about the government not telling the truth. Was it fear or anger that drove the demonstrations and social movement? Tremlett was a witness and he saw anger. Woodworth had a strong point in his statement that the Spanish people had not been intimidated by thirty years of ETA terrorism and had not voted out of fear. Also the meaning of "contentious" as being argumentative, especially heated or impassioned, generally implies the presence of anger. The data from the Miguel-Tobal et al psychological study indicated that at least eighty-eight percent of the Madrid population did not have a serious fear response to 11-M. Furthermore, the study found that nearly half of the PTSD reported symptoms were among people with low social support, who were less likely to have participated in the demonstrations. ${ }^{161}$ Finally, the Lerner and Keltner research confirmed that generally fearful people are risk adverse and were not likely to have participated in the demonstrations. Therefore it is reasonable to conclude that anger against the terrorists and against the government and not fear was the motivating factor for the demonstrations and social movement which drove the greater voter turnout.

\section{$\underline{\text { The Perpetrators }}$}

As evident in the delay between the government blaming the attack on ETA and the subsequent shift to put blame on international Islamist extremism, differences in opinion on who conducted the attack were debated for over a decade after the attacks' conclusion and into the present time. There are conspiracy theories that the attack was a cover-up from both the left and the right in the press and in politics. But just who conducted the attacks on 11-M? This section looks at the differing opinions over who conducted the train bombings.

The majority of historians as well as leftist politicians and press place the responsibility for the attack on Islamist extremists who had outside support from terrorist organizations, as evident from the police reports in the days and months following the attack. However, there still is disagreement within this camp as to whether or not the terrorists were "homegrown" or whether they had ties to the central Al Qaeda leadership. Some news articles labeled the terrorists as “...inspired by al-Qaeda’s call to reconquer the lands which were once Islamic...”

\footnotetext{
${ }^{161}$ Miguel-Tobal et al., "PTSD and Depression After Madrid," 74.
} 
but that there were "relatively few signs of any direct contact or training" from the main leadership of Al Qaeda. ${ }^{162}$ However, there are also articles which detail the terrorists as having direct ties to Al Qaeda leadership primarily through Abu Musab al Zarqawi as he was potentially the mastermind for the attack. ${ }^{163}$ One of the historians who believes that the terrorist network responsible for 11-M had international connections is Fernando Reinares, who is considered a Spanish terrorism expert and has published extensively on the network and the leaders who targeted Spain.

In 2009, Reinares examined the bombings by providing an analysis of the terrorist network involved and the process of radicalization among the members of the network. He argued that analyzing the network helped to provide a "deeper understanding of terrorist radicalization" and that the people responsible for the train bombings were radicalized at different times, in different places, and through different means. ${ }^{164}$ He concluded that the network was not "homegrown" and that, "with one exception," had international connections and did not include people from Spain or Western Europe. ${ }^{165}$ He also concluded that the makeup of the group included those who radicalized before 9/11; after the US-led invasion of Afghanistan, and after the US-led invasion of Iraq. ${ }^{166}$ In 2010, he published an article which tied a Moroccan, Amer Azizi, to central Al Qaeda leaders in Pakistan. Reinares was quoted as saying "There was always speculation that Azizi was the instigator of the attack. Amer Azizi's name appears in 149 of the 271 volumes on the Madrid bombings compiled by Spain's National Court."167

In a 2012 article Reinares explored the role Al Qaeda played in the attack and the likely connection between the central leadership of Al Qaeda and the Madrid network. He showed that Azizi initiated plans for an attack as early as the second half of 2001 and traveled from Pakistan to Spain in 2003 to convey the approval of Al Qaeda for an attack on Spain. ${ }^{168} \mathrm{He}$ concluded

\footnotetext{
162 Gordon Corera, "The Legacy of the Madrid Bombings," BBC News, last modified February 15, 2007, accessed September 4, 2015, http://news.bbc.co.uk/2/hi/europe/6357599.stm.

${ }^{163}$ Robert S. Leiken and Steven Brooke, "Who is Abu Zarqawi?" CBS News, Weekly Standard, last modified May 18, 2004, accessed December 3, 2014, http://www.cbsnews.com/news/who-is-abu-zarqawi/.

${ }^{164}$ Reinares, Fernando. "Jihadist Radicalization and the 2004 Madrid Bombing Network." CTC Sentinel 2, no. 2 (November 2009): 16.

${ }^{165}$ Reinares, "Jihadist Radicalization and the 2004 Madrid Bombing Network," 19.

166 Ibid., 19.

${ }^{167}$ William Maclean, "New Evidence of Qaeda tie to Madrid Blast: Expert," Reuters.com, last modified January 12 , 2010, accessed December 3, 2014, http://www.reuters.com/assets/print?aid=USTRE60B52020100112.

${ }^{168}$ Fernando Reinares, “The Evidence of Al-Qàida’s Role in the 2004 Madrid Attack," CTC Sentinel 5, no. 3 (March 2012): 1-2.
} 
that this connection showed that the "decision to attack Spain and the mobilization of a terrorist network to accomplish this objective were top down processes." ${ }^{\prime 69}$ In a 2014 book, Reinares went into greater detail over the reasoning behind the targeting of Spain for the attack. He examined the train bombings and determined why Spain might have been targeted by the extremists. He argued, similarly to his other works, that Azizi was the man who was most interested in attacking Spain and that he was considering an attack on Spain as early as the autumn of 2001, before 9/11. ${ }^{170}$ Indeed, Reinares concluded that Azizi was the terrorist mainly responsible for the attack and that the Iraq War was not a driving force behind the attack, but provided a "favorable context to suit his [Azizi's] strategy and to leverage an impact."171 It was this grouping of arguments and conclusions by Reinares which differed from much of 11-M historiography, which saw the terrorist cell responsible for the train bombings as leaderless with homegrown motives.

However, regardless of whether or not the terrorists were aligned with the central leadership of Al Qaeda, the terrorist organization was not shy from showing its support of the attacks. A video by the terrorist group, released in 2007, featured the American-turned-Islamist extremist Adam Gadhan praising the destruction wrought by terrorists in the previous six years. He expressed how "proud" Al Qaeda was of the destruction in Madrid and London, as well as that of New York and Washington. ${ }^{172}$

Immediately following the attack, the Aznar government and the opposition were quick to put the blame on ETA for carrying out the attack. This was evident in Aznar's press conference on the day of the attack in which he strongly implicated that ETA was behind the bombings and that, in effect, the strength of the law and the unity of Spaniards would put an end to the terrorists. ${ }^{173}$ Along with this statement, the PP attempted to get a U.N. resolution passed to condemn ETA for the attacks. Spanish diplomats were successful in doing so and, thus, a

\footnotetext{
${ }^{169}$ Reinares, "The Evidence of Al-Qàida's Role in the 2004 Madrid Attack," 5.

${ }^{170}$ Fernando Reinares, ;Matadlos! Quién Estuvo Detrás del 11-M y por qué se Atentó en España [Kill Them! Who was Behind 11-M and Why Spain was Targeted] (Barcelona: Galaxia Gutenberg, 2014), 142.

${ }^{171}$ Reinares, ;Matadlos!, 245.

172 Amanda Figueras, “Al Qaeda Dice Sentirse ‘Orgullosa' de la Destrucción que Afectó a Madrid el 11-M,” El Mundo, August 6, 2007, accessed September 14, 2014, http://www.elmundo.es/elmundo/2007/08/06/internacional/1186414637.html.

${ }^{173}$ Aznar, "Declaración Íntegra."
} 
resolution was quickly passed by a supportive U.N., but which would eventually become a focus of criticism among Spaniards and the international community. ${ }^{174}$

Although the evidence that emerged from the police investigation seemed to overwhelmingly prove that Islamist terrorists were behind the attack, the ousted PP officials as well as right-wing news organizations continued to imply (even over a decade later) that ETA was behind the attack. They sought to show to their supporters, and to the left-wing politicians and the Socialists' supporters, that there had been a cover up by the opposition. There were a series of reports published in El Mundo placing the blame on ETA, on the Socialists themselves, and even on the police. One such conspiracy theory alleged that "Spanish intelligence officials, who were partial to the Socialists, allowed the train bombings to happen to help pave the way for the Socialists to take government" in the March elections. ${ }^{175}$ Even Aznar believed that this could have been a possibility, as he mentioned that he believed that the attacks would still have occurred even if he had changed the election date to a week earlier. ${ }^{176}$ Another conspiracy placed blame on the police for planting evidence. Foreign affairs spokesman for the PP, Gustavo de Arístegui, stated two days after the attack that "Certain opposition parties are trying to use Al Qaeda because of the Iraq war simply to win an election... I think it's repulsive." He also stated, in reference to the Koranic tape discovered in the van, that "I cannot picture a radical Islamist with a beginner's tape. Normally it would be someone with more sophisticated material. Anybody could have planted a tape there."177 These conspiracy theories either reflect true disbelief in the police investigation or they are a fabrication to sway public opinion about the election outcome and the sudden unexpected defeat.

In late 2004 into early 2005, a parliamentary panel which investigated the train bombings took aim at the government's response to the attack. During a portion of testimony to the panel, Aznar implicitly stated his support for the allegation that ETA was the behind the attack. He said "there is absolute proof that shows... a connection between Eta [sic] terrorists and Islamic terrorism" as well as "what is strange to me is that there is no will to investigate it. I am one of

\footnotetext{
${ }^{174}$ Patricia Bezunartea, José Manuel López, and Laura Tedesco, "Muslims in Spain and Islamic Religious Radicalism," MICROCON Policy Working Paper 8, Brighton: MICROCON, (May 2009), 13.

${ }^{175}$ Natalia Junquera, "Victims Put Aside 10 Years of Difference over 11-M to Remember Loved Ones," El País in English, Madrid, last modified March 12, 2014, accessed September 4, 2015, http://elpais.com/m/elpais/2014/03/12/inenglish/1394625516_511144.html.

${ }^{176}$ Junquera, "Victims Put Aside 10 Years of Difference over 11-M."

${ }^{177}$ Sciolino et al., "Bombings in Madrid: Reaction," 2.
} 
those who believe that all (forms of) terrorism end up being connected." ${ }^{\prime 17}$ Zapatero also was called to testify in front of the parliamentary commission. During his testimony, Zapatero claimed that all computer records of Aznar and his office between March 11 and March 14 had been wiped. Zapatero accused Aznar of attempting to fool Spaniards into believing ETA was at fault and of "massive deceit." "179 Ultimately, the members of the investigative panel disagreed with Aznar's “absolute proof” of ETA involvement. They concluded that the former government of Aznar "manipulated and twisted" information about the blasts and that ETA "had played no role in the blasts." 180 However, this did not quell the conspiracy theories on the right regarding the blame for the attack.

As evident by the conspiracy theories being perpetuated by the right regarding the attacks, they have had the effect of sowing doubt into the narrative of who perpetrated the attacks. Manganas concluded that the main conspiracy narrative was only to do this, but to also insist that the attack was the sole reason for the defeat of the PP. His description of the main narrative in the conspiracy theory shared many similarities to other out of the realm of possibilities that most conspiracy theories contain:

The conspiracy theory reads something like this: that the March 11 attacks were mounted by remote control by some Spanish political groups with Moroccan and French agents and executed by Basque terrorists and al-Qaeda working side by side with the blessing of the Spanish left and some news media. ${ }^{181}$

With both sides creating narratives of the attack, the duality of Spain has continued to widen and divide Spain.

A 2007 trial which convicted twenty-one out of twenty-eight on charges of terrorism showed that the conspiracy theories had not been disproven well enough for some politicians. Politicians on both sides accused each other of "playing politics with the tragedy" even with the

\footnotetext{
${ }^{178}$ Giles Tremlett, “Aznar Asserts Ties between ETA and Islamists over Madrid Terror Attack," Guardian, Madrid, November 29, 2004, accessed September 4, 2015, http://www.theguardian.com/world/2004/nov/30/spain.gilestremlett.

${ }^{179}$ Giles Tremlett, “Aznar 'Wiped Files on Madrid Bombings'," Guardian, Madrid, December 13, 2004, accessed September 4, 2015, http://www.theguardian.com/world/2004/dec/14/spain.gilestremlett.

${ }^{180}$ Dale Fuchs, “Aznar accused on Madrid bombing," Guardian, Madrid, June 22, 2005, accessed June 22, 2005 , http://www.theguardian.com/world/2005/jun/23/spain.dalefuchs.

${ }^{181}$ Manganas, "Mass-Mediated Social Terror," 13.
} 
judge going out of his way to tell the media and those present at the trial that "there was no evidence to support what has become an enduring conspiracy theory in Spain." 182 The trial's verdict happened to also be pronounced on the same day that another major event in modern Spanish memory politics occurred: the final version of the 2007 Law of Historical Memory was approved by Parliament. ${ }^{183}$ However, both the trial and the law did not completely remove the political controversies over either event.

Considering the trial outcome of Islamist terrorists being responsible for the attack, there have been articles published which refute the evidence to "prove" that the official narrative was false. One such article, published in 2009 , argued that the evidence which confirmed the theory of an Islamist attack "can not [sic] stand up to rigorous analysis" and that "suspicious behavior of certain elements of the police forces clearly indicates the existence of an intent to sabotage the investigation." ${ }^{\prime 184}$ This biased account of the evidence and how the police supposedly tampered with the evidence was enlightening on some of the arguments utilized by conspiracy theorists to explain how the government/police were behind the attacks. Though the article does not explicitly state who was behind the attack, it does place blame of evidence inconsistencies squarely on the shoulders of police who were also to blame for "falsification of testimony." 185

Based particularly on the 11-M trial outcome, the extensive research by Reinares, the claims by the terrorists themselves, and the consensus by most researchers, one must conclude that Islamists conducted the Madrid train attacks and that they were likely connected to Al Qaeda in some fashion. Indeed, an Al Qaeda related group, the Abu Hafs al-Masri Brigade (considered a cell under the Abu Nayaf al-Afghani group) claimed responsibility for the attack. In contrast, the claims by Aznar and the PP that the terrorists were the ETA must be refuted. Why the terrorists attacked Spain is addressed next.

\footnotetext{
${ }^{182}$ Dominic Hughes, "Views from Madrid on bomb verdict," BBC News, Madrid, last modified October 31, 2007, accessed September 4, 2015 , http://newsvote.bbc.co.uk/mpapps/pagetools/print/news.bbc.co.uk/2/hi/europe/7071975.stm.

183 "The Madrid Bomb Trials: Historic Verdicts," The Economist, Madrid, November 1, 2007, accessed September 14, 2014, http://www.economist.com/node/10064645/print.

${ }^{184}$ Mathieu Miquel, "March 11, 2004. The Madrid 3/11 Bombings: Was It Really an Attack by 'Islamic Terrorists'?" The Centre for Research on Globalization, December 6, 2009.

${ }^{185}$ Miquel, "March 11, 2004. The Madrid 3/11 Bombings."
} 


\section{Terrorists' Motivation}

One of the main controversies over the attack is the question of what motivated the terrorists to attack Spain. Some of the major possible reasons which have been cited were the presence of Spanish troops in Iraq, Spain being the "weakest" of the major allies in Iraq, creation of fear, and the desire for the return of Al-Andalus.

Spain, the United Kingdom, and the United States were the three main countries diplomatically driving the allied coalition in Iraq. Of those three, terrorist masterminds determined through analysis that Spain was the weakest and the easiest for targeting and manipulation. ${ }^{186}$ Along with this, the terrorists recognized the instability that could be achieved prior to the upcoming election. They saw the election as a "lever that, if pressed correctly, could help achieve their aims: to destabilize 'the coalition of the willing' and force a big army to abandon Iraq." "187 This coincided with the central Al Qaeda leadership calling for an attack on the West. As Osama bin Laden was quoted as saying in October of 2003, Al Qaeda "reserved the right to respond at the opportune moment and place against all of the countries participating in this unjust war, in particular: Great Britain, Spain, Australia, Poland, Japan, and Italy."188 Spain also had historical significance as part of the master plan for Al Qaeda. Part of the major global plan of Al Qaeda is the re-establishment of the Muslim caliphate of the Middle Ages, which includes Spain itself. ${ }^{189}$

Along with the instability of the Spanish participation in Iraq, historians Patricia Bezunartea, José Manuel López, and Laura Tedesco argued that there were several other reasons for Spain being targeted by terrorists. Not only was Spain considered the weakest of the allies, the country had also been a major staging point for international terrorism due to its proximity to Africa and to the existence of radical Islamic networks which provided logistical support for other attacks. They also argued that the government diversion from the far greater priority and

\footnotetext{
${ }^{186}$ Joshua Levitt, “Analysis: On $10^{\text {th }}$ Anniversary of Madrid Al Qaeda 3-11 Bombing, Analysts Apply Lessons to Fight Terror in Israel," The Algemeiner, March 11, 2014, http://www.algemeiner.com/2014/03/11/analysis-on-10thanniversary-of-madrid-al-qaeda-3-11-bombing-analysts-apply-lessons-to-fight-terror-in-israel/, accessed February $11,2015$.

${ }^{187}$ Levitt, "Analysis."

${ }^{188}$ William E. Baird Jr., "The Madrid Train Bombings: A Decision-Making Model Analysis” (master's thesis, U.S. Army Command and General Staff College, 2009), 48.

189 Baird, "The Madrid Train Bombings," 48.
} 
effort on combating the domestic threat of ETA instead of focusing on international terrorism made them a major target. ${ }^{190}$

Part of the appeal to terrorists who desired a world in which Muslims are able to reclaim their lost medieval territories stemmed from the stories passed down of the Umayyad Kingdom in Iberia known as Al-Andalus. This kingdom was known for its utopian idea of religious tolerance (convivencia) in which Jews, Christians, and Muslims worked together. ${ }^{191}$ This heritage of tolerance made Al-Andalus a powerful force in Europe and Northern Africa from the seventh to the end of the fifteenth century when La Reconquista resulted in the Muslims being driven out of the Iberian Peninsula by Christians. This vision of Muslim Spain as "the ornament of the world," a phrase written by a Saxon writer in the tenth century to describe the capital of Cordoba, was a standard held up by extremists as a potential vision of a resurgence of the Muslim renaissance in the late twentieth century and into the twenty-first. ${ }^{192}$ Al-Andalus was mentioned multiple times by the Al Qaeda leadership as a land that had to be recovered from the infidels who had taken it away. Bin Laden threatened Spain specifically in several of his messages to his followers and to the outside world, especially in a videotape from October 7 , 2001 , in which he directed his focus to an "Al-Andalus for Islamic persons" as an example of the "splendor of the caliphate to be recovered from the infidels." 193

With these varying motivations for the Islamic terrorists who conducted the attack on Madrid, it was easy to see the confusion amid the reports of those who wanted Spain to suffer for fighting in Iraq or those who wanted the return of Muslim rule. Regardless of the personal motivations of the individual terrorists as to why they chose to attack innocent civilians in trains across Madrid, it appears that the overall group motivation for the attack was to punish the Spanish government for siding with the U.S. in the war in Iraq. The bombings may also be seen as part of the overall strategy to attack Western targets. This rationale fits into the evidence of meetings among the leadership of Al Qaeda, the documentation and propaganda police recovered during their investigations, and the analysis conducted by the terrorists into the strengths and

\footnotetext{
190 Bezunartea et. al, "Muslims in Spain and Islamic Religious Radicalism," 13.

${ }^{191}$ Edward Rothstein, "Was the Islam of Old Spain Truly Tolerant?” New York Times, March 13, 2004, accessed September 9, 2014, http://www.nytimes.com/2003/09/27/arts/was-the-islam-of-old-spain-truly-tolerant.html.

${ }_{192}$ María Rosa Menocal, The Ornament of the World: How Muslims, Jews, and Christians Created a Culture of Tolerance in Medieval Spain (New York: Little, Brown, and Company, May, 2002), 12.

${ }^{193}$ Olmeda, "Framing the 3/11 Terrorist Attacks in Madrid and Electoral Accountability," 14.
} 
weaknesses of potential targets; which saw Spain as the best possible target logistically, ideologically, and historically. The evidence pointed to the calls to retake Al-Andalus as more idealistic propaganda than an actual plan.

One area that deserves further study is whether or not North African Islamist groups were involved in the attacks. There is evidence that several members of the terrorist group that conducted the 11-M attacks were members of the Moroccan Islamic Combatant Group (GICM), which is Al Qaeda affiliated. ${ }^{194}$

\section{Aftermath Connection to Duality of Spain}

Incredibly, the controversy over which terrorists were responsible for the 11-M attacks continues to the present time. The continuing controversy has spawned conspiracy theories and has divided Spain. Lisa Abend, reporting five years after 11-M, references opinions about the PP having a difficult time accepting the election loss and the PP viewed the PSOE as having robbed them of the election because of the bombings. She also mentioned that the PSOE believed they won because the PP government was not telling the Spanish people the truth about the attacks and the people realized that the government was lying. ${ }^{195}$ This split between the two parties widened over the next four years of the PSOE government. In a postscript to his article, "Spain Changes Course," Paddy Woodworth wrote on July 5, 2004, that Aznar had just ferociously attacked the Zapatero administration by saying that the change in government was "an unqualified success for the terrorists behind the March 11 bombings" and that the only PSOE policy "consists in the systematic and deliberate destruction of everything that has made Spain a strong and prosperous country." "196 The relationship between the new PSOE government and the PP Opposition began badly and the conspiracy theories were just beginning.

In the first four years of the first Zapatero administration, he greatly changed Spain socially. After he met his promise regarding Spanish troops leaving Iraq, he achieved major legislative victories: 1) full marriage and adoption rights for homosexual couples, 2) fast-track divorces, 3) state control rather than Catholic Church control over religious education in schools,

\footnotetext{
${ }^{194}$ Carlos Echeverría Jesús, “The Current State of the Moroccan Islamic Combatant Group,” CTC Sentinel 2, no. 3 (March 2009): 22-24.

${ }^{195}$ Lisa Abend, "Five Years After the Madrid Bombings," Time, March 11, 2009, accessed July 15, 2014, http://content.time.com/time/printout/0,8816,1884231,00.html.

${ }^{196}$ Woodworth, "Spain Changes Course," 23.
} 
and 4) the Law of Historical Memory to correct the wrongs against the victims of the Spanish Civil War and of the Franco dictatorship. These changes along with the bad feelings from the March 14, 2004, election drove a war between the PSOE and both the PP and the Catholic Church. For example, the Catholic Church issued guidelines for Catholic voters in the 2008 election that "Not all manifestos are equally compatible with the Christian faith and its requirements." Obviously, the guidelines inferred that the PSOE policies were not Christian. All the controversy became very concerning in January 2006 when Lieutenant-General Jose Mena, the head of Spain's army, warned the PSOE government that the army was losing patience with the government over the potential loss of Spanish territory following the granting of greater autonomy to the north-eastern section of Catalonia. Comments were being heard about how some of the political right-wing rhetoric was similar to rhetoric which preceded the Civil War. ${ }^{197}$

Luis García Tojar conducted a study into the conspiracy theories published during the first four years of the Zapatero administration. He said that the confrontation between the PP and the PSOE had produced a wide social breach in Spain because of the "theory of conspiracy," which he defined as "a mixture of lies, false allegations and facts taken out of context aimed at suggesting that the terrorist attack in Madrid was not committed by Islamic fundamentalists but by ETA, and - which is worse - that the socialist government elected on 14 March 2004 for electoral purposes deliberately concealed the evidence that led to ETA terrorists, forcing the police investigation to focus on jihadist groups." Tojar also inferred that if this theory was valid, it meant that the PSOE must have had the support of the police, judges, and foreign intelligence services even before Zapatero formed a government, which was, of course, highly unlikely. ${ }^{198}$ Tojar found that the 11-M conspiracy theory was promulgated by three main, important media: the El Mundo newspaper, the Catholic Church radio station COPE, and the public television channel Telemadrid. He stated that El Mundo was apparently the leader in generating the conspiracy stories and that COPE and Telemadrid followed that lead. He also stated that there was involvement with the PP. He reviewed six major El Mundo published conspiracies and three

\footnotetext{
197 Anthony Ham, "Battle for the soul of Spain," The Age, March 8, 2008.

${ }^{198}$ Luis García Tojar, "11-M: a lesson on greedy journalism," International Review of Sociology - Revue Internationale de Sociologie 20, no. 1 (March 2010): 77-78.
} 
Telemadrid conspiracies broadcast as documentaries. All were clearly fabricated. ${ }^{199}$ One of his conclusions was that the false conspiracies worked. El Mundo and COPE improved the size of their audiences and sales and both placed second in their markets. He indicated that in autumn 2006, a poll found that twenty-three percent of Spaniards and fifty-three percent of PP voters believed that 11-M was not committed exclusively by jihadists. Indeed, the PP had good results in the 2008 election. Another of his conclusions was that the PP appeared to become a neopopulism party. He related how the conspiracy version of 11-M fits into populist movements: "according to it the terrorist attack should make the point of regeneración (regeneration, an old term in Spanish politics) of the people - its characteristic temperance, solidarity and bravery were always highlighted - against immigrants, terrorists (from ETA or Al Qaeda), corrupted politicians and members of the security forces." 200 The regeneración term hearkens back to the period between the Spanish-American War and the Civil War and was one of the intellectual movements seeking to renovate and revitalize Spain. The regeneración movement had an objective and scientific approach to modernization. The movement laid the ideological groundwork for Primo de Rivera's dictatorship and hence for Franco's fascist dictatorship. ${ }^{201}$ Tojar likely used the regeneración term as a way to subtly relate the xenophobia and nationalism of the conspiracy theories to fascism.

In summary, the controversies following 11-M and the 2004 election have widened fractures in a deeply divided Spain. Tremlett may have said it best when he reiterated Aznar and Zapatero testimony to the 11-M parliamentary inquiry. Tremlett stated: "Aznar, in the commission, gave wind to the conspiracy theories. He talked about connections between ETA and Islamists. The 'intellectual authors,' he added mysteriously, were 'not in remote deserts or far-off mountains.' Zapatero, in turn, claimed Aznar had orchestrated 'a massive deceit.' Both theories are now engraved in stone on each side's version of events."202 The identity theme of "two Spains" was valid again.

\footnotetext{
199 Tojar, "11-M: a lesson on greedy journalism," 81-86.

200 Tojar, "11-M: a lesson on greedy journalism," 86-87.

${ }^{201}$ Christopher Britt Arredondo, Quixotism: The Imaginative Denial of Spain's Loss of Empire (Albany: State University of New York, 2005), 39-40.

202 Tremlett, Ghosts of Spain, 251.
} 


\title{
RECOVERY OF MEMORY AND BREAKING OF SILENCE
}

\author{
"White Light" \\ Hundreds of stars fall \\ Over seas of silver, golden oases \\ And cities of reddish clouds of rust
}

Fall my two hundred fragmented bodies,

My three hundred wishes,

My thousands of words fall

Over the children of our children,

Multiplied by the reflection of the millions

Of children of broken glass.

Everything is white light,

I do not hear the sirens

Nor this abrasive odor do I smell.

The red and violet stars fall

Noting the instant at which I am one

And this is you and I, and we were.

A force surrounds us and gathers us,

Proceeds from the silence of the city,

From the beauty of the green mountains

And from the meadows of enameled flowers;

We rise transparent and magical.

Everything is white light.

Julia Barella, "Luz Blanca [White Light],” $2004^{203}$

${ }^{203}$ Julia Barella, "Luz Blanca” in Madrid, Once de Marzo: Poemas para el Recuerdo, ed. Eduardo Jordá and José Mateos (Valencia: Pre-Textos, 2004), 24. Poem translated to English from Spanish by the author. 
In the poem "White Light," Julia Barella described the horrible events which transpired March 11 of 2004 or 11-M as known in Spain. This poem was part of an anthology of memory poetry created in the immediate aftermath of the train bombings. The day after 11-M, the Madrid bookstore Rafael Alberti asked poets throughout Spain to write poems as testimony to the attacks, which could be placed in the windows of the bookstore to pay tribute to the victims. The response was substantial and a few days later, the bookstore commissioned the anthology to give voice to the silence of the dead. ${ }^{204}$ Compared to the silencing of memory following the Spanish Civil War, the outpouring of voices following 11-M was a loud, angry scream.

Furthermore, Spain acted quickly to construct a memorial to the victims of 11-M. An inspiring eleven-meter tall glass tower at the Atocha train station was opened on the third anniversary of $11-\mathrm{M}^{205}$ In contrast to the lack of silence and quick recognition of $11-\mathrm{M}$ victims, this section examines the protracted recovery of memory and the breaking of silence from the Spanish Civil War and how both were impacted by the aftermath of the 11-M attacks. The section begins with a short overview of the Civil War.

\section{Civil War Overview}

The 1920s saw the rise and fall of a dictatorship in Spain under the direction of Miguel Primo de Rivera, who was the leader of Spain from 1923-1930. After his removal and the popular unrest of those who did not want to see the Bourbon King returned to power, democratic elections were held and, in 1931, the Spanish Second Republic was born. This republic was, however, relatively short-lived as it was ended by the Spanish Civil War, which was another example of the Spanish political tragedy and was under assault from many directions by supporters and detractors. ${ }^{206}$ Following elections in 1936 in which the left won, the defeated rightists banded together with the military to force a coup of the government. These rightists, who were led by the monarchy-favoring Carlists and the fascist Falange party, had combined forces with several Spanish military generals (later led by Francisco Franco) who broke their oaths to the Republic when they launched a coup from Spanish-held Moroccan territory in July

\footnotetext{
${ }^{204}$ Eduardo Jordá and José Mateos, Madrid, Once de Marzo: Poemas para el Recuerdo, (Valencia: Pre-Textos, 2004), 11.

205 “Madrid Memorial for Train Victims," BBC News, Published March 11, 2007, accessed January 31, 2015, http://newsvote.bbc.co.uk/mpapps/pagetools/print/news.bbc.co.uk/2/hi/europe/6439825.stm.

${ }^{206}$ Tremlett, Ghosts of Spain, 30.
} 
1936 that would see the right returned to power. ${ }^{207}$ This attack on the government signaled the climax of the political and societal class conflicts which had divided Spain following the creation of the Republic. However, the short coup turned into a brutal three-year civil war which led to the deaths of over 800,000 people and more than 440,000 displaced persons. ${ }^{208}$

The Spanish Civil War saw unprecedented atrocities committed by both sides against the enemy and civilians which were largely ignored outside the Iberian Peninsula due to the greater atrocities which occurred during the Second World War. Both the Nationalists and Republicans committed mass killings of prisoners and civilians during the fighting, including the killings of major cultural and political figures such as founder of the Falange, Jose Antonio Primo de Rivera (son of the former dictator), and the poet Federico Garcia Lorca. The repression the Nationalists committed against Republicans or sympathizers was such that leaders and public figures were executed in order to completely remove the old power structure and society, as well as the systems of freedom that they defended from the outset. One Nationalist general was quoted as saying, in 1936, "Spain cannot be reconstructed until the entire political rabble is swept away." "209 This Nationalist violence continued throughout the war. The Republican violence peaked in 1936 but declined sharply as the war went on. A few of the main focuses of Republican violence were the clergy and Nationalist forces who were captured. The Catholic Church did not attempt to reduce the violence, but instead blessed it and fully supported the Nationalist forces. ${ }^{210}$ In 1939, Madrid fell to the Nationalists and those who supported the Republicans either fled the country into exile or remained in Spain hoping for the day that democracy could return. That day would not come for over three and a half decades.

\section{Amnesty and Silence}

The immediate years following the end of the war saw violence committed against suspected Republicans, though it paled in comparison to what the rest of Europe faced during the Second World War. Most notably, a law was passed after the war ended which provided amnesty to those who committed a slew of crimes "against the Constitution" as long as they

\footnotetext{
${ }^{207}$ Julián Casanova, "History and memory: a new social dimension," International Journal of Iberian Studies 21, no. 3 (2008): 188.

${ }^{208}$ Laia Balcells, "The Consequences of Victimization on Political Identities: Evidence from Spain," Journal of Politics \& Society 40, no. 3 (2012): 316.

${ }^{209}$ Casanova, "History and memory," 191.

${ }^{210}$ Casanova, "History and memory," 194; Ibid., 191.
} 
could prove that they ideologically agreed with the Franco regime. ${ }^{211}$ Spain, though officially a neutral party, sent aid and troops to Nazi Germany and received food and oil from the U.K. and the U.S. Domestically, the victorious Nationalists continued a campaign of terror over the defeated Republicans which resulted in at least 50,000 executions. ${ }^{212}$ Direct violence "lasted several years after the war in the form of executions that had a protolegal nature" and less violent ways of oppression, which had been underway during the war, continued into the postwar period. For example, people were tortured, displaced, imprisoned, or simply sacked from their jobs because they did not side with the Nationalists or subscribe to Francoist ideology. ${ }^{213}$ The cultural white-washing of the Republicans and their achievements had begun. The majority of those killed had somehow benefitted, or were accused of having benefitted, under the system of the Republic. ${ }^{214}$

The Nationalists were all heroes in Franco's "revived" Spain which featured iconography and allusions to the great Spanish Empire of the past. The victory of the Nationalists was endlessly commemorated with those who died had "fallen in the service of God and the Fatherland" with the defeated Republicans suppressed in the background. Families of those who fell fighting for the Republican forces during the war were terrified to the point that most would not even lay claim to the bodies of their relatives or loved ones during the postwar period. ${ }^{215}$ The period of purification of society coincided with the economic policy of autarky which the Franco regime followed, which effectively cut Spain off from the rest of Europe as a way to treat a "sick" Spain by placing it in "quarantine."216 The purpose of this self-containment of Spain was to ensure that the crusade to liberate Spain from a "foreign, atheistic and un-Spanish yoke" could be completed without outside interference. ${ }^{217}$ Also during this period, anti-government forces formed and struck out with terrorist attacks and assassinations as a way to demand greater regional autonomy (as in the Basque region with ETA) or to attempt to overthrow the government. However, the fate of both Fascist Italy and Nazi Germany was not shared by Spain and Franco endured past V-E Day in 1945.

\footnotetext{
211 Aguilar, Memory and Amnesia, 76n62.

212 Casanova, "History and memory," 198.

${ }^{213}$ Balcells, "The Consequences of Victimization on Political Identities," 316.

${ }^{214}$ Graham, "The Spanish Civil War, 1936-2003," 314.

215 Casanova, "History and memory," 189.

${ }^{216}$ Michael Richards, A Time of Silence: Civil War and the Culture of Repression in Franco's Spain, 1936-1945 (Cambridge: Cambridge University Press, 1998), 174.

${ }^{217}$ Vincent, "Memory and oblivion since the Spanish Civil War," 56.
} 
The 1950s-1960s saw a renewed effort by Spain to attempt to regain international support, as the immediate postwar years saw relative isolation of Spain by the victorious democratic nations in the newly-formed U.N. But as the United States became more concerned about expansion of Soviet communism, the Iberian Peninsula was recognized as being strategically important. Following a U.N. resolution lifting the boycott of Spain, the U.S. resumed diplomatic relations with Spain in 1951. Then in 1953, the Pact of Madrid was signed, which ended Spain's neutrality and established a mutual defense pact with the U.S., the construction of U.S. military bases, and U.S. economic and military aid. Subsequently in 1955, Spain was admitted to the U.N. Although Spain became more open to the world as isolation ended, Franco maintained tight control over the country except for loosening control over the economy in the late 1950s. The government narrative about the Civil War did not change.

The nature of the commemoration of the Spanish Civil War also did not change during this period. This was highlighted with the completion of the Valley of the Fallen monument in 1959, which was built to commemorate the war and to honor the victimhood of Primo de Rivera in 1936 and of those others who fought for the Nationalists. The monument was constructed over the course of eighteen years, of which the majority of the excavation and construction was completed by political prisoners, and remains the biggest war memorial in the world (as well as the one with the most religious iconography). ${ }^{218}$ The executions of political prisoners still occurred in the 1950s and early 1960s. The last person executed for Civil War crimes was killed in 1963, over twenty years after the conclusion of the war and the prosecution of all crimes committed during the war was ended by a law passed by Franco in $1969 .^{219}$ Thus, the AntiMarxist war (which Franco preached was the purpose of the Civil War) continued well past the cessation of hostilities. This continuation was in order to silence the opposition's memory of the events and then perpetuate the Nationalist victory. Ultimately, Spain was able to recover from a disastrous postwar economy of autarky into a relatively-thriving economy in the 1960s to early 1970s thanks to a booming tourist sector. This booming tourist sector was hampered by increased emigration from the country as Spaniards sought work in other countries. ${ }^{220}$ The 1970s saw a period of stagnation but also of hope as changes and transitions changed Spain.

\footnotetext{
218 Jeremy Treglown, “A A heartless craft': Spain's history wars,” The Dublin Review no. 28 (Autumn 2007 ): 8.

219 Tremlett, Ghosts of Spain, 34; Viejo-Rose, Reconstructing Spain, 152.

${ }^{220}$ Viejo-Rose, Reconstructing Spain, 151.
} 
The period of transition actually started during the final years of Franco's life as protests erupted across the country in the 1970s. Much of the impact of these protests was lost in the later events of the transitional period of the mid-1970s; however, they were influential in those later changes. The mass protests themselves were organized by ordinary citizens who risked torture and imprisonment to help create the conditions which would lead to the downfall of the dictatorship and the rise of democracy. ${ }^{221}$ These protests were helped by the changes which had opened up Spain in the 1950s and 1960s. The accelerated modernization and the progress towards economic assimilation into Europe helped to undermine the Spaniards support for authoritarianism and autarky. ${ }^{222}$ The ironic aspect of these protests was that the changes that were introduced later on were consolidated by both the left and the right in order to avoid later problems that could end democracy. Some of these problems included regional languages and customs, as well as alternative nationalisms, which had caused headaches for Franco and state policy makers for the regime during the dictatorship. ${ }^{223}$ Therefore, the dictatorship was "eased out of existence" and the past was not reconciled in order to attempt to sweep the period of the 1930s-mid 1970s under the rug. ${ }^{224}$ This process for transition was also aided by the Spanish King, Juan Carlos.

King Juan Carlos was the son of the former Spanish King, who was exiled in 1931, and was picked by Franco to return to the Spanish throne as he had not interfered with the dictator's plans. The monarch's presence also fit into Franco's plans as he saw the King as a person to take over after his own death to ensure the continuation and survival of the dictatorship. ${ }^{225}$ However, the protests and the pressure from multiple groups caused the advisers to the monarch to see that real changes had to occur to ensure the survival of the monarchy post-Franco. ${ }^{226}$ As such, the transitional period was not hampered by the monarchy and (ultimately) aided by it. Even with

\footnotetext{
${ }^{221}$ Sebastian Balfour, "Introduction: Spain since the transition to democracy: an overview," in The Politics of Contemporary Spain, ed. Sebastian Balfour (New York: Routledge, 2005), 4.

${ }^{222}$ Balfour, "Spain since the transition to democracy," 4.

${ }^{223}$ Xosé-Manoel Núñez Seixas, "From National-Catholic nostalgia to constitutional patriotism: conservative Spanish nationalism since the early 1990s," in The Politics of Contemporary Spain, ed. Sebastian Balfour (New York:

Routledge, 2005), 138.

${ }^{224}$ Balfour, "Spain since the transition to democracy," 4.

${ }^{225}$ Paul Preston, "The monarchy of Juan Carlos: From dictator's dreams to democratic realities," in The Politics of Contemporary Spain, ed. Sebastian Balfour (New York: Routledge, 2005), 27.

${ }^{226}$ Preston, "The monarchy of Juan Carlos," 27.
} 
this help and support of the monarchy in the gradual shift away from authoritarian rule, regional differences still crept into the limelight and caused unrest in the last years of the Franco regime.

The gradual opening of Spain and discussion of potential reforms briefly halted in 1973 as hardline repression and censorship made a return. This was due to the assassination of the Spanish Prime Minister (and potential successor to Franco) Admiral Carrero Blanco by ETA. ${ }^{227}$ The harsher censorship made a small dent in the release of films which dealt with themes and circumstances which resembled Spain during the dictatorship, however the fact that these movies were allowed to be released in the first place demonstrated the loosening of control by the Franco regime in its final years and its diminished aversion to democracy. This does not mean that supporters of the regime were in total agreement with the changes that occurred, as demonstrated by a younger Aznar who was a supporter of the Falange as early as sixteen-years-old. Later articles he published during the late 1970s indicated his respect for dictatorship, aversion to democracy, and hostility to the term "nationalism." Ironically, he would later state his support for the 1978 Constitution as the standard for Spanish democracy. ${ }^{228}$ However, the regime was forced to change leaders when Franco died November 20, 1975.

Following the death of the planned successor Blanco, Franco appointed Carlos Arias Navarro to be the leader in Spain and the one to takeover full responsibilities following the dictator's death. It was Navarro who had ordered the re-emerged repression following Blanco's death in a time of turmoil and divisions in where the regime was heading. ${ }^{229}$ Once Franco died in late 1975, Navarro was in control of the government. Navarro and his staff also were charged with making sure the regime could continue on without Franco. There was concern among political elites that Franco's death would spell the end of their legitimacy. ${ }^{230}$ Juan Carlos also had a place in government and, ultimately, a say in the direction of the future. He broke with the past and the Franco regime when he betrayed the deceased dictator's wishes and dismissed the Navarro government in July 1976 and appointed his own leader, a younger Francoist insider by the name of Adolfo Suárez, to lead the transition to democracy. Suárez's appointment led to the 1976 Law of Political Reform which essentially voted the Franco regime out of office. It also

\footnotetext{
${ }^{227}$ Labanyi, "Memory and Modernity in Democratic Spain," 97.

${ }^{228}$ Woodworth, "Spain Changes Course," 9.

${ }^{229}$ O.G. Encarnación, Spanish Politics: Democracy after Dictatorship (Malden: Polity Press, 2008$), 33$.

${ }^{230}$ Viejo-Rose, Reconstructing Spain, 152.
} 
led to the dissolution of the Francoist parliament and legalized political parties, along with other liberties enjoyed in democratic countries. ${ }^{231}$ However, these changes still differed from all other democratic countries and other transitional governments born out of authoritarianism. They differed because many of the main institutions and people behind these changes had been part of the old guard of Francoism and had not been ousted or removed as in many other examples of revolutionary governments. ${ }^{232}$ As part of his commitment to building consensus, Suárez reached out to the Communist opposition and both sides agreed to negotiations to allow free elections. Other liberalizations occurred, such as universal suffrage and a bicameral system of representation, in the months that followed. The first elections since the 1936 election (which led to the rebellion) were held on June $15,1977 .{ }^{233}$

The elections led to an unsurprising result: the center-right party founded by Suárez, the Unión de Centro Democrático (UCD), won thirty-four percent of the popular vote and 118 parliamentary seats. Under the UCD, the bulk of the transition occurred. On October 27, 1977, Prime Minister Suárez and leaders of the majority of political parties (minus those on the farright and far-left fringes) signed what became known as the Moncloa pacts which announced the commitment of the political parties to allow a collaborative process to policy making. ${ }^{234}$ This coincided with the deliberations of parliament on the articles that would go into the Constitution. These deliberations resulted in the negotiation of the first twenty-five articles by the UCD, which were opposed by the PSOE. This opposition led to a change in the negotiations to a joint operation between the PSOE and the UCD. ${ }^{235}$ The Constitution was later passed in 1978 and consequently the bulk of the transition from a dictatorship to a constitutional monarchy occurred under the new constitution.

To allow the two major sides to cooperate, the government and the major political parties decided that the best way was to forget the past grievances. This was accomplished in an unwritten pact of silence (pacto de silencio) and a law: the 1977 Amnesty Law. This law essentially provided the legal basis that "allowed the country 'to pretend that it had forgotten the

\footnotetext{
${ }^{231}$ Encarnación, Spanish Politics, 33-35.

232 Viejo-Rose, Reconstructing Spain, 153.

${ }^{233}$ Encarnación, Spanish Politics, 35-37.

${ }^{234}$ Ibid., 37.

235 Jonathan Hopkin, "From consensus to competition: the changing nature of democracy in the Spanish transition," in The Politics of Contemporary Spain, ed. Sebastian Balfour (New York: Routledge, 2005), 16.
} 
past" "and enabled the creation of a new political order that was built on mutual respect and tolerance. ${ }^{236}$ However, this did not help the families who had lost loved ones during the Civil War and had not been able to come to terms with that loss during the dictatorship. The restitution for the crimes was indefinitely delayed and would not become a political issue until over two decades following the constitution. If the silencing of post-Civil War memories were as a dam (the pact of silence) stopping the flow of water (Republican memories), the transition period only patched the small cracks that were appearing from the weakening of the authoritarian regime and the dam kept the outpouring of memories from occurring. This should not understate the importance of the Law of Amnesty, as it provided the basis for later memory recovery once there was sufficient distancing from the dictatorship. The law did include some of the most basic restitutions: such as purged army officers being reinstated, disabled veterans receiving pensions, and compensation for those jailed for more than three years. ${ }^{237}$ Not only was there an attempt at a basic reconciliation with Republicans who had suffered during the war and postwar period, there was also an attempt to reconcile with those were in exile and those regions who had been alienated during the years of the dictatorship.

Preliminary steps were taken to recover Spanish heritage by the public recovery and reintegration of those Spaniards who had been exiled after the war and the decision for the creation of autonomous regions through the Constitution. ${ }^{238}$ This also included attempts to rectify past grievances to a small extent such as the bombing of Guernica during the Civil War. Events began to be organized to commemorate the bombings and their victims started as early as April $23^{\text {rd }}, 1977$, and represented the beginning of atonement for some of the crimes committed by the Franco regime and the Nationalists. ${ }^{239}$ Unfortunately, these steps were not fully implemented and have remained a sticking point in Spanish politics as silence and amnesia pervaded. Part of this was due to the breakdown of cooperation between the two main sides of the left and the right due to mutual distrust (not just between the parties, but also between the parties and the people). ${ }^{240}$ Another part was due to the strained relations between the UCD and Suárez after the elections of 1979, as leaders within the party began to lower their support for

\footnotetext{
${ }^{236}$ Vincent, "Memory and oblivion since the Spanish Civil War," 49; Boyd, "The Politics of History and Memory," 135.

${ }^{237}$ Vincent, "Memory and oblivion since the Spanish Civil War," 63.

${ }^{238}$ Viejo-Rose, Reconstructing Spain, 154.

239 Aguilar, Memory and Amnesia, 201.

${ }^{240}$ Ibid., 230.
} 
Suárez as they saw him as trying to build too much consensus. However, Suárez's motivation for compromise paved the way from dictatorship to democracy.

The reason that it was important for both sides to cooperate was the mutual fear that any major disputes between the main parties could lead to a repeat of 1936 . This fear resulted in political elites compromising on "contentious issues rather than risk confrontation during the transition period." ${ }^{241}$ Many of the meetings of the new government, even prior to the first elections, had violence to contend with as the breakdown of the authoritarian rule led to explosions of attacks by the left and the right. 1976 was a particularly violent year as ETA attacked governmental targets (including the murder of the head of a provincial council) and a right-wing revolutionary organization kidnapped the president of the council of state and the president of the superior council of military justice. ${ }^{242}$ Thus, the transition period consisted of both moderation and violent extremism which in turn affected the process of the overall transition. The fear of a new Civil War almost became all too real when early in 1981, a group of officers within the military attempted a coup of the government.

On February $23^{\text {rd }}, 1981$, a group of officers led by Civil Guard Lieutenant Colonel Antonio Tejero stormed parliament and held the members at gunpoint. ${ }^{243}$ This coup attempt sparked fears of the outbreak of another civil war and the reconciliation process was halted. This included efforts to pay homage to Republican war dead and exhumation of graves, which would not be reconciled until at least two decades later. ${ }^{244}$ Ultimately, the coup failed when the rest of the military did not join in the attempt to overthrow the government. This was due to the mass outpouring of support for democracy by Spaniards, who demonstrated in the streets during the day of the attempt, and the subsequent refusal of Juan Carlos (head of the military) to allow the continuation of the coup. ${ }^{245}$ The damage, though, had already been done. The reconciliation that had been pushed during the late 1970s up until early 1981 was halted and a return to consensus was pushed by both sides. Both the Socialists and the UCD temporarily restored consensus

\footnotetext{
${ }^{241}$ Hopkin, "From consensus to competition," 16.

${ }^{242}$ Nancy Bermeo, "Myths of Moderation: Confrontation and Conflict during Democratic Transitions," Journal of Comparative Politics 29, no. 3 (April 2007): 309.

${ }^{243}$ Tremlett, Ghosts of Spain, 35; Viejo-Rose, Reconstructing Spain, 153.

${ }^{244}$ Blakeley, "Consequences of Truth and Reconciliation," 51.

245 Blakeley, "Consequences of Truth and Reconciliation," 52; Preston, “The monarchy of Juan Carlos,” 27.
} 
following the coup, however that consensus was short-lived as the UCD began to have internal structural problems and later lost the elections of $1982 .^{246}$

In 1982, the infighting within the UCD cost them the election and the Socialists became the ruling party. Thus, the first left-wing party was in power since before the Civil War. However, the silence which had resulted from the transition period persisted as none of the political leaders in Spain wanted to shake-up the status quo. The Socialists focused their efforts on celebrating older events as a way to look at Spanish history from before the twentieth century. For example, two of the major events that were celebrated were the discovery of America (the quincentenary in 1992) and the death of the Enlightenment king, Charles III (the bicentenary in 1988). ${ }^{247}$ These events were an attempt to get people to forget about the dictatorship and to celebrate the glorious past of Spain. However, this was the same attempt the Franco regime tried and the Spanish people did not feel the same way about the need to completely silence the period of the dictatorship and Civil War. Even as early as the 1970s, the Civil War was a popular topic of discussion within academia and through popular culture (notably films). ${ }^{248}$ However, most Spaniards still agreed that the avoidance of official reckoning of the past was the correct thing to do. $^{249}$ Advisors within the government also agreed that it was the correct thing to do. The leader of the PSOE, Felipe González, was even cautioned by a former general to leave the subject of the Civil War alone in order to "not provoke the ire of the army."250 Nonetheless, the 1990s saw an increase in the academic discussion of the war, which grew to heated exchanges at the end of the Socialist period.

\section{$\underline{\text { Breaking of Silence }}$}

As historians began to conduct more research into the Civil War and the Spanish Second Republic in the 1990s, opinions from the transition were called into question. The research allowed the Republic past of Spain to lose its' connection to dysfunctionality and Marxism and became more respectable and palatable versus the Franco regime conceptualization. ${ }^{251}$ This also reflected a shift in victimhood for each side. The shift occurred as archival research pointed to a

\footnotetext{
${ }^{246}$ Hopkin, "Democracy in the Spanish transition," 19.

${ }^{247}$ Núñez Seixas, "Conservative Spanish nationalism since the early 1990s,” 124.

${ }^{248}$ Vincent, "Memory and oblivion since the Spanish Civil War," 49.

${ }^{249}$ Boyd, "The Politics of History and Memory," 135.

${ }^{250}$ Tremlett, Ghosts of Spain, 35.

${ }^{251}$ Boyd, "The Politics of History and Memory," 136.
} 
greater amount of violence/deaths committed by Nationalists against Republicans than the other way around; which was the official narrative during the postwar period. ${ }^{252}$ The reshaping of the past in order to open the discussion of what had happened during the Civil War caused the later collective memory boom of the late 1990s and early 2000s as it changed the history, memory, and oblivion of the war and the dictatorship. ${ }^{253}$ The boom would occur under the rule of the main right-wing party in Spain, PP, which came about following corruption scandals within the ruling PSOE in the mid-1990s.

Following their defeat in 1982, the UCD lost most of its relevancy. In fact, they were not the main opposition to the PSOE during the 1980s and first half of the 1990s. That job went to the further-right group, the CP (Coalición Popular). The CP eventually was taken over by Aznar, who rebranded the CP as the PP in $1989 .{ }^{254}$ Aznar's desire to lead Spain was helped by the corruption scandals that sullied the image of the PSOE as well as a continued illegal war the party fought against ETA in the late 1980s, but the PSOE remained in power until 1996. Aznar's own hatred of ETA stemmed from an attempt on his life in 1995 when a bomb almost killed him. ${ }^{255}$ His popularity continued to increase and in March of 1996, the PP won the election but was unable to gain an absolute majority. As a result, Aznar cautioned his party to tread softly in the first term and make more rightist policies in subsequent terms. ${ }^{256}$ Regardless of policies, the victory for the PP spelled the first time that a right-wing party had won an election within Spain.

During the first term of Aznar as Prime Minister, the right-wing policies that were enacted were small and gradual to avoid fears of a major shift to the right. However, the theme of the "two Spains" was still alive and well during this period. The PSOE opposition began to use the Civil War as an electoral weapon against the PP, which became most apparent in 1999 as the next election was nearing. ${ }^{257}$ Along with this, the PP created a committee in 1997 aimed at reforming history education in Spain. The Plan for Improving the Humanities, as the initiative which created the committee was called, led to the development of a syllabus which "restored the balance between premodern and modern history" and focused on the "unitary character of the

\footnotetext{
252 Boyd, "The Politics of History and Memory," 137.

${ }^{253}$ Casanova, "History and memory," 190.

${ }^{254}$ Woodworth, "Spain Changes Course," 9.

255 Ibid., 10.

${ }^{256}$ Ibid., 11.

${ }^{257}$ Núñez Seixas, “Conservative Spanish nationalism since the early 1990s,” 124.
} 
historical trajectory of Spain." ${ }^{, 258}$ This angered many regionalist groups in Catalonia and the Basque Country as they saw the syllabus as an attempt to eliminate the autonomous regions and their own histories. Large numbers of essays and editorials were published in 1997 speaking for or against the educational reform. This started the "history wars" which signified the beginning of major debates in politics, academia, and the general public over the Civil War and Franco dictatorship. The education reform was dropped by the end of 1997 as only the PP supported it, but it would make an appearance again in the PP's second term of 2000-2004. ${ }^{259}$ The need to reconcile the past came to a head in 1998 when Spain made international news.

On October 16, 1998, General Augusto Pinochet of Chile was arrested in London on charges brought by Spain for the disappearances of thirty-five Spanish nationals in Chile during his dictatorship. The charges were made by Judge Baltasar Garzón, who argued that the forced disappearances were an on-going crime not just against the victims but also against the people who had been obstructed by the government during their search for the disappeared. ${ }^{260}$ This was ironic as it showed that Spain was willing to prosecute crimes against humanity in other countries (involving her citizens) yet was unwilling to prosecute crimes committed at home. Therefore, this arrest led to more calls for the recovery of collective memory and served as a precursor for what would happen in the PP's second term.

In 2000, the PP was elected to a second term with a majority in Parliament. With the majority, their policies became more and more conservative during this term as they sought to consolidate their power. But in a surprising move, the PP did explicitly condemn the 1936 coup and the Francoist regime in a 2002 parliamentary bill. ${ }^{261}$ At the same time, they continued the fight against regionalism by focusing on collective national ceremonies and symbols. The PP promoted flying the Spanish flag in public, the playing of the national anthem, and displaying the coat of arms. This also included the proclamation of the need to support collective events and sports to "strengthen the cohesion of different social strata." 262 Though, the only way to strengthen this cohesion would be to forget about the Civil War and the Franco regime. However for all intents and purposes, this was not done during the period of PP rule as they

\footnotetext{
${ }^{258}$ Boyd, "The Politics of History and Memory," 140.

${ }^{259}$ Ibid., 141.

${ }^{260}$ Blakeley, "Consequences of Truth and Reconciliation," 45-46.

${ }^{261}$ Núñez Seixas, "Conservative Spanish nationalism since the early 1990s,” 124.

262 Ibid., 135.
} 
alluded to the use of the "glorious past" that was a return to the harping during the period of the dictatorship. ${ }^{263}$ Education also began to focus more on traditionalist views in an echo of the Franco period.

In 2003, a more radical set of reforms created by a new Minister of Education was passed through parliament (as the PP had the majority). These reforms were "designed to shape the values of new generations of Spaniards along traditionalist lines." 264 These traditionalist values included the return of religion as a compulsory subject. However, this went against the 1978 Constitution. In the Constitution, it explicitly stated that there was to be a separation of church and state. ${ }^{265}$ Thus, the PP was more interested in traditional values than compromise and following the Constitution. At the same time as this was happening, collective memory became more and more of a popular discussion as steps were taken to recover lost Civil War memory and bodies.

Starting in the late 1990s, the recovery of collective memory became more of an interest for the general public. A grassroots campaign to create a public memory of the Civil War culminated in 2000 with the creation of the Association for the Recovery of Historical Memory (ARMH). ${ }^{266}$ The work of this association has often been seen as the beginning of the breaking of the pact of silence and, at least in the general population of Spain, a willingness to address the issues brought about by the Civil War and the Franco dictatorship. This also extended to the desire for restitution for the victims and their families, the honoring of the dead, and the acknowledgement of the extra-legal violence that plagued both the Republican forces and the Nationalist/Francoist forces during and after the war. ${ }^{267}$ The public view of restitution and recognition (as well as confronting) of the past was more prevalent in younger generations. For example, a slight majority of Spaniards in the early 2000s were still afraid of a recurrence of political violence as a result of confronting the past. However, by a significant margin, young Spaniards were least likely to hold this same fear as they had not been alive during the Civil War

\footnotetext{
${ }^{263}$ Núñez Seixas, "Conservative Spanish nationalism since the early 1990s,” 135.

${ }^{264}$ Sebastian Balfour, "The Reinvention of Spanish conservatism: The Popular Party since 1989," in The Politics of Contemporary Spain, ed. Sebastian Balfour (New York: Routledge, 2005), 158.

265 Balfour, "The Popular Party since 1989," 158.

${ }^{266}$ Vincent, "Memory and oblivion since the Spanish Civil War," 64.

${ }^{267}$ Ibid., 64-65.
} 
or the dictatorship. ${ }^{268}$ The cracks in the dam of silence were getting wider. The 2002 condemnation of the 1936 coup signaled a change from a forward-looking plan based in consensus to establish democracy (as in the original pacts of the 1970s) to a backward-looking plan based in dissent to consolidate democracy and as a way to renegotiate what had happened during the transition. The two plans resulted in two separate outcomes: political conciliation in the case of the 1970s and social reconciliation in the case of the 2000s. ${ }^{269}$ These plans were also thrown into disarray by dramatic events: the 1970s reconciliation by the 1981 coup attempt and the 2000s reconciliation by terrorist attacks.

Given Aznar's hatred of ETA, it was understandable to see why he would focus so much effort on antiterrorism. The international scene for terrorism, which exploded after 9/11, allowed Aznar to intensify the antiterrorism campaign. This also benefitted PP strategy to avoid any negotiations with the Basques, which would undermine the push toward an integrated nationalism in Spain. ${ }^{270}$ Even the banning of a political party, an event unknown in democratic countries, was not the subject of international condemnation when the PP banned the Basque party known as Batasuna in 2002. This undisguised attack on regionalism and democracy in Spain led to more radicalization among those wanting more autonomy and further division between regional interests and the main government, something the PP claimed to be trying to work for. ${ }^{271}$ Negative PP emotions were extended to the ARMH. The ARMH was seen as creating more division and shining light on the period the PP wanted to put to bed. ${ }^{272}$ The explosion of collective memory and the antiterrorism campaign would become interconnected following the 11-M bombing in 2004.

\section{$\underline{11-\mathrm{M} \text { Aftermath }}$}

Following the 11-M attack, responses by the Spanish public were quite distinct from those which had come from the transition period or the postwar period. Those older periods saw the general public respond with fear. The aftermath of 11-M saw the general population respond with anger, the polar opposite of what the past had seen. Along with anger, the Spanish people

\footnotetext{
${ }^{268}$ Boyd, "The Politics of History and Memory," 143-144.

${ }^{269}$ Blakeley, "Consequences of Truth and Reconciliation," 53-54.

${ }^{270}$ Woodworth, "Spain Changes Course," 12.

${ }^{271}$ Ibid., 13.

272 Ibid., 14.
} 
voted the PP out of office and an intensification of the breaking of silence (a process started in the 1990s) occurred. The mobilization of people to demonstrate was also faster and more pronounced as technology had improved significantly since the 1970s. The protestors were able to organize in greater numbers in more cities and were able to get their anger across through the polls three days after the attack. ${ }^{273}$ This anger plus the unpopularity of the policies which had been implemented by the PP (especially in their second term) led to the victory of the PSOE. The regions that saw the most dramatic change in support from PP to PSOE were the autonomous regions, such as the Basque Country and Catalonia, which had been negatively affected by PP policies. ${ }^{274}$ The change in government also signaled a change in major support and sphere of influence. The Aznar government was focused on increasing Spain's power and world standing by allying with the United States, the United Kingdom, and Italy. The Zapatero government was focused more on strengthening the European Union and ties with the member nations as well as restoring the respect and confidence of European partners. ${ }^{275}$ As the Socialist government changed spheres of influence, they also changed the official discussion on collective memory with initiatives to restore the Second Republic memory as well as continued efforts to improve on the 1977 Amnesty Law.

The memory boom intensified under the Socialist government as commissions were created and laws were passed to reconcile the two competing Civil War collective memories. However, this competing collective memory was not something that could be easily reconciled and was a factor that led to further ideological divides within Spain. ${ }^{276}$ One of the major controversies which resulted from the memory boom was that revolving around the Spanish Second Republic. The PP had engaged in historical revisionism in the late 1990s and early 2000s to show that the Franco dictatorship was "a necessary period of recuperation from the chaotic interlude of the republic and civil war" and depicted the Second Republic as a radical period in which a gradual progression of liberalism (starting in the late nineteenth century) to democracy was interrupted by the republic. ${ }^{277}$ In contrast, the PSOE worked to rehabilitate the Second Republic. This was partly done by describing it as part of a historical continuation which

\footnotetext{
273 Balfour, "Spain since the transition to democracy," 3.

274 Balfour, "The Popular Party since 1989," 163.

${ }^{275}$ Mary Farrell, "Spain in the new European Union: in search of a new role and identity," in The Politics of Contemporary Spain, edited by Sebastian Balfour (New York: Routledge, 2005), 229.

${ }^{276}$ Boyd, "The Politics of History and Memory," 144.

${ }^{277}$ Ibid., 141.
} 
led to the stable democracy following the 1978 Constitution. ${ }^{278}$ The work to rehabilitate the past and to patch old wounds was exemplified in the 2007 Law of Historical Memory, which was a bipartisan supported law pushed by the PSOE to attempt to deal with the collective memory once and for all.

On December 10, 2007, the Spanish parliament continued the opening of discussion on injustice and atrocities committed during the whole Civil War period by approval of the Senate for the passage of the Law of Historical Memory. This law included the classification of sentences carried out by the Franco regime as "illegitimate" as well as instruction for national authorities to help in the location and exhumation of bodies from Nationalist and dictatorship mass graves. ${ }^{279}$ This greater effort to address the memories and silences of the past further intensified the breaking of silence. To reuse the dam analogy, the cracks were widening to the point that small rivers of water were pouring out into the general collective Spanish memory. However, the dam of silence was not completely broken with this law and exterior events also led to erosion. Silences are broken down through the passage of time, groups are able to come to terms with collective loss or disaster, and the needs of the group change. ${ }^{280}$ The Law of Historical Memory also extended the coverage of reparations which had been initially approved in the 1977 Law of Amnesty. What rights had been given to military officers, soldiers of the Republican forces, and long-term prisoners (more than 3 years) under the 1977 law were broadened to include orphans, injured civilians, and those who served short-term incarcerations during the Civil War and the Franco regime. ${ }^{281}$ Even with these concessions, the refusal of the PP to allow the majority of the original plan for the Law of Historical Memory (including the refusal to nullify all sentences carried out by the Franco dictatorship) to be carried out showed the deepening ideological rift emerging in Spain. The law also explicitly refused to define or impose a collective history on the Spanish people, but guaranteed the "right of each individual or group to remember the past in their own way." 282 Although these rights were guaranteed in the law, the rights of these groups to remember their own collective memory of the past did not extend to the public administration.

\footnotetext{
${ }^{278}$ Vincent, "Memory and oblivion since the Spanish Civil War," 48.

${ }^{279}$ Vincent, "Memory and oblivion since the Spanish Civil War," 47; Winter, "Thinking about silence," 18.

${ }^{280}$ Winter, "Thinking about silence," 23.

${ }^{281}$ Vincent, "Memory and oblivion since the Spanish Civil War," 63.

${ }^{282}$ Boyd, "The Politics of History and Memory," 145-146.
} 
Another stipulation of the Law of Historical Memory required "the retirement of shields, insignias, plaques and other objects or commemorative forms of exaltation, personal or collective, of the military uprising, of the Civil War and of the repression of the Dictatorship" by all public administration. As these symbols were objects of contention, the law sought to remove them to avoid future problems of offense and insult. ${ }^{283}$ However, this also was seen (especially by the PP) as an attack on the entire process of transition. The language of the law also contradicted some of the major goals it set out to do: namely honor all victims of the war. In the opposite of what the Franco regime did in postwar commemoration, the Law of Historical Memory only directly praised the efforts of Republican soldiers. ${ }^{284}$ The Spanish population agreed with the policies and politics of the PSOE enough that they were re-elected in the March 2008 elections.

The elections of 2008 proved that even the anger and vitriol which came from the PP in order to discredit Zapatero, the PSOE, and the 2004 election results could not overcome the shift which had occurred in the Spanish public opinion of the government in the 2000-2004 term of Aznar. Although the Socialists did not win an overall majority, they increased their number of seats in congress (though so too did the PP) by five. ${ }^{285}$ The results proved the shift in Spanish politics into a two-party dominated system was, if unstable, complete. As the PSOE had the initiative the PP had catching up to do before the next election period. ${ }^{286}$ The silence of the postwar period had been partially broken, but the dam was not completely broken in pieces and parts of it still held memories back. The vestiges of the dictatorship still loomed large in 2008 as the memory and the war memorials of the Nationalist victors still dominated much of the commemoration in Spain. ${ }^{287}$

The continued Civil War controversy post 11-M and post Law of Historical Memory was exemplified in the 2010 disbarment of Judge Garzón for opening an investigation into the alleged crimes against humanity committed by the Franco regime. The difference in the reaction

\footnotetext{
${ }^{283}$ Daniel E. Stofleth, "Memory Politics in Spain: The Law of Historical Memory and the Politics of the Dead," International Association of Genocide Scholars, Buenos Aires Conference, $9^{\text {th }}$ Conference (Buenos Aires, AR: July 19-22, 2011), 13.

${ }^{284}$ Stofleth, "The Law of Historical Memory and the Politics of the Dead," 14.

${ }^{285}$ Ivan Briscoe, "From the shadows: Spain's election lessons," openDemocracy.net, last modified March 11, 2008, accessed December 24, 2015, http://www.opendemocracy.net/article/democracy_power/politics_protest/spain_s_election_lessons.

${ }^{286}$ Briscoe, "Spain's election lessons."

${ }^{287}$ Casanova, "History and memory," 190.
} 
between his prosecution of Chilean dictator Augusto Pinochet in 1998 and the investigation of the Franco regime in 2010 was drastic as the Amnesty Law was violated by the investigation and, thus, the silence of the Franco dictatorship period remained. ${ }^{288}$ However, the breaking of the silence in the late 1990s to early 2000s of the Civil War period showed that the war itself was able to be reconciled. The 2007 Law of Historical Memory cemented that. The dictatorship, on the other hand, remains to the present-day as an unreconciled event that may not change until several generations of Spaniards have had enough time between the start of the transition period and the current democratic period. The political disagreements have grown more heated and the rifts between the PSOE and the PP have widened, continuing the identity theme of the "two Spains."

$\underline{\text { Two Spains Reincarnation }}$

The Civil War did not end in 1939. Violence continued against members of the Republic in the form of executions and imprisonments. As a means to secure his dictatorship, Franco divided Spain into winners and losers to keep alive the memory of the Civil War. The Republican vanquished were labeled as 'reds' to create an 'other', who were persecuted. The label was also indiscriminately applied to anyone deemed unworthy, thereby extending the atmosphere of fear throughout the society. Neighbors did not trust each other. Families were torn apart. Franco's alliance with the Catholic Church caused the ostracizing of large numbers of people. The generation born of the 'other' during the Franco era also suffered the loss of civil rights. Consequently, this 'apartheid' prevented a healing of the wounds of the Civil War and Spanish society was not able to move beyond the trauma. "This necessarily produced a schism between public and private memory in post-civil war Spain." 289

For the thirty-six years of the Franco regime, Spaniards lived in fear. Then after Franco died and the country transitioned to democracy, the political elites negotiating the transition were so fearful of another military rebellion that they instituted a total amnesty, which created a period of political silencing until the turn of the twenty-first century. The trauma of the Civil War continued. Two events during the early transition did lessen the "two Spains" divide. These

\footnotetext{
${ }^{288}$ Faber, "The Temptation of Spanish Exceptionalism," 117-118.

${ }^{289}$ Helen Graham, "The Spanish Civil War, 1936-2003: The Return of Republican Memory," Science \& Society 68, no. 3 (Fall 2004): 320-321.
} 
were the return of the exiled 'other' and the ratification of the 1978 constitution. However, tensions between the left and right continued and intensified when the PP won the 1996 election. Following the PSOE rediscovery of Civil War memory in 1999, the divide widened. During Aznar's second term, the divide widened more as Aznar implemented policies hearkening back to the Franco period.

Then the four days between the 11-M train bombings and the national election witnessed a major deepening of the divide between conservatives and liberals as millions of angry demonstrators took to the streets, questioning the integrity of the Aznar government. Tensions rose more as Aznar questioned the outcome of the election and initiated conspiracy theories about 11-M. Zapatero's first term saw the "two Spains" battle reach tension levels nearly equivalent to that just before the Civil War as the victors in the Civil War began to sense they were losing the propaganda battle over the war they had won. An opinion poll from 2006 in the middle of Zapatero's first term found that $54.6 \%$ of Spaniards believed that there were still two confronted Spains. Furthermore, the same poll found that $48.8 \%$ of Spaniards still talked about the Civil War. Why nearly half of Spain continued to discuss the Civil War may be due to the grandchildren of the vanquished wanting answers regarding the unrecovered memory. ${ }^{290}$ Considering the great modernization and economic improvement in Spanish life since the Civil War, it is surprising that the trauma lives on. Most Spaniards lived in pueblos or villages at the time of the Civil War. The split between left and right was at the village level. The hatred was personal. ${ }^{291}$ There may be two explanations for the grandchildren's demands. One is that the last people who actually experienced the War are dying and the opportunity for their voices to be heard is rapidly passing. Another may be that epigenetic changes in the parents of the grandchildren contributed to long-lasting fear and the continued telling of narratives. As indicated by the memory battles, there is no consensus in Spain about the past. Pierre Vilar's 1977 statement: "I now know that there are two 'memories' of any Spanish event" remains especially poignant. ${ }^{292}$

\footnotetext{
${ }^{290}$ Viejo-Rose, Reconstructing Spain, 162-165.

291 Tremlett, Ghosts of Spain, 26-29.

${ }^{292}$ Herbert R. Southworth, Guernica! Guernica!: A Study of Journalism, Diplomacy, Propaganda, and History (Berkeley: University of California Press, 1977), xvii.
} 


\section{SUMMARY AND CONCLUSIONS}

This study explored and analyzed the impact of the aftermath of the 2004 Madrid terrorist attacks on Spanish Civil War memory recovery viewed through the lens of the "two Spains" identity theme. The Civil War was initiated by a military (Nationalists) led coup d'état over a democratically elected leftist government (Republic) in 1936. Both sides committed atrocities, but the victorious Nationalists under Franco conducted a cleansing process as they captured Republic territory. After the end of the Civil War, Franco compounded the cleansing of Republicans by executing and imprisoning tens of thousands, especially during the Second World War. Even as late as the dedication of El Valle de los Caídos in 1959, Franco was saying "The anti-Spain was defeated and beaten, but it is not dead." 293 Many people today label the Franco cleansing as a "genocide" for which there has been no justice. ${ }^{294}$ Only the Franco side obtained justice; the Republicans only experienced more injustice. The Civil War and cleansing produced a bitter memory divide in Spain. During the early transition to democracy after Franco's death, an amnesty was granted to pardon all crimes committed by both sides in the Civil War and the Franco era. A 'pact of silence' was observed by politicians until nearly the turn of the twenty-first century. The transition emphasis on 'collective madness' of the Civil War and 'never again' was unsuccessful in overcoming the memory divide because it actually reinforced the Franco portrayal of the Civil War problem as 'fear of chaos' and the 'need for public order. ${ }^{295}$ Therefore, Spanish democracy was founded on injustice. Additionally, without any accountability for the Franco era, the elites from both sides created a political system prone to corruption, particularly nepotism in government and business. Despite the political accommodation of the transition, the unresolved memory divide persisted. ${ }^{296}$

One of the purposes of this study was to demonstrate that the Madrid terrorist attack and its aftermath intensified the recovery of memory and the breaking of silence in Spain. Silences over the personal memories of the Civil War began to break as early as the late 1970s and

\footnotetext{
293 Vincent, "Memory and oblivion since the Spanish Civil War," 59.

${ }^{294}$ Paul Preston, The Spanish Holocaust: Inquisition and Extermination in Twentieth-Century Spain (New York: W.W. Norton \& Company, Inc., 2012), xi-xx.

295 Antonio Gómez López-Quiñones, “A Secret Agreement: The Historical Memory Debate and the Limits of Recognition," Hispanic Issues On Line 11 (2012): 112.

${ }^{296}$ Paul Mason, "Unrest Drags Spain towards Unpleasant Truths," BBC.com, last modified, October 2, 2012, accessed September 3, 2015, http://www.bbc.com/news/business-19799572.
} 
increased during the memory boom of the late 1990s and following the creation of the ARMH. Political silence began to be broken with the first uncovering of a Civil War victim grave in 1999. As silence was increasingly fractured in the early years of the new century, it was apparent that the Civil War persisted as the principal generator of historical tensions between left and right political factions. This indicated that the long-standing differences were irreconcilable. At the time of 11-M, less than twenty percent of Spain's population remembered the Civil War, yet half the people still discussed the Civil War. 11-M initially induced a massive outpouring of grief, but the immediate aftermath quickly demonstrated Spain's ability to polarize as the memory debate became aggressively political. Acrimony over an unexpected election loss led the PP to actively work to undermine the legitimacy of Zapatero's win. A group of politicians, journalists, and demagogues led by Aznar and El Mundo began to spread conspiracy theories about 11-M. Thus 11-M reinvigorated the political warfare over Spain's past. The theme of "two Spains" had returned with a vengeance. As Zapatero tackled previous taboo issues, the political warfare intensified. Zapatero's push for a law to aid the recovery of Civil War memory greatly expanded the tribal warfare back to the divisions over the Civil War. The bitter and public political debate over 11-M and Civil War memory recovery fully fractured the silence of the transition.

In reality, both the PP and PSOE utilized the memory wars for their own purposes. Overall, Zapatero handled his acrimonious first term with good success as he expanded human rights and corrected past wrongs. The Law of Historical Memory has had positive results, but it has not been enough. Instead of bringing both the PP and PSOE together on issues, it has helped divide them even more. It also failed to provide reconciliation for victims of the Franco dictatorship, allowing that conflicted memory to also divide Spaniards. Regarding 11-M, the police investigation was quick and efficient and the judicial proceedings were thorough and effectively proved that ETA was not involved in 11-M. The conspiracy theories about 11-M were groundless propaganda by those Partido Popular politicians, supporters, and conservative media who sought to undermine the legitimacy of the Zapatero government. ${ }^{297}$ The second purpose of this study was accomplished by demonstrating by data and analysis that the social

\footnotetext{
${ }^{297}$ Guy Hedgecoe, “Spain's Politics of Memory,” openDemocracy.net, last modified March 11, 2010, accessed December 24, 2015, www.opendemocracy.net/guy-hedgecoe/spains-politics-of-memory.
} 
reaction to the immediate aftermath of 11-M was not fear but anger at both the terrorists and the government.

In many ways, Spain's response to 11-M was different than how other countries responded to terrorist attacks. At the time of 11-M Spain had a thirty-five year history of countering ETA terrorism. Spain learned at least three principal factors in dealing with ETA terrorism, which were also applied to international terrorism following 11-M. The foremost factor applied to ETA terrorism was to diminish popular support for the terrorists in both the Basque area and throughout Spain. This factor has been more difficult for Spanish action against international terrorism, but it is critical for the international community. A second factor was cooperation with other countries for intelligence gathering and for joint policing. This cooperation was with France for combating ETA. For international terrorism, Spain has mainly established cooperation with Morocco, the EU, and the United States. Joint counter-terrorism activities with Morocco have been very effective in preventing attacks. The third factor was aggressive policing, which has probably been the most useful factor Spain applied to international terrorism. Spain developed a body of law and organized law enforcement to deal with ETA terrorism. Spain utilized both national police and gendarmerie, the paramilitary Guardia Civil, to counter ETA. An important component was the establishment of counterterrorism commandos. Policing included comprehensive steps to counter terrorist financing, for covert action and infiltration, and for psychological operations. Other important components were long jail sentences to avoid released prisoner return to terrorism and wide dispersal of terrorist prisoners to avoid jails becoming terrorism schools. ${ }^{298}$

Following 11-M, Spain implemented two significant changes to their counter-terrorism policies. One was to reorganize and expand their security and intelligence agencies to deal with international terrorism. As part of the expansion, Spain established a central agency for counterterrorism information coordination, the Centro Nacional de Coordinación Antiterrorista. The second change was to reform and update terrorism laws, including reforms needed to meet U.N. resolutions and EU directives. What is notable about Spain's counter-terrorism measures are that they are based on law enforcement and not on military operations. An important element in the legal framework is that Spain considers terrorism a national problem; hence, all terrorism cases

\footnotetext{
${ }^{298}$ Christopher C. Harmon, “Spain’s ETA Terrorist Group is Dying,” Orbis Journal, (Fall 2012): 589-601.
} 
are heard and tried by the National High Court, the Audiencia Nacional. ${ }^{299}$ Spain also implemented more controversial laws that removed some constitutional guarantees for terrorist detainees. These laws include incommunicado detention (solitary confinement) for up to thirteen days without legal representation and pretrial detention for up to four years. ${ }^{300}$ Recognizing the immigration integration problem and its association with radicalization, Spain in 2007 established a multidimensional strategic plan to improve immigrant integration through education, employment, housing, social services, health services, etc. ${ }^{301}$

What has been the outcome of Spain's counter-terrorism policies? With tranquility and authority and without nationalistic paranoia or saber-rattling, Spain tried and convicted the terrorists responsible for 11-M within three and one half years of the attacks. ${ }^{302}$ By the tenth anniversary of 11-M, Spain had arrested at least 472 suspected Islamist militants and was maintaining a force of 1,800 police and security dedicated to counter-terrorism. ${ }^{303}$ Between 2011 and 2014, Spain broke up more terrorist cells than any other European country. ${ }^{304}$ In France following the Hebdo attack of January 2015, Spain's President of the Government, Mariano Rajoy emphasized "...that to combat terrorism, or at least that is the experience many of us in Spain have, we must adopt an attitude of fighting ceaselessly." ${ }^{305}$ An Islamic Commission of Spain (CIE), which was set up in 1992 as a liaison between the government and the Muslim population, has been an important factor in reducing support for terrorism within Spain. The Commission has provided a voice for the Muslim community and has negotiated with the government to obtain and assure civil rights. ${ }^{306}$ There was very little anti-Muslim violence following 11-M. The reason why may be that Spain is one of the most religiously tolerant

\footnotetext{
${ }^{299}$ FRIDE WP 6, Del. 12b. Final, "Case Study: Spain, The Ethical Justness of Counter-Terrorism,” (Madrid: Fundación para las Relaciones Internacionales y al Dialogo Exterior, 27 October 2008), 7-12.

${ }^{300}$ FRIDE, “Case Study: Spain," 19-20.

301 José Antonio Peña-Ramos and Iván Medina, "Interpreting Muslim Religious Interest Groups in Spain: Frames, Organisation and Influence." Journal of US-China Public Administration 8, no. 4 (April 2011): 390.

${ }^{302}$ Fred Halliday, “Justice in Madrid: the '11-M' Verdict," openDemocracy.net, last modified 30 October 2007, accessed December 24, 2015, http://www.opendemocracy.net/article/justice in madrid the 11m_verdict.

${ }^{303} \mathrm{Al}$ Goodman, "Spain Arrests 6 Suspected of Recruiting for Terror Groups," CNN.com, Madrid, last modified May 30, 2014, accessed September 14, 2014, http://www.cnn.com/2014/05/30/world/spain-terrorist-arrests/.

${ }^{304}$ Carlotta Gall, "Spanish Police Target Cells Recruiting War Volunteers," New York Times, Melilla, Spain, June 16, 2014, accessed December 2, 2014, http://www.nytimes.com/2014/06/17/world/europe/spanish-police-targetcells-recruiting-war-volunteers-for-insurgencies-from-western-africa-syria-iraq.html.

${ }^{305}$ Mariano Rajoy, "Statement by President of the Government at Spanish Embassy in French Republic," Gobierno de España, La Moncloa, 11 January 2015.

${ }^{306}$ Geoff Pingree and Lisa Abend, "In Spain, Dismay at Muslim Converts Holding Sway," Christian Science Monitor, Madrid, last modified November 7, 2006, accessed September 17, 2014, http://ww.csmonitor.com/layout/set/print/2006/1107/p04s01-woeu.html.
} 
countries in Europe, an outcome of the backlash from the Catholic Church repression during the Franco period. An additional reason may be because anger immediately after 11-M turned from the terrorists to the government. ${ }^{307}$ Also, there has not been any anti-immigrant movement within Spain. Restraint within Spain has been amazing and is a tribute to the democracy formed after Franco. ${ }^{308}$

In contrast, the United States' response to terrorism has been different in many ways. Fifteen years after 9/11, the U.S. has not put on trial any of the responsible terrorists. Guantánamo remains open with suspected terrorists in limbo. Terrorists have been placed in common detention in Guantánamo, Iraq, and Afghanistan, thereby creating terrorism schools. Released prisoners have typically returned to terrorism. The leader of the Islamic State in Iraq and Syria (ISIS) came out of one of the Iraq detention camps. The U.S. engaged principally in military response with flawed outcomes in Iraq, Afghanistan, Libya, and Syria. Local and national police (F.B.I.) in the U.S. have been generally effective preventing large terrorist attacks. Very large-scale electronic monitoring of communications has occurred. Counterterrorism commandos have not been necessary within the U.S. because there has not been an organized international terrorism group within the country. Some politicians have been taking advantage of increasing xenophobia to gain voter support.

Although the election of 2004 following 11-M was a bracing validation of democracy, it is not remembered that way because the horror of 11-M did not heal, but instead exacerbated deep ideological divisions between left and right. Ironically, ETA terrorism had actually united politicians and the people to reject the ETA. ${ }^{309}$ Since 2008 in Spain, the difficult economic situation with its associated high unemployment has been undermining social and political progress. Zapatero won a second term in 2008, but the world-wide economic crisis hit Spain hard. The Spanish economic miracle was over. Earlier enormous over-construction had produced massive debt. The government was forced into austerity measures by the European Union and had to take bailouts for banks. Unemployment skyrocketed and protests about economic inequality broke out across Spain. By 2011, Zapatero's popularity had plummeted and

\footnotetext{
${ }^{307}$ Murado, "Madrid Bombings, 10 Years On."

${ }^{308}$ Hisham Aidi, "Spain Still Uneasy with the Moors," Al Jazeera.com, last modified January 24, 2015, accessed February 10, 2015, http://www.aljazeera.com/indepth/opinion/2015/01/spain-uneasy-moors20151247022860174.html.

${ }^{309}$ Hedgecoe, "Spain's Politics of Memory."
} 
the PP under Mariano Rajoy won the November 2011 national election. However, political crisis and protests continued with a clash over economic, social, and political class divisions and economic injustice (inequality), which brought a resurgence of allusions to the Civil War and the "two Spains" theme. In 2014, King Juan Carlos I abdicated in the midst of corruption within the monarchy and Catalonia independence was aggressively pushed. The continuing economic crisis lessened support for both the PP and PSOE parties and two new national parties, leftwing antiausterity Podemos and pro-EU Ciudadanos gained substantial support. ${ }^{310}$ The national elections of December 2015 effectively ended the two-party political system as no party won a majority. Coalition government has become the new political reality. It is likely that Spain is moving toward a more typical European Union political system with a diversity of ideologies. Time will tell if the new several party system ends the "two Spains" identity theme or creates a new 'multiple Spains' theme by developing more than two non-reconcilable positions.

${ }^{310}$ Sahagún, "Leaders of a Divided Spain.” 


\section{RECOMMENDATIONS}

The process of Civil War memory recovery and healing traumatic memory is not finished. Victim graves remain to be uncovered and their remains properly reburied. Victim mourning cannot be completed until reburials are brought to a close. Vincent stated that recovery of the past requires "a rewriting, a new narration of the past to reflect the agency of those in the present." 311 A common narrative of the Civil War and Franco era is particularly difficult to achieve when the memory war is presented as a moral struggle between irreconcilable social and political positions. Furthermore, the scales of injustice are not balanced. Can healing of the trauma be achieved without justice? The time for justice in Spain is almost past with most of the guilty dead. Why has Spain not had truth and reconciliation commissions, which are considered under international law to be the standard for handling transitional justice? According to Blakeley, the Spanish transition to democracy, with the Amnesty Law of 1977 and the Constitution of 1978, was founded on political conciliation, not social reconciliation. Continued fear from repression during the Franco regime and concern about the potential for a military coup drove political consensus. There actually were attempts to recover historical memory, including recovery and reburial of victims, during the early years of the transition, but the military coup attempt of 1981 ended these attempts. The political elite concluded that the Spanish democracy could not withstand confronting the past and consensus politics ruled for the remainder of the twentieth century. ${ }^{312}$

With the breaking of silence, the ARMH in August 2002 attempted to force Spain to meet its international obligations by taking the case of recovering the 'disappeared' to the U.N. High Commission for Human Rights. The case did provide impetus for the Spanish Congress of Deputies to unanimously approve the November 2002 resolution which condemned the military coup of $1936 .{ }^{313}$ Although the PP had bowed to pressure, the party counter-reacted and included in the resolution that the issue of "two Spains" would be removed from politics, which was an attempt to bring closure to the issue of the Civil War and avoid the truth. The PP was also using the resolution as a way to prolong consensus politics. ${ }^{314}$ Then in 2005 Amnesty International

\footnotetext{
${ }^{311}$ Vincent, "Memory and oblivion since the Spanish Civil War," 66.

${ }^{312}$ Blakeley, "Consequences of Truth and Reconciliation," 51-53.

${ }^{313}$ Ibid., 48-50.

${ }^{314}$ Ibid., 55-56.
} 
requested Spain to deal with its 'disappeared' and in 2006 the Council of Europe condemned the Franco regime. A local first truth commission was established in Valencia in February 2007 to investigate post-Civil War repression, but it expressly did not deal with the Civil War. ${ }^{315}$ The 2007 Law of Historical Memory seemed to finally start Spain on the path to do something about the 'disappeared,' but the Law was not adequately funded and when the PP government of Mariano Rajoy came to power in 2011, the budget for the Law was eliminated. The U.N. in 2014 again recommended that Spain take action to recover the 'disappeared' and to establish a truth commission, but Rajoy did not take action. ${ }^{316}$ More than one hundred of the Associations involved in memory recovery in Spain set up a Platform for a Truth Commission in 2013 to call for Spain to fulfill the U.N. resolutions and to establish "a parliamentary truth commission to recognize the victims of Franco and establish the facts." The campaign also called for the repeal of the 1977 Amnesty Law that prevents judicial investigations of crimes of the Civil War and the Franco dictatorship. ${ }^{317}$ However, Spanish government action has not occurred. Clearly, the PP remains intransigent, but the PSOE had opportunities to do more. Why are Spanish politicians not taking action? Blakeley answered this question as being a failure of Spanish democracy to consolidate after the transition.

A key difference between mature, consolidated democracies and transitional democracies is that the normal political situation for consolidated democracies is political conflict within legitimate political institutions; whereas for transitional democracies the norm is political consensus. Spain has experienced unending consensus politics with both conservative and liberal politicians striving to resolve issues outside of politics. This may be partly a legacy of Franco's "I don't get involved in politics" statement or from fear of political conflict or lack of political will. $^{318}$ It is more likely that the long-term balance between the conservative and liberal political parties and their alternating governments helped drive the prolonged consensus politics. The political conflict arising in the aftermath of 11-M may have started the end of the transition and its consensus politics. The long-term balance between the two political wings has also been

\footnotetext{
${ }^{315}$ Viejo-Rose, "Reconstructing Spain," 162-163.

316 James Badcock, "Spain Exhumes Civil War Victim as Calls Grow for Truth Commission," Telegraph, Madrid, last modified January 19, 2016, accessed April 21, 2016, http://www.telegraph.co.uk/news/worldnews/europe/spain/12106843/Spain-exhumes-civil-war-victim-as-callsgrow-for-truth-commission.html.

${ }^{317}$ Agence France Presse, "Victims Demand Franco Truth Commission in Spain," Arab News, last modified October 4, 2015, accessed April 21, 2016, http://www.arabnews.com/news/814986.

${ }^{318}$ Blakeley, "Consequences of Truth and Reconciliation," 54-55.
} 
shattered by the current four-party situation. Maybe the multi-party situation is the beginning of consolidated democracy, but it is nearly too late for truth commissions to achieve any justice. Since prosecutions following a truth commission are becoming less likely as time passes, are there options for reconciliation and memory recovery without justice?

International law for transitional justice is based on morality. Is there a moral position that satisfies memory recovery without justice? López-Quiñones discussed that memory recovery in a democracy is a civil rights-based process in which the principles of integration (assimilation), inclusion of excluded elements, appeasement (making opposites compatible), and resolution (reconciliation between adversaries) are promoted. Furthermore, he argued that "In this implicit characterization of democracy, common ground and compromise in the name of the greater good have the upper hand over antagonism and unmitigated opposition between different political preferences." 319 One of the generally accepted maxims from the Holocaust is that history is morally obligated to remember the crimes. Additionally, the trauma theory discussion in this thesis mentioned that Holocaust survivors have a compelling need to tell their stories. López-Quiñones also pointed out that "identity is partly shaped by recognition or its absence."320 Following the above principles and based on the ideas of remembrance, recording of names and stories, identity shaped by recognition, recovery of the missing, and rewriting a new narrative, it is feasible to postulate a possible solution to the moral question of securing memory recovery without justice.

In reference to the memory of the Spanish Civil War, López-Quiñones suggested that: "There ought to be an institutionally promoted approach to this crucial past because the past (a particular version of it) should work as a tool to sponsor a set of values." 321 Building on his suggestion and with an overall objective to obtain moral closure for the Civil War, it is recommended that Spain depoliticize the memory debate by establishing an independent, neutral institution to fully investigate all victims and atrocities of the Civil War and the Franco regime for the purposes of remembrance of victims and crimes, recording of names and stories, recognizing the victims, assuring recovery of the missing, and rewriting a truthful history of the crimes perpetuated on victims from both sides. It is additionally recommended that the

\footnotetext{
${ }^{319}$ López-Quiñones, “A Secret Agreement,” 94-97.

${ }^{320}$ Ibid., 99.

${ }^{321}$ Ibid., 97-98.
} 
institution avoid being involved in pursuit of justice and its associated political conflict. The institution must produce an official accounting of all atrocities and victims and promote an open, unbiased discussion of the truth. The issue of the Civil War can only be solved when both sides are awarded recognition. ${ }^{322}$ Jordi Gordon, spokesperson for the Platform for Truth Commission, emphasized "Spain has a blot on its entire democratic trajectory, which are the crimes committed under Francoism. A democratic state in Spain can only be truly democratic if it recognizes what Francoism was. ${ }^{, 323}$ To avoid a fracturing of the nation, it is also recommended that Spain initiate a second transition to find national commonality.

${ }^{322}$ Blakeley, "Consequences of Truth and Reconciliation," 55.

${ }^{323}$ Ellis O’Neill, “Spaniards Want Truth on Franco's Crimes,” Volunteer, last modified September 14, 2013, accessed April 21, 2016, http://www.albavolunteer.org/2013/09/spaniards-call-for-truth-commission-on-francoscrimes/. 


\section{BIBLIOGRAPHY}

\section{Primary Sources:}

Abend, Lisa. "Five Years after the Madrid Bombings." Time, March 11, 2009. http://content.time.com/time/printout/0,8816,1884231,00.html.

Agence France Presse. "Victims Demand Franco Truth Commission in Spain.” Arab News. Last modified October 4, 2015. http://www.arabnews.com/news/814986.

Aidi, Hisham. "Spain Still Uneasy with the Moors." Al Jazeera.com. Last modified January 24, 2015. http://www.aljazeera.com/indepth/opinion/2015/01/spain-uneasy-moors20151247022860174.html.

Aznar, José María. "Declaración Íntegra de José María Aznar sobre los Atentados de ETA en Madrid." www.junjan.org/weblog/documents/documento_aznar_11M.html, accessed February 24, 2015.

Badcock, James. "Spain Exhumes Civil War Victim as Calls Grow for Truth Commission." Telegraph, Madrid, January 19, 2016. Accessed April 21, 2016. http://www.telegraph.co.uk/news/worldnews/europe/spain/12106843/Spain-exhumescivil-war-victim-as-calls-grow-for-truth-commission.html.

“Constitución Política de la Monarquía Española promulgada en Cádiz a 19 de marzo de 1812.”

Corera, Gordon. "The Legacy of the Madrid Bombings." BBC News. Last modified February 15, 2007. http://news.bbc.co.uk/2/hi/europe/6357599.stm.

Editorial. “11-M.” El País, March 12, 2004.

Editorial. "Después de la matanza.” El País, March 13, 2004.

Editorial. "Nuestro 11-S.” El Mundo, March 12, 2004.

Editorial. "Un presidente para hoy, un relevo para mañana.” El Mundo, March 13, 2004.

“E1 92\% de los Españoles se Opone a la Guerra Contra Irak.” Clarín.com. March 29, 2003. http://edant.clarin.com/diario/2003/03/29/um/m-537495.htm.

Figueras, Amanda. “Al Qaeda Dice Sentirse 'Orgullosa' de la Destrucción que Afectó a Madrid el 11-M.” El Mundo, August 6, 2007. Accessed September 14, 2014. http://www.elmundo.es/elmundo/2007/08/06/internacional/1186414637.html. 
Fuchs, Dale. “Aznar Accused on Madrid Bombing." Guardian, Madrid, June 22, 2005. Accessed September 4, 2015. http://www.theguardian.com/world/2005/jun/23/spain.dalefuchs.

“Full Text: 'Al-Qaeda' Madrid Claim.” BBC News. Last modified March 14, 2004. http://news.bbc.co.uk/2/hi/europe/3509556.stm.

Gall, Carlotta. "Spanish Police Target Cells Recruiting War Volunteers." New York Times, Melilla, Spain, June 16, 2014. Accessed December 2, 2014. http://www.nytimes.com/2014/06/17/world/europe/spanish-police-target-cells-recruitingwar-volunteers-for-insurgencies-from-western-africa-syria-iraq.html.

Goodman, Al. "Spain Arrests 6 Suspected of Recruiting for Terror Groups." CNN.com. Madrid, last modified May 30, 2014. http://www.cnn.com/2014/05/30/world/spain-terroristarrests/.

Gordon, Philip H. "Madrid Bombings and U.S. Policy." Brookings Institute, Testimony to Senate Committee on Foreign Relations, March 31, 2004.

Halliday, Fred. “Justice in Madrid: the '11-M' Verdict." openDemocracy.net. Last modified 30 October 2007. http://www.opendemocracy.net/article/justice_in_madrid_the_11m_verdict.html.

Ham, Anthony. "Battle for the Soul of Spain." The Age, Madrid, March 8, 2008.

Hamilos, Paul. "The Worst Islamist Attack in European History." Guardian, Madrid, October 31, 2007. Accessed July 15, 2014. http://www.theguardian.com/world/2007/oct/31/spain/print.

Hughes, Dominic. "Views from Madrid on Bomb Verdict." BBC News. Madrid, last modified October 31, 2007. http://newsvote.bbc.co.uk/mpapps/pagetools/print/news.bbc.co.uk/2/hi/europe/7071975.st $\underline{\mathrm{m}}$.

Junquera, Natalia. "Victims Put Aside 10 Years of Difference over 11-M to Remember Loved Ones." El País in English. Madrid, last modified March 12, 2014. http://elpais.com/m/elpais/2014/03/12/inenglish/1394625516_511144.html.

Karon, Tony. “Did al-Qaeda Change Spain's Regime?” Time, March 15, 2004. http://content.time.com/time/printout/0,8816,601306,00.html.

Leiken, Robert S. and Steven Brooke. "Who is Abu Zarqawi?" CBS News.com, Weekly Standard. Last modified May 18, 2004. http://www.cbsnews.com/news/who-is-abuzarqawi/. 
Maclean, William. "New Evidence of Qaeda Tie to Madrid Blast: Expert." Reuters.com. Last modified January 12, 2010. http://www.reuters.com/assets/print?aid=USTRE60B52020100112.

"Madrid Memorial for Train Victims." BBC News. Published March 11, 2007. http://newsvote.bbc.co.uk/mpapps/pagetools/print/news.bbc.co.uk/2/hi/europe/6439825.st m.

Mason, Paul. "Unrest Drags Spain Towards Buried Unpleasant Truths." BBC.com. Last modified October 2, 2012. http://www.bbc.com/news/business-19799572.

Murado, Miguel-Anxo. "Madrid Bombings, 10 Years on: the Lack of a Backlash Has the Power of a New Guernica." Guardian, Madrid, March 11, 2014. Accessed September 4, 2015. http://www.theguardian.com/commentisfree/2014/mar/11/madrid-bombings-guernicaconspiracy-islamists-eta.

O’Neill, Ellis. "Spaniards Want Truth on Franco's Crimes." Volunteer. Last modified September 14, 2013. http://www. albavolunteer.org/2013/09/spaniards-call-for-truth-commission-onfrancos-crimes/.

Pingree, Geoff and Lisa Abend. "In Spain, Dismay at Muslim Converts Holding Sway." Christian Science Monitor. Madrid, last modified November 7, 2006. http://ww.csmonitor.com/layout/set/print/2006/1107/p04s01-woeu.html.

Rajoy, Mariano. "Statement by the President of the Government at Spanish Embassy in French Republic.” Gobierno de España, La Moncloa. Published January 11, 2015.

Rothstein, Edward. "Was the Islam of Old Spain Truly Tolerant?" New York Times, September 27, 2003. Accessed September 9, 2014. http://www.nytimes.com/2003/09/27/arts/wasthe-islam-of-old-spain-truly-tolerant.html.

Sciolino, Elaine, Lizette Alvarez and Dale Fuchs. "Bombings in Madrid: Reaction; Grieving Crowds in Spain Seethe at Train Attacks." New York Times, March 13, 2004. Accessed February 24, 2015. http://www.nytimes.com/2004/03/13/world/bombings-in-madridreaction-grieving-crowds-in-spain-seethe-at-train-attacks.html.

Serna, Victor de la. "Madrid's Vanished Horror." Guardian, Madrid, July 8, 2005. Accessed September 14, 2014. http://www.theguardian.com/world/2005/jul/08/spain.terrorism/print.

"The Madrid Bomb Trials: Historic Verdicts." Economist, Madrid, November 1, 2007. Accessed September 4, 2015. http://www.economist.com/node/10064645/print.

Tremlett, Giles. "Aznar Asserts Ties between ETA and Islamists over Madrid Terror Attack." Guardian, Madrid, November 29, 2004. Accessed September 4, 2015. http://www.theguardian.com/world/2004/nov/30/spain.gilestremlett. 
------. “Aznar 'Wiped Files on Madrid Bombings'.” Guardian, Madrid, December 13, 2004. Accessed September 4, 2015. http://www.theguardian.com/world/2004/dec/14/spain.gilestremlett.

Wright, Lawrence. "The Terror Web.” New Yorker, August 2, 2004. http://www.newyorker.com/magazine/2004/08/02/the-terror-web.

Zapatero, José Luis Rodríquez. "Statement by the President of the Government of Spain, Mr. José Luis Rodríquez Zapatero, at the $59^{\text {th }}$ Session of the United Nations General Assembly.” New York, September 21, 2004.

\section{Secondary Sources:}

Abrahms, Max. "Why Terrorism Does Not Work." International Security 31, no. 2 (Fall 2006): $42-78$.

Aguilar, Paloma. Memory and Amnesia: the Role of the Spanish Civil War in the Transition to Democracy, translated by Mark Oakley. New York: Berghahn Books, 2002.

Arredondo, Christopher Britt. Quixotism: The Imaginative Denial of Spain's Loss of Empire. Albany: State University of New York, 2005.

Baird Jr., William E. "The Madrid Train Bombings: A Decision-Making Model Analysis." master's thesis, U.S. Army Command and General Staff College, 2009.

Balfour, Sebastian, ed. The Politics of Contemporary Spain. New York: Routledge, 2005.

-----. "Introduction: Spain since the transition to democracy: an overview." In Balfour, 1-5.

-----. "The Reinvention of Spanish conservatism: The Popular Party since 1989." In Balfour, 146-168.

Balcells, Laia. "The Consequences of Victimization on Political Identities: Evidence from Spain." Journal of Politics \& Society 40, no. 3 (2012): 311-347.

Barella, Julia. "Luz Blanca." Madrid, Once de Marzo: Poemas para el Recuerdo. Edited by Eduardo Jordá and José Mateos. Valencia: Pre-Textos, 2004, 24.

Bermeo, Nancy. "Myths of Moderation: Confrontation and Conflict during Democratic Transitions." Journal of Comparative Politics 29, no. 3 (April 1997): 305-322.

Bezunartea, Patricia, José Manuel López, and Laura Tedesco. "Muslims in Spain and Islamic Religious Radicalism.” MICROCON Policy Working Paper 8, Brighton: MICROCON, May 2009. 
Birnbaum, Norman. "Spain's Recent History: Rebirth of a Nation." The Euromedia Blog, entry posted March 16, 2004.

http://journalism.berkeley.edu/projects/euromedia/archives/002326.html.

Blakeley, Georgina. "Digging up Spain's Past: Consequences of Truth and Reconciliation." Democratization 12, no. 1 (February 2005): 44-59.

Boyd, Carolyn P. "The Politics of History and Memory in Democratic Spain." Annals of the American Academy of Political and Social Science 617 (May, 2008): 133-148.

Briscoe, Ivan. "From the shadows: Spain's election lessons." openDemocracy.net, last modified March 11, 2008.

http://www.opendemocracy.net/article/democracy_power/politics_protest/spain_s_electio $\underline{\mathrm{n} \_ \text {lessons. }}$.

Canetti-Nisim, Daphna, Eran Halperian, Keren Sharyit, and Stevan E. Hobfoll. "A New StressBased Model of Political Extremism: Personal Exposure to Terrorism, Psychological Distress, and Exclusionist Political Attitudes." J. of Conflict Resolution 53, no. 2 (June 2009): 363-389.

Cardús i Ros, Salvador. "Politics and the Invention of Memory, For a Sociology of the Transition to Democracy in Spain," in Disremembering the Dictatorship: The Politics of Memory in the Spanish Transition to Democracy. Edited by Joan Ramon Resina. Atlanta: Editions Rodopi B.V., 2000.

Canel, María-José. "Communicating strategically in the face of terrorism: The Spanish government's response to the 2004 Madrid bombing attacks." Public Relations Review 38 (2012): 214-222.

Casanova, Julián. "History and Memory: A New Social Dimension." International Journal of Iberian Studies 21, no. 3 (2008): 187-202.

Chari, Raj S. “The 2004 Spanish Election: Terrorism as a Catalyst for Change?” West European Politics 27, no. 5 (November, 2004): 954-963.

Edkins, Jenny. Trauma and the Memory of Politics. New York: Cambridge University Press, 2003.

Encarnación, O.G. Spanish Politics: Democracy after Dictatorship. Malden: Polity Press, 2008.

Faber, Sebastiaan. "The Debate about Spain's Past and the Crisis of Academic Legitimacy: The Case of Santos Juliá." The Colorado Review of Hispanic Studies 5, (Fall 2007): 165-190. 
-----. "Revis(it)ing the Past: Truth, Justice, and Reconciliation in Post-Franco Spain, a ReviewArticle (Second Part)." Revista Hispánica Moderna 59, no. 1/2 (Jun. - Dec., 2006): 141154.

-----. "Raising the Specter of "Argentinization": The Temptation of Spanish Exceptionalism." Hispanic Issues On Line, (Fall 2012): 117-136.

Farrell, Mary. "Spain in the new European Union: in search of a new role and identity." In Balfour, 215-234.

FRIDE WP 6, Del. 12b, Final. Case Study: Spain, the Ethical Justness of Counter-Terrorism Measures. Madrid: Fundación para las Relaciones Internacionales y al Dialogo Exterior, October 27, 2008.

Gaddis, John Lewis. The Landscape of History: How Historians Map the Past. New York: Oxford University Press, 2002.

Graham, Helen. "Coming to Terms with the Past: Spain's Memory Wars." History Today 54, no. 5 (May 2004): 29-31.

-----. “The Spanish Civil War, 1936-2003: The Return of Republican Memory.” Science \& Society 68, no. 3 (Fall 2004): 313-328.

Gunther, Richard, José Ramón Montero, and Joan Botella. Democracy in Modern Spain. New Haven: Yale University Press, 2004.

Hałas, Elżbieta. "Issues of Social Memory and their Challenges in the Global Age," Time \& Society 17, no. 1 (2008): 103-118.

Harmon, Christopher C. "Spain's ETA Terrorist Group is Dying." Orbis Journal (Fall, 2012): 588-607.

Hedgecoe, Guy. "Spain's Politics of Memory." openDemocracy.net. Last modified March 11, 2010. http://www.opendemocracy.net/guy-hedgecoe/spains-politics-of-memory.

Hopkin, Jonathan. "From consensus to competition: the changing nature of democracy in the Spanish transition." In Balfour, 6-26.

Jesús, Carlos Echeverría. "The Current State of the Moroccan Islamic Combatant Group," CTC Sentinel 2, no. 3 (March 2009): 22-24.

Jordá, Eduardo y José Mateos. Madrid, Once de Marzo: Poemas para el Recuerdo. Valencia: Pre-Textos, 2004.

Juliá, Santos Díaz. Historias de las dos Españas. Madrid: Taurus, 2004. 
-----. “Un año de oposición.” El País, May 2, 2005.

Labanyi, Jo. "Memory and Modernity in Democratic Spain: The Difficulty of Coming to Terms with the Spanish Civil War." Poetics Today 28, no. 1 (Spring 2007): 89-116.

Larra, Mariano José de. "El día de Difuntos de 1836: Figaro en el cementario." El Español, no. 368 (November 2, 1836).

Lerner, Jennifer S. and Dacher Keltner, "Fear, Anger, and Risk," Journal of Personality and Social Psychology 81, no. 1 (2001): 146-159.

Levitt, Joshua. "Analysis: On $10^{\text {th }}$ Anniversary of Madrid Al Qaeda 3-11 Bombing, Analysts Apply Lessons to Fight Terror in Israel." Algemeiner. Last modified March 11, 2014. http://www.algemeiner.com/2014/03/11/analysis-on-10th-anniversary-of-madrid-alqaeda-3-11-bombing-analysts-apply-lessons-to-fight-terror-in-israel/.

López-Quiñones, Antonio Gómez. "A Secret Agreement: The Historical Memory Debate and the Limits of Recognition.” Hispanic Issues On Line (Fall 2012): 87-116.

Manganas, Nicholas. "Mass-Mediated Social Terror in Spain." CLCWeb: Comparative Literature and Culture. 9, no.1 (2007), Article 10: 1-14.

Menocal, María Rosa. The Ornament of the World: How Muslims, Jews, and Christians Created a Culture of Tolerance in Medieval Spain. New York: Little, Brown, and Company, May, 2002.

Miguel-Tobal, Juan J., Antonio Cano-Vindel, Hector Gonzales-Ordi, Iciar Iruarrizaga, Sasha Rudenstine, David Vlahoy, and Sandro Galea, "PTSD and Depression After the Madrid March 11 Train Bombings," Journal of Traumatic Stress 19, no. 1 (February 2006): 6980 .

Miquel, Mathieu. "March 11, 2004. The Madrid 3/11 Bombings: Was It Really an Attack by 'Islamic Terrorists'?" The Centre for Research on Globalization, December 6, 2009.

Moreno, Luis. "The Madrid Bombings in the Domestic and Regional Politics of Spain." Irish Studies in International Affairs 16 (2005): 67-72.

Nora, Pierre. "'Between History and Memory: les lieux de mémoire." Representations 26 (1989): 7-24.

-----. Les Lieux de Mémoire. (Gallimard: Paris, 1984). In Memory and Amnesia: the Role of the Spanish Civil War in the Transition to Democracy. Edited by Paloma Aguilar. Translated by Mark Oakley. New York: Berghahn Books, 2002.

Núñez Seixas, Xosé-Manoel. "From National-Catholic nostalgia to constitutional patriotism: conservative Spanish nationalism since the early 1990s." In Balfour, 121-145. 
Olmeda, José A. "Fear or Falsehood? Framing the 3/11 Terrorist Attacks in Madrid and Electoral Accountability." Working Paper (WP) 24/2005, Real Instituto Elcano, May 5, 2005.

Peña-Ramon, José Antonio and Iván Medina. "Interpreting Muslim Religious Interest Groups in Spain: Frames, Organisation and Influence." Journal of US-China Public Administration 8, no. 4 (April 2011): 387-400.

Preston, Paul. The Spanish Holocaust: Inquisition and Extermination in Twentieth-Century Spain. New York: W.W. Norton \& Company, Inc., 2012.

------. "The monarchy of Juan Carlos: From dictator's dreams to democratic realities," In Balfour, 27-38.

Radley, Jason J., Mohamed Kabbai, Lauren Jacobson, Willem Heydendael, Rachel Yehuda, and James P. Herman, "Stress Risk Factors and Stress-Related Pathology: Neuroplasticity, Epigenetics and Endophenotypes.” Stress 14, no. 5 (September 2011): 481-497.

Reinares, Fernando. "Jihadist Radicalization and the 2004 Madrid Bombing Network." CTC Sentinel 2, no. 2 (November 2009): 16-19.

------. ;Matadlos! Quién Estuvo Detrás del 11-M y por qué se Atentó en España [Kill Them! Who was Behind 11-M and Why Spain was Targeted.]. Barcelona: Galaxia Gutenberg, 2014.

------. "The Evidence of Al-Qàida's Role in the 2004 Madrid Attack." CTC Sentinel 5, no. 3 (March 2012): 1-6.

-------. “Los Planes Pendientes Tras el 11-M.” El País Opinión, April 7, 2014.

Richards, Michael. A Time of Silence: Civil War and the Culture of Repression in Franco's Spain, 1936-1945. Cambridge: Cambridge University Press, 1998.

Ricoeur, Paul. Memory, History, Forgetting. Translated by Kathleen Blamey and Daniel Pellauer, Chicago: The University of Chicago Press, 2004.

Robbins, Jill. "Memorials, Shrines and Umbrellas in the Rain: Poetry and 11-M." Studies in $20^{\text {th }}$ \& $21^{\text {st }}$ Century Literature 36, no. 2 (2012), Article 14: 391-408.

Rose, William, Rysia Murphy and Max Abrahms. "Does Terrorism Ever Work? The 2004 Madrid Train Bombings.” International Security 32, no. 1 (Summer, 2007): 185-192.

Sahagún, Felipe. "Leaders of a Divided Spain Square Off Yet Again.” Stratfor Global Intelligence, August 3, 2014. 
Sinkkonen, Teemu. "Political Responses to Terrorism: Case Study on the Madrid Terrorist Attack on March 11, 2004, and Its Aftermath." PhD diss., University of Tampere, 2009.

Southworth, Herbert R. Guernica! Guernica!: A Study of Journalism, Diplomacy, Propaganda, and History. Berkeley: University of California Press, 1977.

Stofleth, Daniel E. "Memory Politics in Spain: The Law of Historical Memory and the Politics of the Dead." International Association of Genocide Scholars, Buenos Aires Conference, $9^{\text {th }}$ Conference. Buenos Aires, AR: July 19-22, 2011.

Tarrow, Sidney C. Power in Movement: Social Movements and Contentious Politics. Cambridge: Cambridge University Press, 1994.

Tojar, Luis García. "11-M: A Lesson on Greedy Journalism." International Review of Sociology 20, no. 1 (2010): 77-91.

Treglown, Jeremy. “A Heartless Craft: Spain's History Wars.” The Dublin Review no. 28, (Autumn 2007): 34-57.

Tremlett, Giles. Ghosts of Spain: Travel through Spain and Its Silent Past. New York: Walker and Company, 2006.

Trouillot, Michel-Rolph. Silencing the Past: Power and the Production of History. Boston: Beacon Press, 1995.

Viejo-Rose, Dacia. Reconstructing Spain: Cultural Heritage and Memory after Civil War. Eastbourne, U.K.: Sussex Academic Press, 2011.

Vincent, Mary. "Breaking the silence? Memory and oblivion since the Spanish Civil War." In Shadows of War: A Social History of Silence in the Twentieth Century. Edited by Efrat Ben Ze'ev, Ruth Ginio, and Jay Winter. New York: Cambridge University Press, 2010, 47-67.

Winter, Jay. "Thinking about Silence." Shadows of War: A Social History of Silence in the Twentieth Century. Edited by Efrat Ben Ze'ev, Ruth Ginio, and Jay Winter. New York: Cambridge University Press, 2010, 3-31.

Woodworth, Paddy. "Spain Changes Course: Aznar's Legacy, Zapatero's Prospects." World Policy Journal 21, no. 2 (Summer, 2004): 7-26.

Yehuda, Rachel and Linda M. Bierer, "The Relevance of Epigenetics to PTSD: Implications for the DSM-V." J. Trauma Stress 22, no. 5 (October 2009): 427-434. 
Yehuda, Rachel, Nikolaos P. Daskalakis, Linda M. Bierer, Heather N. Bader, Torsten Klengel, Florian Holsboer, and Elisabeth B. Binder. "Holocaust Exposure Induced Intergenerational Effects on FKBP5 Methylation," J. Biological Psychiatry In Press, Published Online August 12, 2015: 1-9. 